WALDBAU UND WALDÖKOLOGIE DER GEMÄSSIGTEN ZONEN

SILVICULTURE AND FOREST ECOLOGY OF THE TEMPERATE ZONES

Competition mechanisms of native and exotic tree species

\author{
Dissertation \\ zur Erlangung des Doktorgrades \\ der Fakultät für Forstwissenschaften und Waldökologie \\ der Georg-August-Universität Göttingen
}

vorgelegt von

M. Sc.

Heike Kawaletz

geboren in Salzgitter

Göttingen, Dezember 2013 
1. Gutachter: Prof. Dr. Christian Ammer, Göttingen

2. Gutachter: Prof. Dr. Stefan Zerbe, Bozen

Tag der mündlichen Prüfung: 02.08.2013 



\section{Table of contents}

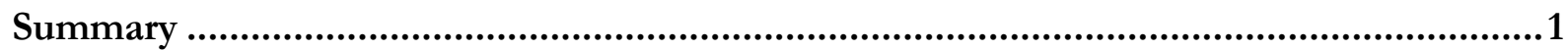

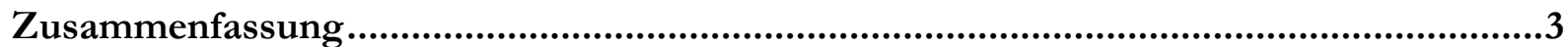

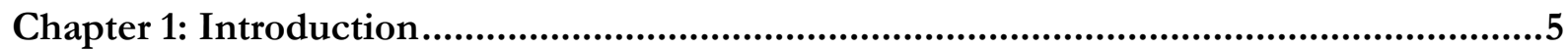

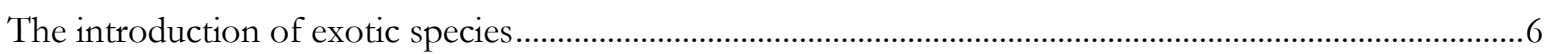

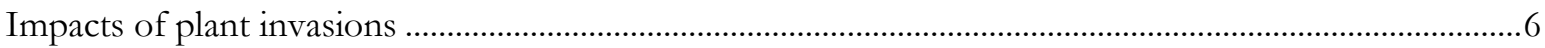

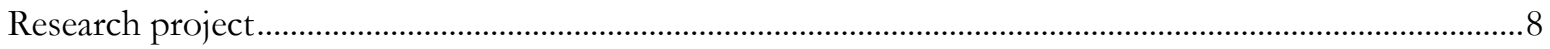

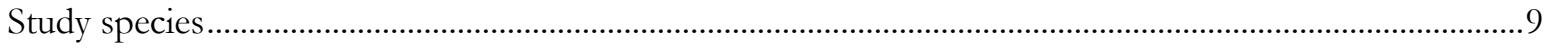

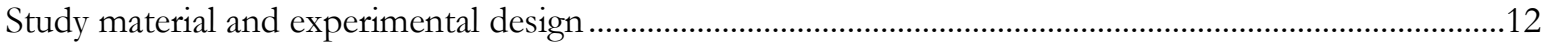

Study objectives and hypotheses ............................................................................................................16

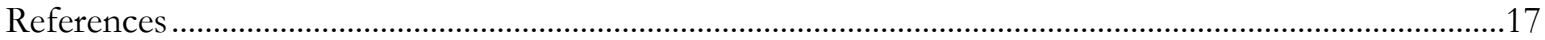

Chapter 2: Pot experiments with woody species - a review ...........................................23

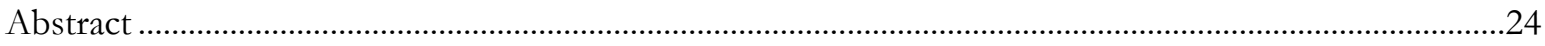

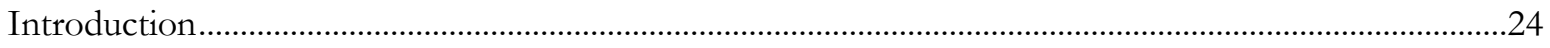

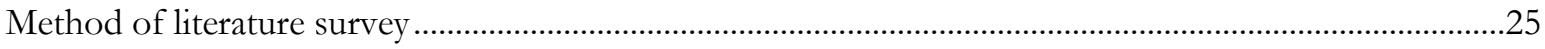

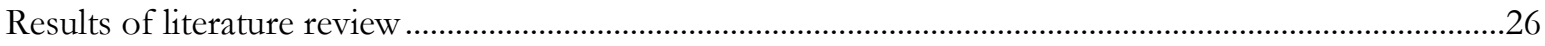

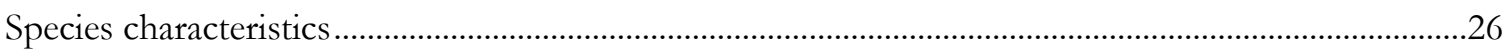

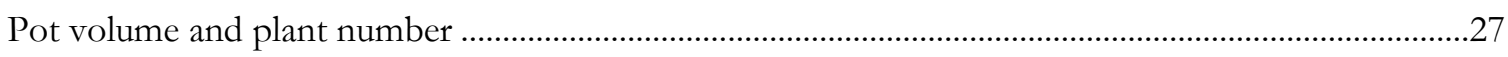

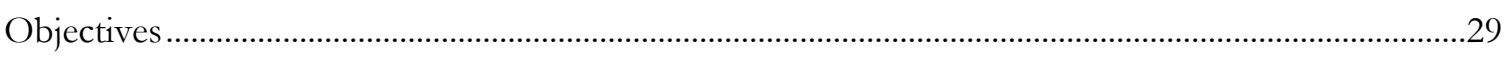

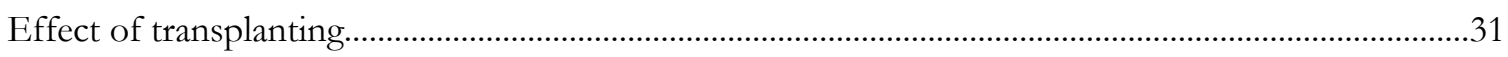

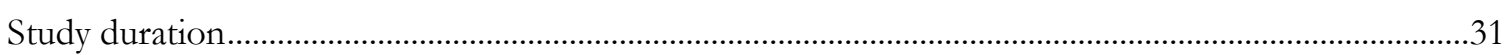

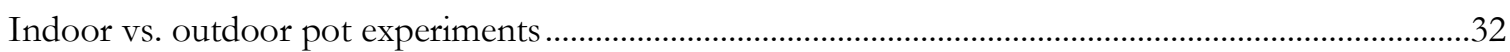

Conclusions for future pot experiments with woody plants.........................................................................32

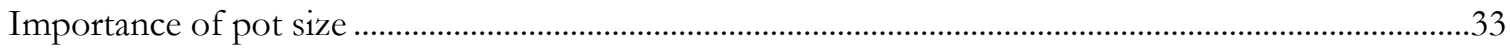

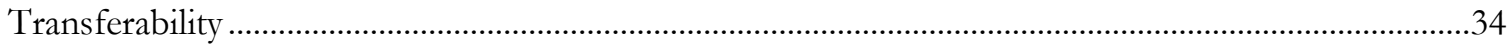

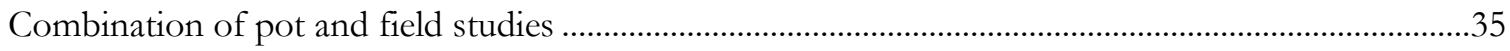

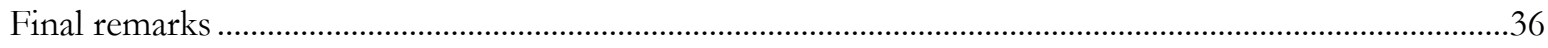

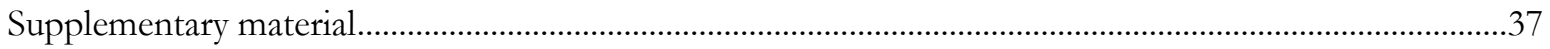

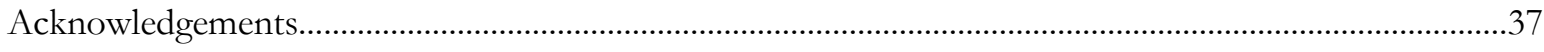

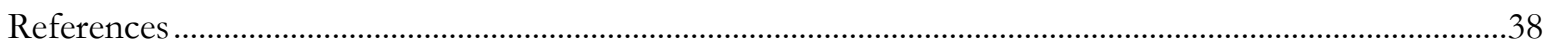

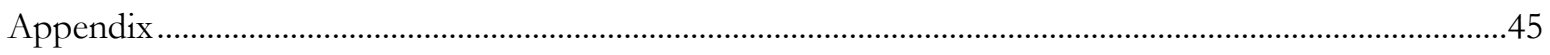


Chapter 3: Exotic tree seedlings are much more competitive than natives but show underyielding when growing together.

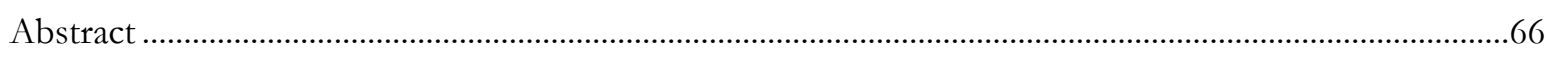

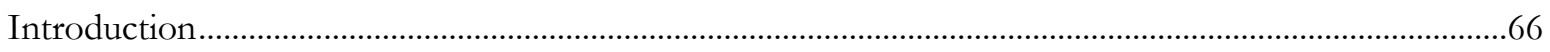

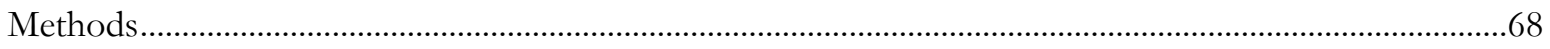

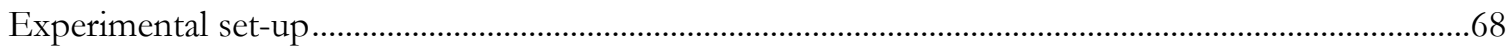

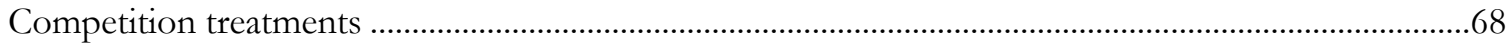

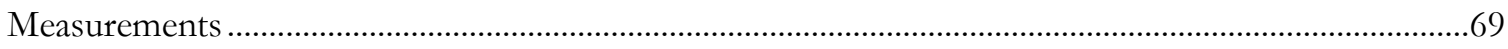

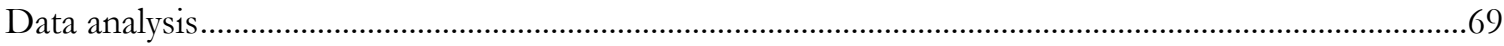

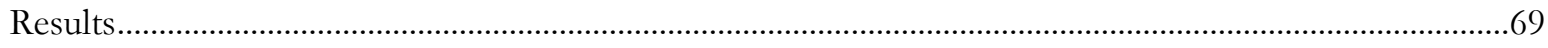

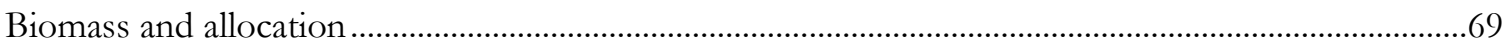

Biomass productivity of monocultures vs. mixtures ……………………............................................

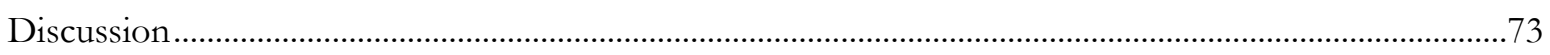

Are exotic species more competitive due to a higher productivity? .........................................................73

Does root competition affect biomass production of the inferior species? ……………………………...73

Do species mixtures produce more biomass than monocultures? ...........................................................

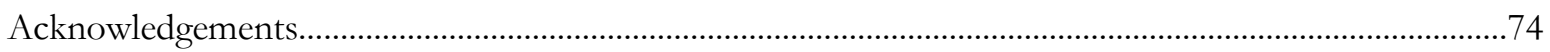

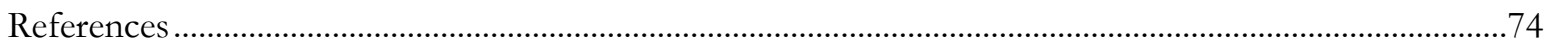

Chapter 4: Back to the roots: how do seedlings of native tree species react to the competition by exotic species? ...................................................................................7

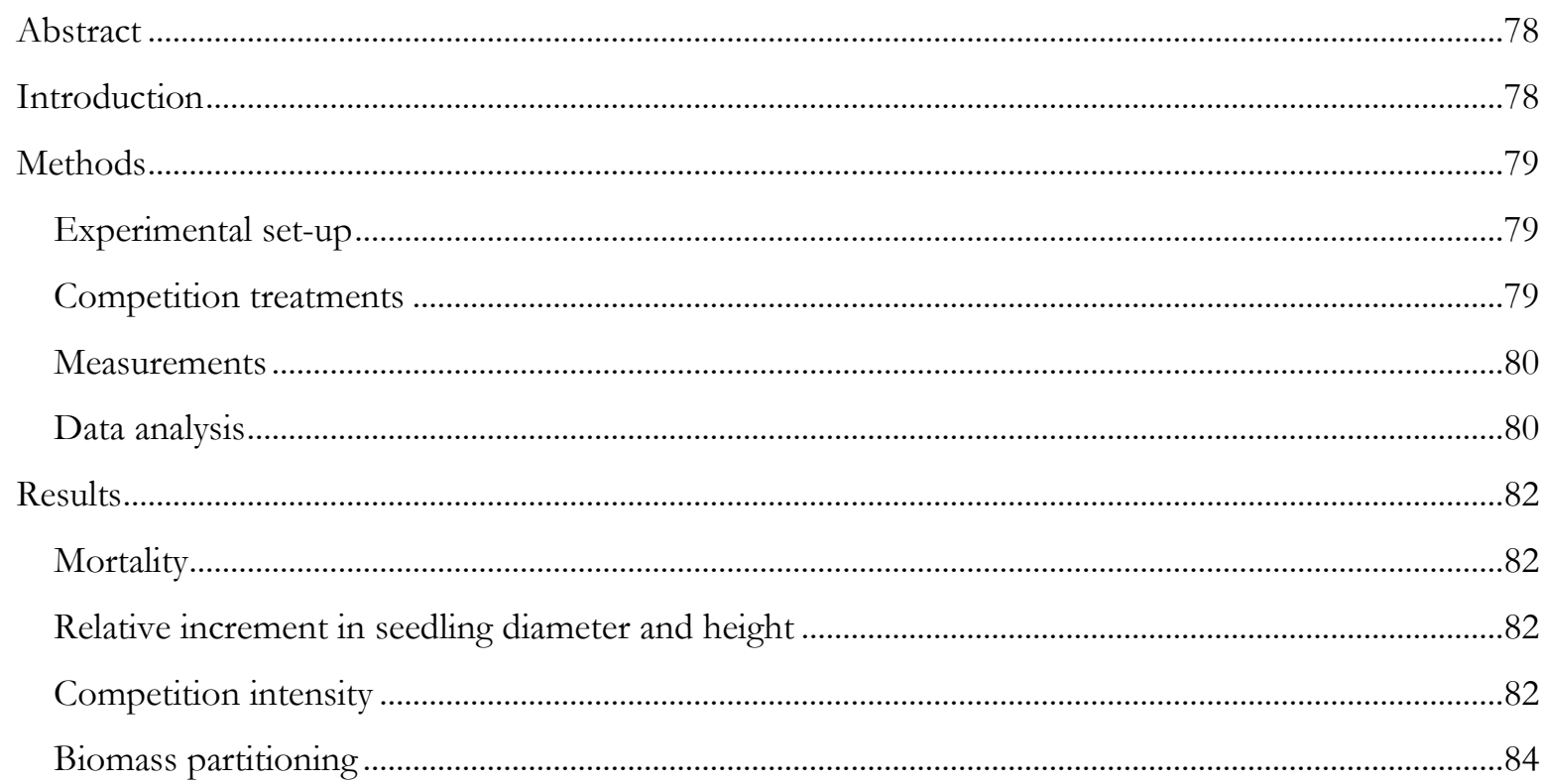




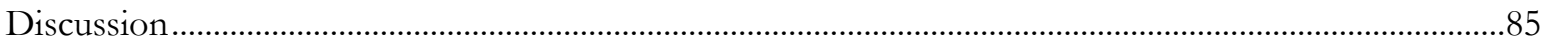

Exotic species are strong competitors in the seedling phase ….........................................................85

Allocation to root biomass as a sign for competitive stress ...............................................................86

Implications for future work on the invasiveness of exotic tree species............................................8

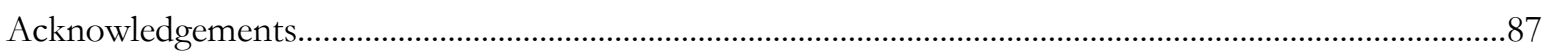

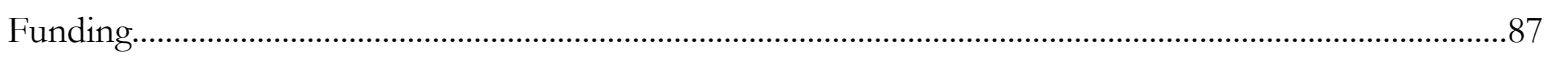

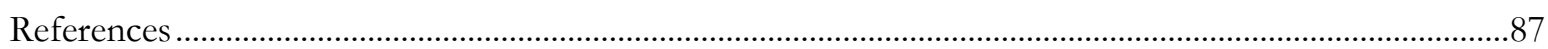

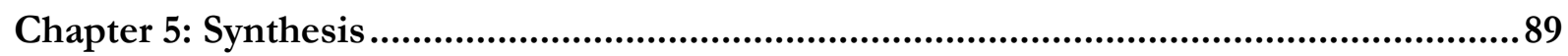

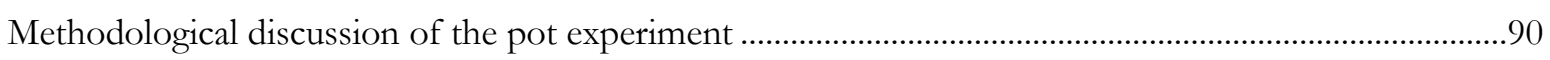

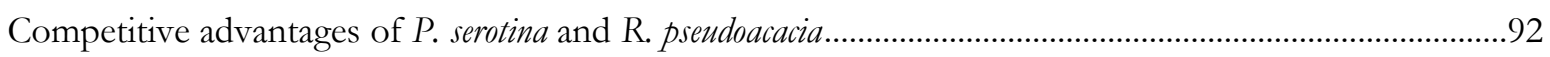

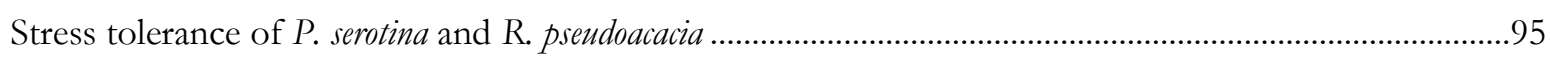

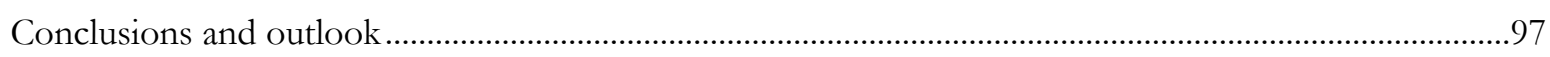

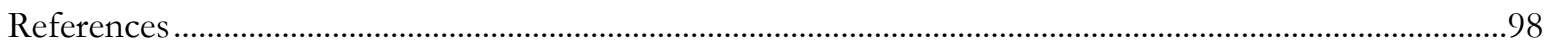

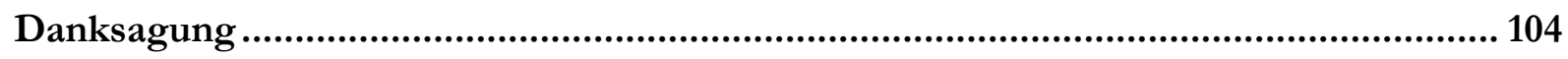

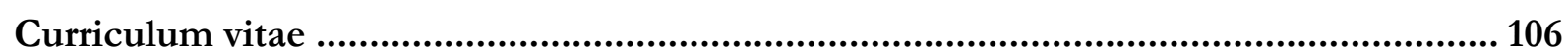

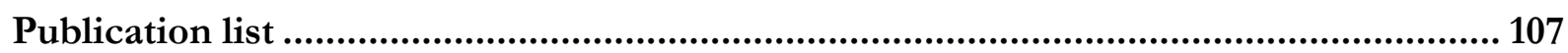




\section{Summary}

The amount of exotic plant species introduced to new regions by humans has considerably increased in the last two centuries. Worldwide, the invasion of exotic species represents an important threat to native biodiversity and ecosystem functions. Several biological traits (e.g., high growth rate and rapid propagation) result in a superior competitiveness of invasive species and often cause changes in natural species composition. Specifying the attributes that turn exotic species into strong competitors may improve the ability to understand and effectively manage plant invasions in the future.

Conducting a pot experiment ensures the investigation of plant interactions under relatively controlled conditions without distracting effects of heterogeneous environmental factors. However, pot experiments with tree species raise more problems in comparison with herbaceous plants due to their longevity and bigger dimensions. This is shown by a comprehensive literature review giving an overview on the practical implementation of pot experiments studying exclusively tree species. It is evident that the advantage of pot experiments is also a disadvantage at the same time: Due to the controlled conditions, pot experiments are always restricted in their ability to imitate natural situations. Thus, the reliability of pot studies for predicting the growth and performance of trees in the field can be problematic. One option to improve the transferability of pot experiments could be to implement additional measurements under natural conditions.

In a pot experiment, I investigated the competition mechanisms due to differences in growth rate, biomass production, and biomass allocation of two native (Quercus robur L., Carpinus betulus L.) and two exotic tree species (Prunus serotina Ehrh., Robinia pseudoacacia L.). One-year-old tree seedlings were planted in different intra- and interspecific, competitive situations with or without the influence of root competition. To determine the competition mechanisms in more detail, I distinguished between root and shoot competition by installing either above- or belowground plastic partitions in the pots. I hypothesized that total biomass production of the exotic tree species is significantly higher compared to the native species resulting in a biomass reduction of Q. robur and C. betulus. Furthermore, I analyzed the effect of belowground competition on native plant performance and biomass allocation patterns according to the 'balanced-growth hypothesis'.

The results supported the assumptions that biomass production of exotic P. serotina and R. psendoacacia is significantly higher, which leads to a strong competitive advantage and to a biomass decrease of the admixed less competitive native species. The competitive pressure of exotic tree seedlings on $Q$. robur and $C$. betulus was largely driven by root competition. The 
exclusion of belowground interactions by partitions led to an increasing biomass production of both native species. Thus, even a limited rooting volume seemed to provide better growing conditions than direct root interactions by invasive competitors. In accordance with the 'balanced-growth hypothesis', Q. robur and C. betulus allocated more biomass towards the roots due to the strong effect of belowground competition by exotic species. The higher proportion of the root fraction was mainly achieved at the expense of leaf and branch biomass.

Furthermore, the results showed a higher biomass production in mixtures of native and exotic tree species than their growth in monocultures would have predicted. Competition was lower for exotic species in mixtures with the less productive $Q$. robur and $C$. betulus compared to the competition in monocultures or in mixture with the other exotic species. Regarding both exotic species, $P$. serotina produced a significantly higher biomass. Nevertheless, $R$. pseudoacacia negatively affected the biomass production of $P$. serotina due to its strong root competition. Accordingly, both highly competitive exotic species inhibited each other's growth and produced less biomass in mixture with each other compared to the respective monocultures.

There is evidence that the strong competitiveness of invasive exotic species is often achieved at the expense of a tolerance to environmental stress. Accordingly, both exotic species had a higher mortality rate in the pot experiment and especially P. serotina seemed to be sensitive to shade, drought, and flooding. Possibly, this weakness could be used to prevent a further spreading of invasive species. 


\section{Zusammenfassung}

Der Anteil an nicht-einheimischen Pflanzenarten (Neophyten), die durch menschlichen Einfluss in neue Gebiete eingebracht worden sind, hat in den letzten zwei Jahrhunderten deutlich zugenommen. Weltweit gefährdet die Invasion von Neophyten beträchtlich die einheimische Biodiversität und Ökosystemfunktionen. Verschiedene biologische Eigenschaften (z.B. hohe Zuwachsrate und schnelle Vermehrung) führen zu einer besseren Konkurrenzfähigkeit von invasiven Arten und verursachen Veränderungen in der natürlichen Artzusammensetzung. Eine genauere Erfassung der Eigenschaften, die Neophyten zu starken Konkurrenten machen, könnte dabei helfen pflanzliche Invasionen besser zu verstehen und zukünftig effektiver zu steuern.

Topfversuche ermöglichen die Untersuchung von Pflanzeninteraktionen unter kontrollierten Bedingungen ohne den schwer kalkulierbaren Einfluss heterogener Umweltfaktoren. Allerdings führen die Langlebigkeit und die größeren Dimensionen von Baumindividuen zu mehr Problemen in Topfversuchen im Vergleich zur Untersuchung krautiger Pflanzen. Aus diesem Grund wurde im Rahmen eines Reviews Literatur ausgewertet, um einen Überblick über die praktische Durchführung von Topfversuchen, die sich ausschließlich mit Baumarten beschäftigen, zu geben. Es ist offensichtlich, dass der Vorteil von Topfversuchen zugleich auch einen Nachteil darstellt: Aufgrund der kontrollierten Bedingungen sind Topfversuche in ihrer Eignung natürliche Gegebenheiten zu imitieren immer eingeschränkt. Die Zuverlässigkeit von Topfversuchen bei der Vorhersage des Baumwachstums unter natürlichen Bedingungen ist daher problematisch. Eine Möglichkeit um die Übertragbarkeit von Topfversuchen zu verbessern, könnte die Durchführung zusätzlicher Felduntersuchungen sein.

In einem Topfversuch wurden die, durch Unterschiede in der Wuchsrate, Biomasseproduktion und Biomasseverteilung bedingten, Konkurrenzmechanismen von zwei einheimischen (Quercus robur L., Carpinus betulus L.) und zwei nicht-einheimischen Baumarten untersucht (Prunus serotina Ehrh., Robinia pseudoacacia L.). Einjährige Jungpflanzen wurden verschiedenen intra- und interspezifischen Konkurrenzbedingungen ausgesetzt, mit oder ohne den Einfluss von Wurzelkonkurrenz. Um die Konkurrenzmechanismen genauer zu bestimmen, wurde zwischen Wurzel- und Sprosskonkurrenz unterschieden, indem entweder ober- oder unterirdische Plastiktrennwände in die Töpfe integriert wurden. Es wurde angenommen, dass die Gesamtbiomasseproduktion der Neophyten im Vergleich zur Biomasseproduktion der einheimischen Baumarten signifikant höher ist und dies zu einer Verringerung der Biomasse von Q. robur und C. betulus führt. Des Weiteren wurde der Einfluss der unterirdischen Konkurrenz auf das Wachstum und die Biomasseverteilung der einheimischen Arten gemäß der , balanced-growth hypothesis‘ untersucht. 
Unsere Ergebnisse bestätigen die Annahmen, dass die Biomasseproduktion der beiden Neophyten P. serotina und R. pseudoacacia signifikant höher ist und dies zu einem großen Konkurrenzvorteil und zu einer Biomassereduktion der beigemischten konkurrenzschwächeren einheimischen Arten führt. Der Konkurrenzdruck auf Q. robur und C. betulus wurde vor allem durch die Wurzelkonkurrenz der nicht-einheimischen Arten verursacht. Die Ausschaltung von unterirdischen Pflanzeninteraktionen durch Trennwände führte somit zu einem Anstieg der Biomasseproduktion der beiden einheimischen Arten. Demzufolge scheint sogar ein begrenztes Wurzelvolumen bessere Wachstumsbedingungen zu bieten als direkter Wurzelkontakt mit invasiven Konkurrenten. In Übereinstimmung mit der ,balanced-growth hypothesis ${ }^{`}$ reagieren Q. robur und C. betulus auf die starke unterirdische Konkurrenz durch die Neophyten, indem sie mehr Biomasse in Richtung der Wurzeln transportieren. Die verstärkte Investition der Pflanzen in die Wurzeln geht vor allem zu Lasten von Blatt- und Astbiomasse.

Außerdem hat sich gezeigt, dass Artenmischungen aus einheimischen und nicht-einheimischen Bäumen mehr Biomasse produzieren, als man anhand des Wachstums dieser Arten in Monokulturen erwartet hätte. Im Vergleich zu Monokulturen oder Mischungen beider Neophyten war der Konkurrenzdruck für P. serotina und R. psendoacacia in Mischungen mit den weniger produktiven einheimischen Baumarten geringer. Bei Betrachtung der beiden nichteinheimischen Arten wird deutlich, dass P. serotina signifikant mehr Biomasse produziert. Trotzdem hat R. pseudoacacia aufgrund der starken Wurzelkonkurrenz einen negativen Einfluss auf die Biomasseproduktion von P. serotina. Wachsen die beiden konkurrenzstarken Neophyten zusammen in einem Topf, produzieren sie weniger Biomasse als in den entsprechenden Monokulturen.

Es gibt Anzeichen dafür, dass die starke Konkurrenzfähigkeit der invasiven Neophyten oftmals zu Lasten ihrer Stresstoleranz geht. Damit einhergehend zeigten die beiden nicht-einheimischen Arten im Topfversuch eine höhere Mortalitätsrate: Vor allem P. serotina scheint zudem empfindlich gegenüber Schatten, Trockenheit und Überflutung zu sein. Möglicherweise könnte diese Schwachstelle der Neophyten genutzt werden, um eine weitere Ausbreitung einzudämmen. 


\section{Chapter}

Introduction 


\section{The introduction of exotic species}

The expansion of exotic species (also referred to as 'introduced', 'non-native', or 'alien' species, etc.) leads to various changes of the natural ecosystems worldwide. By definition, a non-native species occurs outside its native range, which it would not occupy naturally, and has been introduced there by human activities (DAISIE Project 2009). Since the rediscovery of America in 1492, the anthropogenic immigration exceeds by far the natural range expansion of species (Kowarik 2010). About $50 \%$ of the European exotic plant species have been introduced to Europe since 1899 (Lambdon et al. 2008). In Germany, for instance, a number of 450 naturalized exotic plant species, introduced after 1492, is registered. After United Kingdom, Belgium, and Italy, Germany is among the 10 countries with the highest density of naturalized exotic plant species (Lambdon et al. 2008). Out of 2271 exotic plant species introduced to Europe, the majority originates from other European countries (53\%), Africa (36 \%), temperate Asia (34 \%), tropical Asia (25\%), North America (18\%), South America (16\%), and Australasia (3\%) (Lambdon et al. 2008, multiple selections possible for species with native distribution on more than one continent).

The introduction by humans happens either unintended (e.g., by contaminated seeds or via ballast water of ships) or with a certain intention (Kowarik 2010). The respective percentage of species that have been introduced either by purpose or by accident varies among taxonomic groups (Mack et al. 2000): The majority of plant species, for instance, has been introduced deliberately. After Pyšek et al. (2009) the proportion of intentional introductions accounts for $63 \%$ and the unintentional ones for $37 \%$. Non-native plant species introduced prior to 1492 (archeophytes) particularly have agricultural use and include a lot of familiar species such as types of grain, cherry, or apple (Kowarik 2010). After 1492, in contrast, more than half of all exotic plant and tree species in Europe were mainly introduced and cultivated for ornamental and horticultural reasons (Pyšek et al. 2009b) such as Ailanthus altissima (Mill.) Swingle, Impatiens glandulifera Royle, Prunus serotina Ehrh., Robinia psendoacacia L., or Rosa rugosa Thunb. ex Murray amongst others.

\section{Impacts of plant invasions}

Only the fewest organisms succeed in getting to a new place outside their native range. Most of these species are eliminated by various abiotic or biotic agents soon after their arrival (Mack et al. 2000). Out of this finally surviving percentage, again, just a small fraction manages to establish and become naturalized. Accordingly, the majority of exotic species does not cause damages to 
the native environment. However, some of the non-native species are able to spread very rapidly, thereby endanger the natural biodiversity, human health, and economic or esthetic values and, thus, are called invasive species (DAISIE Project 2009). For a variety of British plant species, Williamson and Fitter (1996) developed the 'tens rule' stating that $10 \%$ of imported species appear in the wild, $10 \%$ of those become naturalized, and $10 \%$ of the naturalized species cause economic problems. The term 'invasion' for the spread of exotic species caused by humans was used for the first time by Lehmann (1895). The book 'The ecology of invasions by animals and plants' by Elton (1958) is considered as the first important scientific work on biological invasions (Richardson and Pyšek 2007). Vascular plants are the most intensively explored taxonomic group of all invasive species, and about 400 plant invaders are known to be investigated in case studies all over the world, 80 of them in Europe (Pyšek et al. 2008).

In natural ecosystems, plant invaders can alter important ecological functions such as the fire regime, nutrient cycle, or hydrology and threaten the abundance, growth, and survival of native species (Mack et al. 2000). Biological invasions are regarded as the major threat to biodiversity (Kowarik and Lippe 2007). To date, the mechanisms that lead to the success of some invasive species are not yet completely understood. More information is needed on how invasive species manage to rapidly suppress native species that have been well adapted to regional environmental conditions for a long time (Sax and Brown 2000). Various studies are aimed at determining the characteristics that enable non-native species to invade a new habitat (e.g., Williamson and Fitter 1996b; Alpert et al. 2000; Callaway and Aschehoug 2000; Bray et al. 2003; Closset-Kopp et al. 2007). Rejmanek and Richardson (1996) found attributes of plant-dispersal to be important for a successful invasion by ensuring a fast population growth such as a short juvenile period, frequent seed crops, and small seed mass. Apart from a rapid propagation, a high growth rate, biomass production, and leaf area are other important traits of plant invaders (e.g., Williamson and Fitter 1996b; Pyšek and Richardson 2008; Lamarque et al. 2011). Hufbauer and Torchin (2007) and Lamarque et al. (2011) give an overview of ecological and evolutionary hypotheses applied to explain biological invasions. It is assumed that successful plant invasions result from the interaction between ecosystem invasibility on the one hand and species invasiveness on the other hand (Alpert et al. 2000; Closset-Kopp et al. 2011). Ecosystem invasibility specifies the traits of a new habitat that makes it susceptible to plant invasions. Invasiveness describes the characteristics of exotic species that enable them to invade a new ecosystem. Pyšek et al. (2009a) indicated that an effective invasion depends on a long residence time, in which an exotic species is present in a new habitat, and the level of propagule pressure. Accordingly, the longer the residence time the larger the seed and seedling bank leading to a higher probability of propagation and naturalization (Rejmánek et al. 2005). Another hypothesis refers to the 
advantage of exotic species due to the release from biotic constraints such as herbivores or parasites in their native range (Mack et al. 2000). Thus, they have a competitive advantage compared to native species that are already interacting with a variety of other competitors (Sax and Brown 2000). Another potentially explanation for the success of alien invaders is described by the 'evolution of increased competitive ability (EICA) hypothesis' (Blossey and Nötzold 1995). It proposes that - in case of absent or low enemy pressure - non-native plants often become invasive due to a shift in allocation from defensive mechanisms to growth and reproduction (Rogers and Siemann 2004). Thus, natural selection favors invader genotypes with less defensive but more competitive traits (Bossdorf et al. 2004; Alpert 2006).

In general, competitiveness and invasion of exotic plant species has to be regarded in the context of climate change. It is expected that climate change will lead to changes in competitiveness of exotic plant species. A warmer environment may advance the spread of some exotic species and contemporaneously enhancing the invasibility of ecosystems by disturbing the balanced dynamics maintaining them (Thuiller et al. 2007; Juhász et al. 2009; Benesperi et al. 2012).

\section{Research project}

The precedent study is part of a junior research group called 'BEN - Biodiversity, Ecology and Management in National Parks and Biosphere Reserves'. All three sub-projects work under the project title 'The impact of tree species diversity on tree growth and herb-layer diversity ecological studies and management implications at the biosphere reserve Valle del Ticino'.

The biosphere reserve 'Valle del Ticino' is located in northwestern Italy (Lombardy) near the city of Milan and south of Lago Maggiore. Since the reserve is the largest continuous remnant of woodlands in the Po River plain, it was designated as part of the 'UNESCO Man and Biosphere Programme' as MAB Biosphere Reserve 'Valle del Ticino' in 2002 (UNESCO 2005). The area consists of riparian forests and wetlands along the Ticino River. The natural vegetation is oakhornbeam forest (Querco-Carpinetum), i.e. mixed forest of pedunculate oak (Quercus robur L.) and hornbeam (Carpinus betulus L.), with a considerable proportion of sweet chestnut (Castanea sativa Mill.), conifer (Pinus spp.), poplar (Populus spp.), and black alder (Alnus glutinosa L.) (Boschetti et al. 2007). Nowadays, the forests of the biosphere reserve are affected by the spreading of exotic tree species such as black cherry (Prunus serotina Ehrh.) and black locust (Robinia psendoacacia L.) that have been introduced to the area in the early twentieth century (Annighöfer et al. 2012a). Due to its ability to displace other species, to dominate the understory, and to suppress the regeneration of native species (Verheyen et al. 2007), P. serotina is referred to as an invasive 
species. R. pseudoacacia, as a nitrogen-fixing species, is able to alter soil conditions and species compositions on many sites and, for this reason, is also regarded as invasive (Motta et al. 2009).

Both, forest ecologists as well as nature conservationists are interested in the impacts of exotic tree invaders on the development of native forests. Thus, a closer examination of the reasons for the fast spreading of non-native tree species is required. The aim of our research project is to study the mechanisms leading to an increasing abundance of exotic tree species, to investigate the effects on the native vegetation, and to propose ecologically agreeable methods to prevent a further spreading. The research project is composed of the following three sub-projects:

(1) The first sub-project surveys the forest structure in the biosphere reserve and studies the impact of exotic tree species on the tree and herb layer diversity (André Terwei, Free University of Bozen-Bolzano, Italy).

(2) The second sub-project estimates the aboveground biomass of invasive P. serotina in the biosphere reserve for economic use and tests measures to avoid a further spreading (Peter Annighöfer, Georg-August University of Göttingen, Germany).

(3) In the third sub-project, which will be described in the following, a pot experiment was conducted as a complement to the in-situ studies (1) and (2). In the pot experiment, I investigated the biomass production and growth reactions of four species characterizing the study area: the two native (Q. robur, C. betulus) and the two exotic tree species (P. serotina, R. pseudoacacia). They were planted in different intra- and interspecific, competitive situations with or without the influence of root competition.

\section{Study species}

For the pot experiment, I chose tree species that are typical for the prevalent native and nonnative vegetation of the study area 'Valle del Ticino': pedunculate oak ( $Q$. robur) and hornbeam (C. betulus) as native species, black cherry (P. serotina) and black locust (R. psendoacacia) as exotic species. In the following, the four tree species are introduced:

(1) In Central Europe, pedunculate oak $(Q$. robur $)$ is one of the most frequent deciduous forest tree species and important in both ecological and economic aspects (Roloff et al. 2010). It provides high-quality timber for construction and furniture manufacture (Forestry Compendium 2012a). Pedunculate oak grows under a wide range of different climate conditions and can be found from Ireland and Scandinavia in the north to southern Italy and from the Russian Ural Mountains in the east to northern Spain in the west (Roloff et al. 2010). Due to its ability to 
tolerate even long-term flooding, Q. robur is a typical species in hardwood floodplain forests, e.g., in the biosphere reserve 'Valle del Ticino'/Italy. Pedunculate oak has a high demand for light and is not able to successfully compete with other shade providing species such as Fagus sylvativa L. (Roloff et al. 2010). Oak-dominated forests are often affected by invasion of P. serotina (Starfinger et al. 2003). Vanhellemont et al. (2011) found P. serotina to be predominant when the regeneration of $Q$. robur was hampered (e.g., by herbivory). In contrast, when both species succeed to regenerate, pedunculate oak is able to outcompete $P$. serotina in the long term due to its considerably higher life span. The results showed that the significantly higher biomass production of exotic P. serotina and R. psendoacacia led to a strong competitive advantage, resulting in a biomass decrease of the less competitive native species Q. robur (Kawaletz et al. 2013).

(2) Hornbeam (C. betulus) is a European deciduous tree species with minor economic relevance (Roloff et al. 2010). It can be found from southern Sweden/England in the north to southern Italy and from the Balkans and parts of Russia in the east to the Pyrenees in the west (Forestry Compendium 2012b). Hornbeam is often associated with pedunculate oak (Q. robur) in QuercoCarpinetum forests that can be found on the most fertile soils in temperate Europe (Ellenberg 1988). Similar to Q. robur, biomass production of C. betulus was significantly reduced by the strong competitiveness of P. serotina and R. psendoacacia (Kawaletz et al. 2013).

(3) Black cherry (P. serotina) is a deciduous tree species, which is native to the eastern United States and there the only cherry species of commercial value (Marquis 1990). Whereas large trees with high-quality timber can be found on adequate sites, it is just a small, poorly formed tree on inappropriate sites. Black cherry grows well under a wide range of climatic conditions and on a variety of different soil types. On the Allegheny Plateau of Pennsylvania, New York, and West Virginia, P. serotina occurs on all except for the very wettest and very driest soils (Marquis 1990). It grows very fast in early stages and overtops common associated tree species. In 1623, P. serotina was introduced to France as an ornamental tree (Wein 1930). In the second half of the nineteenth century, foresters tried to produce timber of high commercial value (Kowarik 2010). Unfortunately, P. serotina did not meet the expectations and only formed shrubs or small trees of low timber value (Starfinger 1990). After the failed plantings, black cherry was used to improve the soil quality and for wind and fire prevention in coniferous forests (Kowarik 2010). However, the unexpected strong spreading of P. serotina led to silvicultural problems, e.g., as reported by Ernst (1965) and Wittig (1979). By forming dense thickets, invasive P. serotina is a threat to the native plant diversity and natural regeneration (Starfinger et al. 2003). Henceforward, P. serotina was referred to as a 'pest' (van den Tweel and Eijsackers 1987) and as an 'aggressively spreading species' (Borrmann 1987). Therefore, foresters tried to find measures to avoid a further 
expansion (Starfinger et al. 2003). However, all attempts to fight against black cherry failed. Mechanical control by cutting was ineffective due to its strong resprouting (Annighöfer et al. 2012b). Today, the application of herbicides is not very common in European forests for various reasons such as application effort, efficiency, and pest resistance (Ammer et al. 2011, Annighöfer et al. 2012b). Herbicides do not affect the seed bank of P. serotina, i.e. to prevent regeneration chemical control has to be applied for several successive years (Starfinger et al. 2003). For this and other reasons, chemical control of black cherry is not a promising measure. Another option could be to reduce $P$. serotina biologically by treating its stumps with the pathogenic fungus Chondrostereum purpureum (Pers.: Fr.) Pouzar (De Jong et al. 1990). Despite its effectiveness, the probability that the fungus will affect other Prunus species nearby is high (De Jong et al. 1990; Starfinger 1990). The success of all these measures is hampered due to the ability of black cherry to regenerate from seeds, stumps, and root fragments left in the soil (Starfinger et al. 2003). Silvicultural measures reducing the light availability in the long term by planting shade providers such as F. sylvatica or C. betulus, which is native to the biosphere reserve, could be a promising option to reduce the abundance of the shade intolerant P. serotina (Starfinger et al. 2003).

Several characteristics account for the high abundance and predominance of P. serotina in invaded areas: Black cherry is a pioneer tree, i.e. it has a high growth rate (Kawaletz et al. 2013), flowers and fructifies already after a few years (Kowarik 2010), and has an effective regeneration ability (Pairon et al. 2006). Furthermore, seedlings of P. serotina are able to survive under shady conditions under closed canopies ('Oskar syndrome') and to grow rapidly when light conditions improve (Silvertown 1984; Closset-Kopp et al. 2007). These traits in combination with its ability to form a dense and light reducing canopy impeding regeneration of co-occurring species (Godefroid et al. 2005; Pairon et al. 2006) makes P. serotina a highly competitive invader.

(4) Black locust (R. pseudoacacia) is another invasive exotic tree species causing major difficulties in many European forest ecosystems (Kleinbauer et al. 2010). Black locust was introduced from North America and planted for the first time in France as an ornamental tree between 1601 (DAISIE Project 2009) and 1635 (Wein 1930). In the following years, R. pseudoacacia was planted to control soil erosion and for timber and nectar production (DAISIE Project 2009; Kowarik 2010). To date, R. psendoacacia is still the most widely planted North American tree species in Europe (DAISIE Project 2009; Kowarik 2010), and it is considered to be a suitable species for short rotation coppice (Röhle et al. 2008; Grünewald et al. 2009). Mechanical control measures such as cutting and burning are hardly successful, since black locust is able to resprout vegetatively (DAISIE Project 2009). As the most effective strategy to control a further spreading, Motta et al. (2009) suggest avoiding disturbances (e.g., large gaps), which favor the colonization 
by R. psendoacacia, and waiting for natural suppression by shade providing species. Black locust growths on a wide range of sites in its native and in its non-native range (Huntley 1990; Kleinbauer et al. 2010). Due to its symbiosis with nitrogen-fixing bacteria (Rhizobia) it is able to modify the nutrient cycle, alter soil conditions and change species communities on many sites (Rice et al. 2004; Motta et al. 2009). By increasing the nitrogen content in the soil, black locust facilitates the colonization by further exotic plant species (von Holle et al. 2006). After the introduction to a new area, the abundance of R. pseudoacacia increases and the species forms dense stands (Nasir et al. 2005). Besides, flowers and seeds contain robinin that is toxic to humans (DAISIE Project 2009). Similar to P. serotina, also black locust is a pioneer tree characterized by high growth rate, early fructification, and effective regeneration ability by spreading rapidly from stumps and roots, especially after being damaged (Huntley 1990). For these reasons, R. psendoacacia is referred to as an important threat to native forest vegetation in northern Italy (Motta et al. 2009; Benesperi et al. 2012).

\section{Study material and experimental design}

The above and belowground competition between native and non-native tree species was investigated in a pot experiment between April 2010 (experiment begin) and October 2011 (experiment end). The pot experiment was conducted under outdoor conditions in Göttingen, Germany $\left(51^{\circ} 32^{\prime} \mathrm{N} 9^{\circ} 56^{\prime} \mathrm{E}, 170 \mathrm{~m}\right.$ above sea level). The climate is characterized as temperate with an average annual precipitation of $644.9 \mathrm{~mm}$ and most of the rain falling in June $(81.3 \mathrm{~mm})$. The temperature ranges from $4.8^{\circ} \mathrm{C}$ to $13{ }^{\circ} \mathrm{C}$ with a mean annual temperature of about $8.7^{\circ} \mathrm{C}$ (Wetterstation Göttingen 2013).

To ensure comparability with the vegetation of the biosphere reserve 'Valle del Ticino', tree species were used that are typical for the vegetation found in the reserve: pedunculate oak (Q. robur) and hornbeam (C. betulus) as native species, black cherry (P. serotina) and black locust (R. psendoacacia) as exotic species. At the beginning of the experiment all plants were one-year-old and originated from a nursery in Germany (Münchehof, Lower Saxony), where all plants had grown under homogenous conditions. The seedlings were planted into pots (volume $65 \mathrm{l}$, diameter $54 \mathrm{~cm}$, height $33 \mathrm{~cm}$ ) in spring 2010. The pots were filled with fertilized potting soil (Einheitserde- und Humuswerke, Gebr. Patzer GmbH \& Co. KG, Sinntal-Jossa/Germany, type Eurohum $\mathrm{CRH}$ ) above a $5 \mathrm{~cm}$ layer of coarse gravel to improve drainage. I used potting soil to ensure homogeneous substrate and nutrient conditions in all pots. The tree seedlings were watered as needed with all pots receiving the same amount of water. Excess water drained 
through holes in the bottom of the pots. During winter, the pots were arranged close to each other and embedded in foliar litter to prevent frost damage to the roots. All pots were placed randomly on the area to avoid edge effects.

The aim of the study was to investigate the differences between root and shoot competition. Therefore, a modified 'divided pot technique' (Donald 1958; Snaydon 1971; McPhee and Aarssen 2001) was used, i.e. all tree seedlings were distributed according to one of the following competition treatments (Figure 1, Table 1):

(A) no competition (NC), i.e. either above- and belowground partitions were installed to separate all four individuals in the pot (NC4) or only one single tree seedling per pot was planted to provide maximum rooting space without competition (NC1),

(B) aboveground (shoot) competition (SC), i.e. partitions were installed belowground to eliminate root competition,

(C) belowground (root) competition (RC), i.e. partitions were installed aboveground to eliminate shoot competition,

(D) full competition (FC), i.e. with no partitions at all.

The partitions were made of white rigid PVC sheets. White aboveground partitions reflected the sunlight and thus leveled the light conditions on all four sections of the pot. The aboveground partitions were $1 \mathrm{~m}$ in height. The belowground partitions were fitted to the pot's shape in order to completely isolate the plants in the four compartments.

Four tree seedlings were planted per pot, except for pots containing only one plant (NC1). All plants were arranged in eleven different species combinations of which four were monocultures of Q. robur, C. betulus, R. pseudoacacia, and P. serotina, and seven were species mixtures: (1) Q. robur with C. betulus, (2) R.psendoacacia with P. serotina, (3) Q. robur with R. psendoacacia, (4) Q. robur with P. serotina, (5) C. betulus with R. psendoacacia, (6) C. betulus with P. serotina, and (7) all four species together. Each plant had an available rooting capacity of at least one fourth of the pot volume. The seedlings were planted in the centre of each of the four compartments to ensure that the distance between all individuals as well as to the edge of the pot and the partitions was the same. 

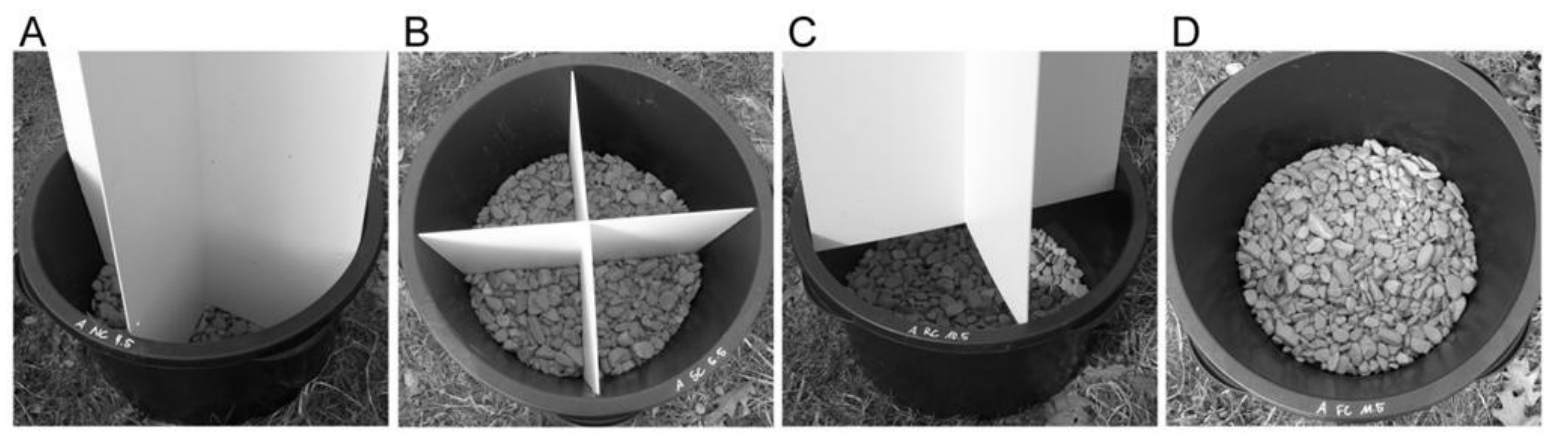

Fig. 1 Set-up of the four different competition treatments: $A=$ no competition (NC4), B = shoot competition (SC), $\mathrm{C}=$ root competition (RC), and $\mathrm{D}=$ full competition (FC) and no competition (NC1), respectively.

As I was able to observe, SC had no significant effect on tree growth in the experiment. However, if the two treatments in which the seedlings were exposed to root competition (i.e. RC and FC) were pooled and compared with the treatment excluding root competition (i.e. SC), a significant effect of root competition was found. In the following, I therefore contrast 'root competition' ( $\mathrm{RC}$ ) with 'no root competition' ( $\mathrm{nRC}$ ). Additionally, there was a high mortality among plants in the NC treatment (see chapter 5 for further explanations). Thus, the entire NC treatment remained unconsidered in the data analyses. Furthermore, all pots with dead seedlings had to be excluded from further analyses, since even only one dead plant per pot would have changed the competitive situation compared to those pots containing four plants. This drastically reduced the number of pots from 752 to 201. At the end of the experiment, all plants were harvested resulting in a total of $\mathrm{n}=804$ trees, of which $\mathrm{n}=246$ were Q. robur, $\mathrm{n}=240$ were C. betulus, $\mathrm{n}=188$ were $\mathrm{R}$. pseudoacacia, and $\mathrm{n}=130$ were $P$. serotina seedlings. The amount of replicates per species mixture in the different competition treatments at the beginning and at the end of the experiment are shown in Table 1. 
Table 1 Amount of plants and pots per mixture type and competition treatment at the beginning and at the end of the pot experiment. Mortality reduced the amount of replicates. If not specified, all pots contained four plants. $\mathrm{NC}=$ no competition, $\mathrm{SC}=$ shoot competition, $\mathrm{RC}=$ root competition, $\mathrm{nRC}=$ no root competition, $\mathrm{FC}=$ full competition.

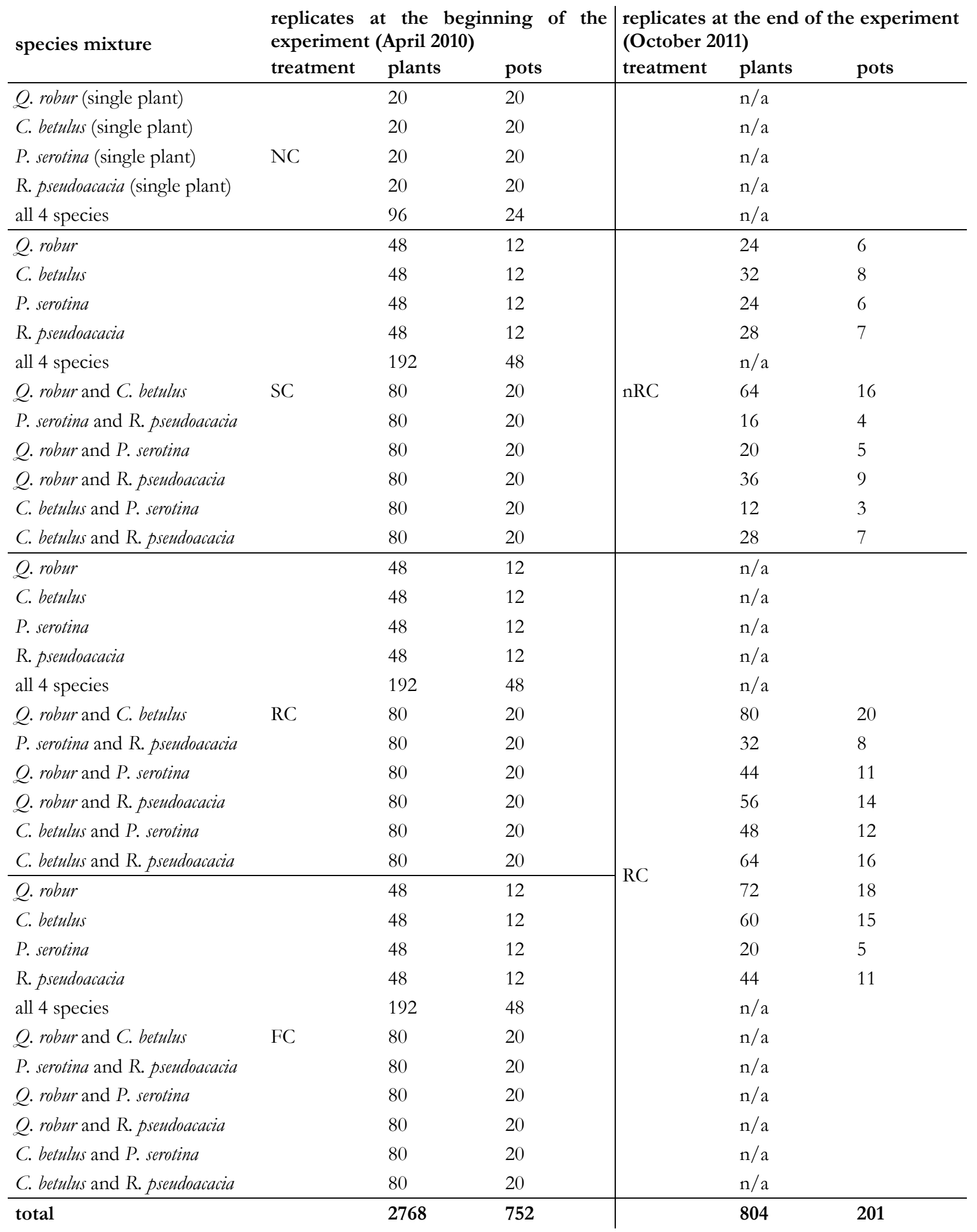




\section{Study objectives and hypotheses}

The invasion of new areas by non-native species often leads to suppression of the native species as it actually happens in the biosphere reserve 'Valle del Ticino' due to further spreading of the exotic trees P. serotina and R. pseudoacacia (Furlanetto et al. 2007; Annighöfer et al. 2012a). The investigations of the overall project were not restricted to field measurements, but were accompanied by a pot experiment with seedlings of the same species. The present study aimed to identify the mechanisms that affect the competition between native and exotic tree species. Under the relatively controlled conditions of the pot experiment, physiological traits of native and non-native trees were compared. This sub-project investigated the competition effects of exotic tree species on the native ones.

At first, chapter 2 gives a literature overview of pot experiments studying exclusively tree species. In pot experiments, the larger dimensions and longevity of tree species raise more difficulties in comparison to the investigation of small-sized and short-living herbaceous plants. There are numerous ways to design pot experiments by varying the parameters such as pot size, soil substrate, plant origin, or plant age. The aim of the literature review was to gather information on the correct implementation of pot experiments with woody species for the present and for future studies. The conception of pot experiments as a complement to field measurements was analyzed by reviewing 93 studies published during 1936 and 2013.

In chapter 3, I compared the biomass production of native Q. robur and C. betulus with exotic P. serotina and R. pseudoacacia. The following hypotheses were tested i) that total biomass production of the exotic tree species is higher than that of the native ones leading to a higher competitiveness of the exotics and ii) that the exclusion of belowground interactions has a positive effect on the biomass production of the less competitive (inferior) species $Q$. robur and C. betulus. Furthermore, I analyzed iii) if the biomass production of species mixtures is higher in comparison to the respective monocultures due to complementarity effects and the strength of competitors.

In chapter 4, I focused on the biomass allocation patterns of native and exotic tree species in terms of competition. Competition affects the resource availability of interacting plants. As predicted by the 'balanced-growth hypothesis', plants allocate biomass preferentially to those compartments, which are involved in the acquisition of the primarily limiting resource. Higher biomass allocation to one compartment is achieved at the expense of other plant organs. According to the 'balanced-growth hypothesis', I tested the biomass partitioning to root and aboveground fractions in case of belowground competition. 


\section{References}

Alpert P., Bone E., Holzapfel C. (2000): Invasiveness, invasibility and the role of environmental stress in the spread of non-native plants. Perspect Plant Ecol Evol Syst 3: 52-66.

Alpert P. (2006): The advantages and disadvantages of being introduced. Biol Invasions 8: $1523-1534$.

Ammer C., Balandier P., Bentsen N.S., Coll L., Löf M. (2011): Forest vegetation management under debate: an introduction. Eur J Forest Res 130: 1-5.

Annighöfer P., Mölder I., Zerbe S., Kawaletz H., Terwei A., Ammer C. (2012a): Biomass functions for the two alien tree species Prunus serotina Ehrh. and Robinia psendoacacia L. in floodplain forests of Northern Italy. Eur J Forest Res 131: 1619-1635.

Annighöfer P., Schall P., Kawaletz H., Mölder I., Terwei A., Zerbe S., Ammer C. (2012b): Vegetative growth response of black cherry (Prunus serotina) to different mechanical control methods in a biosphere reserve. Can J For Res 42: 2037-2051.

Benesperi R., Giuliani C., Zanetti S., Gennai M., Lippi M. M., Guidi T., Nascimbene J., Foggi B. (2012): Forest plant diversity is threatened by Robinia pseudoacacia (black-locust) invasion. Biodivers Conserv 21: 3555-3568.

Blossey B., Nötzold R. (1995): Evolution of increased competitive ability in invasive nonindigenous plants: a hypothesis. J Ecol 83: 887-889.

Borrmann K. (1987): Einbürgerung, Ausbreitung und Vorkommen der Späten Traubenkirsche (Padus serotina Borkh.) in der Oberförsterei Lütkenhagen (Kreis Neustrelitz). Botanischer Rundbrief für den Bezirk Neubrandenburg 19: 13-18.

Boschetti M., Boschetti L., Oliveri S., Casati L., Canova I. (2007): Tree species mapping with Airborne hyper-spectral MIVIS data: the Ticino Park study case. Int J of Remote Sensing 28: $1251-1261$.

Bossdorf O., Prati D., Auge H., Schmid B. (2004): Reduced competitive ability in an invasive plant. Ecol Lett 7: 346-353.

Bray S., Kitajima K., Sylvia D. (2003): Mycorrhizae differentially alter growth, physiology, and competitive ability of an invasive shrub. Ecol Appl 13: 565-574.

Callaway R., Aschehoug E. (2000): Invasive plants versus their new and old neighbors: a mechanism for exotic invasion. Science 290: 521-523. 
Closset-Kopp D., Chabrerie O., Valentin B., Delachapelle H., Decocq G. (2007): When Oskar meets Alice: Does a lack of trade-off in $\mathrm{r} / \mathrm{K}$-strategies make Prunus serotina a successful invader of European forests? For Ecol Manag 247: 120-130.

Closset-Kopp D., Saguez R., Decocq G. (2011): Differential growth patterns and fitness may explain contrasted performances of the invasive Prunus serotina in its exotic range. Biol Invasions 13: 1341-1355.

DAISIE Project (2009): Handbook of alien species in Europe. Springer, New York.

De Jong M. D., Scheepens P. C., Zadoks J. C. (1990): Risk analysis for biological control: a dutch case study in biocontrol of Prunus serotina by the fungus Chondrostereum purpureum. Plant Disease 74: 189-194.

Donald C. (1958): The interaction of competition for light and for nutrients. Aust J Agric Res 9: $421-435$.

Ellenberg H. (1988): Vegetation ecology of Central Europe, 4th ed. Cambridge Univ. Press, Cambridge.

Elton C. S. (1958): The ecology of invasions by animals and plants. Methuen, London.

Ernst K. (1965): Späte Traubenkirsche und Traubenholunder. Berliner Naturscbutz̧blätter 26: 4-11.

Forestry Compendium (2012a): Quercus robur. http://han.sub.uni-goettingen.de/han/ ForestryCompendium/www.cabi.org/fc/?compid $=2 \& d s i d=46574 \&$ loadmodule $=$ datasheet \&page $=2147 \&$ site $=163$. Accessed 11 Mar 2013.

Forestry Compendium (2012b): Carpinus betulus. http://han.sub.uni-goettingen.de/han/ ForestryCompendium/www.cabi.org/fc/?compid=2\&dsid=13607\&loadmodule $=$ datasheet \&page $=2147 \&$ site $=163$. Accessed 11 Mar 2013.

Furlanetto D., Hildebrand L., Lanticina M., Manfredi M., Parco V., Pozzi S., Trotti F., Vailati A. M. (2007): Ticino 21 - Primo rapporto sullo stato dell'ambiente del Parco del Ticino.

Godefroid S., Phartyal S., Weyembergh G., Koedam N. (2005): Ecological factors controlling the abundance of non-native invasive black cherry (Prunus serotina) in deciduous forest understory in Belgium. For Ecol Manag 210: 91-105.

Grünewald H., Böhm C., Quinkenstein A., Grundmann P., Eberts J., Wühlisch G. (2009): Robinia psendoacacia L.: A lesser known tree species for biomass production. Bioenerg Res 2: 123-133. 
Hufbauer R. A., Torchin M. E. (2007): Integrating ecological and evolutionary theory of biological invasions. In: Nentwig W. (ed) Biological Invasions. Springer, Berlin, Heidelberg, p. 79-96.

Huntley J. (1990): Robinia psendoacacia L. - Black locust. In: Burns R., Honkala B. (eds) Silvics of North America: Volume 2: Hardwoods. United States Government Printing, Washington, p. $755-761$.

Juhász M., Bagi I., Csintalan Z. (2009): The critical effect of drought stress on the invading features of bird cherry (Prunus serotina Ehrh.) during dispersion stage on a sand-dune area in Hungary. Cereal Res Commun 37: 553-556.

Kawaletz H., Mölder I., Zerbe S., Annighöfer P., Terwei A., Ammer C. (2013): Exotic tree seedlings are much more competitive than natives but show underyielding when growing together. J Plant Ecol 6 (4): 305-315.

Kleinbauer I., Dullinger S., Peterseil J., Essl F. (2010): Climate change might drive the invasive tree Robinia psendacacia into nature reserves and endangered habitats. Biol Conserv 143: 382-390.

Kowarik I. (2010): Biologische Invasionen. Ulmer, Stuttgart.

Kowarik I., von Lippe M. (2007): Pathways in plant invasions. In: Nentwig W. (ed) Biological Invasions. Springer Berlin, p. 29-47.

Lamarque L. J., Delzon S., Lortie C.J. (2011): Tree invasions: a comparative test of the dominant hypotheses and functional traits. Biol Invasions 13: 1969-1989.

Lambdon P. W., Pyšek P., Basnou C., Hejda M, Arianoutsou M., Essl F. (2008): Alien flora of Europe: species diversity, temporal trends, geographical patterns and research needs. Preslia 80: 101-149.

Lehmann E. (1895): Flora von Polnisch-Livland. 9. Die advenen Florenelemente (Synanthropen) und ihre Verbreitung durch den Menschen und seine Transportmittel (Schiffe und Eisenbahnen). Arch $f$ Naturkde Liv-, Est-u Kurlands Ser Biol 11: 100-119.

Mack R., Simberloff D., Lonsdale W., Evans H., Clout M, Bazzaz F. A. (2000): Biotic invasions: causes, epidemiology, global consequences, and control. Ecol Appl 10: 689-710.

Marquis D. (1990): Prunus serotina Ehrh. - Black cherry. In: Burns R., Honkala B. (eds) Silvics of North America: Volume 2: Hardwoods. United States Government Printing, Washington, p. 594-604. 
McPhee C. S., Aarssen L. W. (2001): The separation of above- and below-ground competition in plants a review and critique of methodology. Plant Ecol 152: 119-136.

Motta R., Nola P., Berretti R. (2009): The rise and fall of the black locust (Robinia psendoacacia L.) in the "Siro Negri" Forest Reserve (Lombardy, Italy): lessons learned and future uncertainties. Ann For Sci 66: 410-410.

Nasir H., Iqbal Z., Hiradate S., Fujii Y. (2005): Allelopathic potential of Robinia psendo-acacia L. JChem Ecol 31: 2179-2192.

Pairon M., Chabrerie O., Casado C. M., Jacquemart A. L. (2006): Sexual regeneration traits linked to black cherry (Prunus serotina Ehrh.) invasiveness. Acta Oecol 30: 238-247.

Pyšek P., Křivánek M., Jarošík V. (2009a): Planting intensity, residence time, and species traits determine invasion success of alien woody species. Ecology 90: 2734-2744.

Pyšek P., Lambdon P. W., Arianoutsou M., Kühn I., Pino J, Winter M. (2009b): Alien vascular plants of Europe. DAISIE, Handbook of alien species in Europe. Springer Netherlands, Dordrecht, p. 43-61.

Pyšek P., Richardson D. M. (2008): Traits associated with invasiveness in alien plants: Where do I stand? Biol Invasions 193: 97-125.

Pyšek P., Richardson D. M., Pergl J., Jarosik V., Sixtova Z., Weber E. (2008): Geographical and taxonomic biases in invasion ecology. Trends Ecol Evol 23: 237-244.

Rejmánek M., Richardson D. M. (1996): What attributes make some plant species more invasive? Ecology 77: 1655-1661.

Rejmánek M., Richardson D. M., Higgins S. I., Pitcairn M. J., Grottkopp E. (2005): Ecology of invasive plants: state of the art. In: Mooney H. A., Mack R. N., McNeely J. A., Neville L. E., Schei P. J., Waage J. K. (eds) Invasive alien species: searching for solutions. Island Press, Washington, D.C., p. 104-161.

Rice S., Westerman B., Federici R. (2004): Impacts of the exotic, nitrogen-fixing black locust (Robinia pseudoacacia) on nitrogen-cycling in a pine-oak ecosystem. Plant Ecol 174: 97-107.

Richardson D. M., Pyšek P. (2007): Elton, C. S. 1958: The ecology of invasions by animals and plants. London: Methuen. Prog in Phys Geogr 31: 659-666.

Rogers W.E., Siemann E. (2004): Invasive ecotypes tolerate herbivory more effectively than native ecotypes of the Chinese tallow tree Sapium sebiferum. J Appl Ecol 41: 561-570. 
Röhle H., Böcker L., Feger K.H., Petzold R., Wolf H., Ali W. (2008): Anlage und Ertragsaussichten von Kurzumtriebsplantagen in Ostdeutschland - Establishment and expected yield of short-term rotation plantations in Eastern Germany. Schweiz Z Forstwes 159: 133-139.

Roloff A., Weisgerber H., Lang U., Stimm B. (2010): Bäume Mitteleuropas: Von Aspe bis Zirbelkiefer. Mit den Porträts aller Bäume des Jahres von 1989 bis 2010. Wiley-VCH, Weinheim.

Sax D., Brown J. (2000): The paradox of invasion. Glob Ecol Biogeogr 9: 363-371.

Silvertown J.W. (1984): Introduction to plant population ecology. Longman, London.

Snaydon R.W. (1971): An analysis of competition between plants of Trifolium repens L. populations collected from contrasting soils. J Appl Ecol 8: 687-697.

Starfinger U (1990): Die Einbürgerung der Spätblühenden Traubenkirsche (Prunus serotina Ehrh.) in Mitteleuropa. Technische Universität Berlin.

Starfinger U., Kowarik I., Rode M., Schepker H. (2003): From desirable ornamental plant to pest to accepted addition to the flora? - The perception of an alien tree species through the centuries. Biol Invasions 5: 323-335.

Thuiller W., Richardson D.M., Midgley G.F. (2007): Will climate change promote alien plant invasions? In: Nentwig W. (ed) Biological Invasions. Springer, Berlin, Heidelberg, p. 197-211.

UNESCO (2005): MAB Biosphere Reserves Directory. Biosphere Reserve Information, Italy Valle del Ticino. http://www.unesco.org/mabdb/br/brdir/directory/biores.asp? mode $=$ all\&code $=I T A+06$. Accessed 8 Mar 2013.

van den Tweel P., Eijsackers H. (1987): Black cherry, a pioneer species or "forest pest". Proc Roy Dutch Acad Sci 90: 59-66.

Vanhellemont M., Baeten L., Verbeeck H., Hermy M., Verheyen K. (2011): Long-term scenarios of the invasive black cherry in pine-oak forest: Impact of regeneration success. Acta Oecologica 37: 203-211.

Verheyen K,. Vanhellemont M., Stock T., Hermy M. (2007): Predicting patterns of invasion by black cherry (Prunus serotina Ehrh.) in Flanders (Belgium) and its impact on the forest understorey community. Divers Distrib 13: 487-497. 
von Holle B., Joseph K.A., Largay E.F., Lohnes R.G. (2006): Facilitations between the introduced nitrogen-fixing tree, Robinia pseudoacacia, and nonnative plant species in the glacial outwash upland ecosystem of Cape Cod, MA. Biodivers Conserv 15: 2197-2215.

Wein K. (1930): Die erste Einführung nordamerikanischer Gehölze in Europa, Teil 1. Mitt Deutsch Dendr Ges 42: 137-163.

Wetterstation Göttingen (2013): http://www.wetterstation-goettingen.de/. Accessed 29 Jan 2013.

Williamson M.H., Fitter A. (1996a): The varying success of invaders. Ecology 77: 1661-1666.

Williamson M.H., Fitter A. (1996b): The characters of successful invaders. Biol Conserv 78: 163-170.

Wittig R. (1979): Verbreitung, Vergesellschaftung und Status der Spätblühenden Traubenkirsche (Prunus serotina Ehrh., Rosaceae) in der Westfälischen Bucht. Natur und Heimat 39: 48-52. 


\section{Chapter}

\section{Pot experiments with woody species}

- a review

H. Kawaletz, I. Mölder, P. Annighöfer, A. Terwei, S. Zerbe, C. Ammer revised version submitted to Forestry 


\title{
Pot experiments with woody species - a review
}

\author{
H. Kawaletz, I. Mölder, P. Annighöfer, A. Terwei, S. Zerbe, C. Ammer
}

\begin{abstract}
Pot experiments, as a complement to field measurements, allow the investigation of plants under controlled conditions without distracting effects of heterogeneous environmental factors. Due to their longevity and bigger dimensions, pot experiments with tree species raise more problems compared to studies with herbaceous plants. In the present literature review, we analyze 93 studies on pot experiments with woody species and give an overview of their practical implementation. The literature review showed that various factors have to be taken into account for providing good growing conditions in pot experiments, e.g. pot size, substrate, plant age and origin, or transplanting effects. The transferability of experimental results to natural conditions is limited and could be improved by implementing additional measurements under natural conditions. Due to the lack of information on the experimental set-up, an evaluation on the quality of pot experiments was hardly possible. Information on the appropriateness of the methodology should be provided that can be used for future pot experiments.
\end{abstract}

\section{Introduction}

The understanding of plant responses to environmental conditions and their interactions is a central object of plant ecology. However, studying interactions and responses of plants in the field often imposes several logistic and analytical constraints due to the complexity of natural plant communities (Gibson et al. 1999). Apart from the heterogeneous environmental conditions (e.g., light, soil properties), species in-situ vary in size, age, and abundance. As a complement to in-situ studies, pot experiments have the advantage to allow direct measurements under controlled conditions without the influence of distracting biotic and abiotic factors (Passioura 2006; Haase 2009; Kohout et al. 2011). For instance, pot experiments are advantageous in studying the impact of root and shoot competition in species mixtures. In such studies, it may be interesting to separate above- from belowground competition for identifying which type of competition has a greater impact on plant growth (McPhee and Aarssen 2001). However, the assessment of belowground interactions under field conditions is difficult in 
comparison with pot experiments. The latter allow destructive harvests to quantify root productivity and allocation that would be hardly feasible in natural stands (Haase 2009).

There are several literature reviews (e.g., Gibson et al. 1999; Poorter et al. 2012a; Poorter et al. 2012b) giving an overview on pot experiments. However, our literature research revealed that pot experiments have mostly been focusing on herbaceous plants, whereas the research with woody forest species is usually conducted in-situ. The underrepresentation of forest tree species in pot experiments may be due to the fact that the examination of woody species implicates more problems than the study of short-living herbaceous plants. The longevity and higher dimensions of tree species, for instance, result in higher financial and material expenses. Due to the limited rooting capacities, pot experiments cannot cover the whole life span of long-living woody species, so the experiments are restricted to early stages of seedling and sapling growth (Mousseau and Saugier 1992). Since the results of pot studies with grasses and other perennial species are hardly transferable to tree species, the issue of pot experiments with woody species therefore needs further analyses. The purpose of the present review is to gather information on the special growing conditions of trees in pots and the requirements for pot experiments if woody species are taken into account. Thus, we are aiming at providing methodological recommendations which may be useful for planning future pot experiments with woody species. In planning a pot experiment many different aspects have to be taken into consideration. In the following, we give an overview of how these aspects were addressed in the reviewed studies.

\section{Method of literature survey}

We surveyed 93 studies on pot experiments with woody species published in a great variety of peer-reviewed scientific journals between 1936 and 2013 (Fig. 1). Relevant literature was searched by using the online database ISI Web of Knowledge. Using online databases did not result in a successful search but many publications were found by browsing references. The used keywords were: "pot experiment", "pot study", or "container experiment" in combination with "trees", "tree species", or "woody species". The literature review was only based on forest trees, i.e. fruit trees were excluded. Despite an intensive literature research, we do not claim to give a complete overview. 


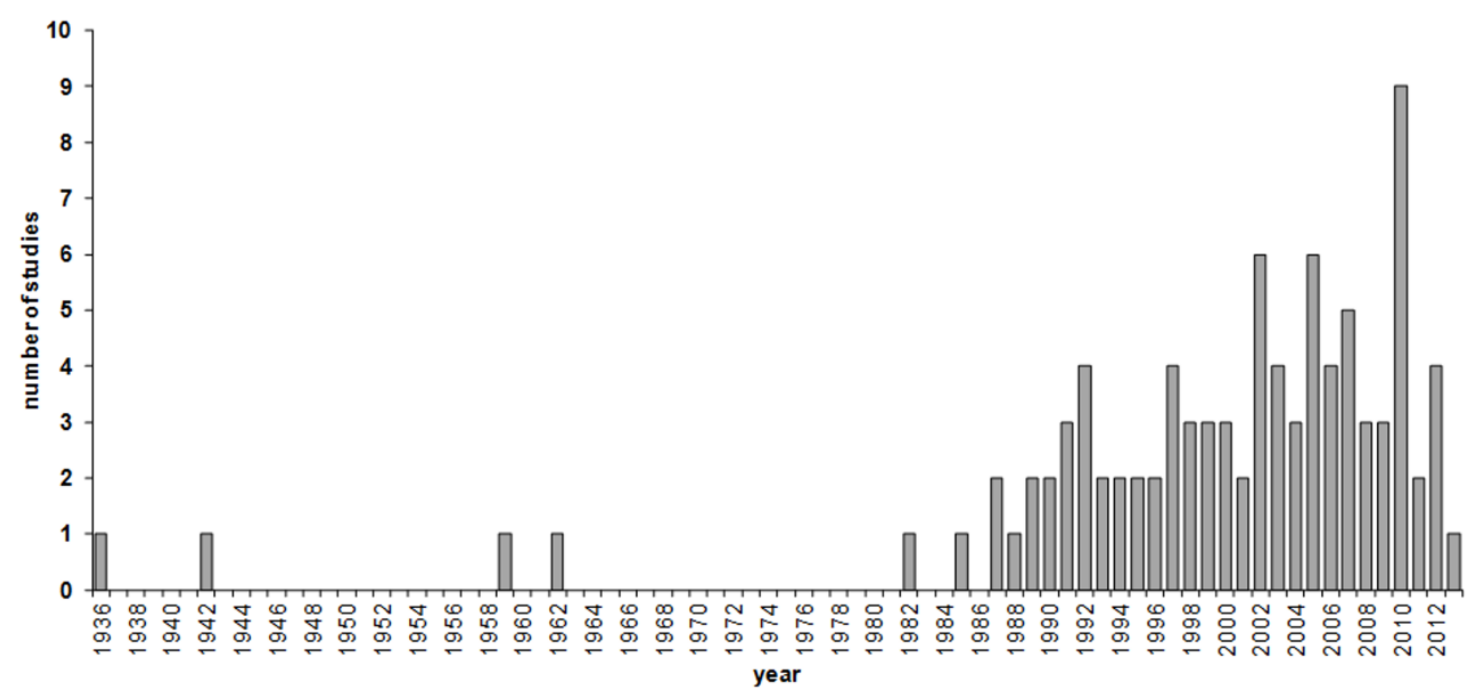

Fig. 1 Amount of publications using pot experiments with woody species between 1936 and 2013.

In accordance with the significant increase of scientific papers in recent years, most of the reviewed pot studies were published during the last 30 years, but they have been used in science for a much longer time (e.g., Kramer 1936).

Unfortunately, especially the older studies rather focused on the results than on the methodology and the implementation of the pot experiment was not described in much detail. Several studies do not provide full information about the experimental set-up (Table S1, appendix). $10.1 \%$ of the studies did not give information on the age of the plants that were used in the pot study. Another $11.8 \%$ did not inform about the pot volume, however, more than half of these studies at least mentioned the diameter of the pot. There was no information on the number of trees planted per pot in $7.5 \%$ of the studies and $3.2 \%$ did not provide information on the study duration. This lack of information made it difficult to analyze the pot experiments properly. Furthermore, exact knowledge of the methodology would help to understand and to reconstruct the experiments.

\section{Results of literature review}

\section{Species characteristics}

Most of the studies investigated one single tree species (34.0\%), but others simultaneously studied up to 20 species (van der Moezel et al. 1991). A lot of different tree species were used for pot experiments. The majority of the studies investigated deciduous trees $(80.4 \%)$ instead of conifers $(19.6 \%)$. For studies that took place in Europe $(45.2 \%)$, the proportion of species belonging to the early successional (pioneer) stage was 21.4, that belonging to the late successional stage was 42.9 , and $31.0 \%$ of the species belonged to an intermediate stage of 
succession. Early successional species have the advantage of growing faster. Thus, results can be expected earlier than for late successional tree species. However, there was not a single study justifying the species choice in this way. In fact, the research objective and study site were much more important for species selection.

In a pot experiment, it is not viable to study adult trees over a long period. Thus, in most cases young trees were used (Mousseau and Saugier 1992). Since intra- and interspecific competition is very important especially in the early growing phase (Haase 2009), pot experiments are an appropriate method to study tree seedlings interactions. Plant age at the beginning of the pot experiment ranged from recently germinated seedlings (McConnaughay et al. 1996; van Hees 1997; Wagner and Dreyer 1997; Heilmeier et al. 2000a; Heilmeier et al. 2000b; Blair 2001; Willoughby et al. 2007; Hata et al. 2010) to 20-year-old trees of natural regeneration (Amundson et al. 1995). Mean plant age was 8.3 months (without outliers). Most studies used either recently sprouted seedlings up to an age of one month (36.6\%) or tree seedlings with an age $>$ one month and $\leq 12$ months $(35.5 \%)$. The youngest seedlings (2.5 months on average) were used in two experiments studying the effects on litter decomposition on germination and initial establishment of very young plants (Hata et al. 2010, Coq et al. 2012, subject area 12 in Fig. 4).

\section{Pot volume and plant number}

Trees were planted in a great variety of pot volumes ranging from $0.0002 \mathrm{~m}^{3}$ (Dehlin et al. 2004) up to $7.1 \mathrm{~m}^{3}$ (Meier 2007); mean pot volume was $0.012 \mathrm{~m}^{3}$ (without outliers). It was noticeable that $11.8 \%$ of the experiments did not give information on pot size at all.

In a meta-analysis, Poorter et al. (2012a) provided a guideline of appropriate pot volume depending on the total dry mass of the plant growing in the pot. They recommended avoiding a total plant dry weight per unit rooting volume greater than $2.0 \mathrm{gL}^{-1}$, under optimal conditions the ratio should be less than $1.0 \mathrm{gL}^{-1}$. For the studies reviewed here, this ratio ranged between $0.107 \mathrm{gL}^{-1}$ and $57.8 \mathrm{gL}^{-1}$, the average value was $9.03 \mathrm{gL}^{-1} \pm \mathrm{SD} 13.07 \mathrm{gL}^{-1}$ (Fig. 2). Approximately $32.6 \%$ of the studies, which were measuring total plant biomass, reached the recommended ratio of less than $2.0 \mathrm{~g}$ dry biomass per liter pot volume.

The plant density in a pot should be comparable to the natural conditions in the forest to allow an undisturbed tree growth. Some studies tried to increase the comparability of the natural and artificial growing conditions by adapting the plant density in pots to the density found in-situ (Groves and Williams 1975; Aerts et al. 1991; White and Holt 2005). In contrast, other studies could artificially elevate the neighbor density to investigate growth response of plants. Osunkoya et al. (2005) and Haase (2009), for instance, analyzed the growth response of tree seedlings on varying competition intensity simulated by means of different seedling densities. 


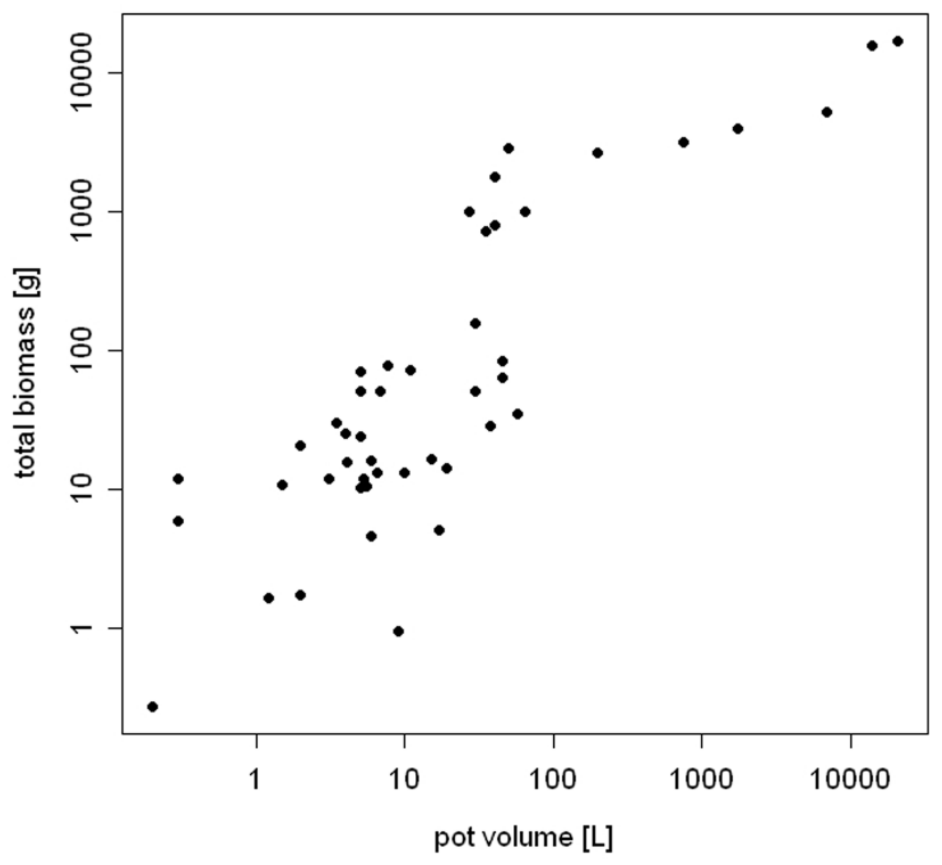

Fig. 2 Mean total plant biomass (dry weight) $[\mathrm{g}]$ per liter $[\mathrm{L}]$ pot volume as reported in the reviewed literature (57 studies that provided the required information).

In most studies (55.9\%) just one single tree seedlings was planted per pot. However, studies that planted one individual per pot did not use exclusively small pot volumes. Used pot sizes in studies with one plant per pot varied considerably and ranged from $0.00025 \mathrm{~m}^{3}$ to $0.057 \mathrm{~m}^{3}$. In general, no relationship could be detected between the number of individuals per pot and pot volume (Fig. 3).
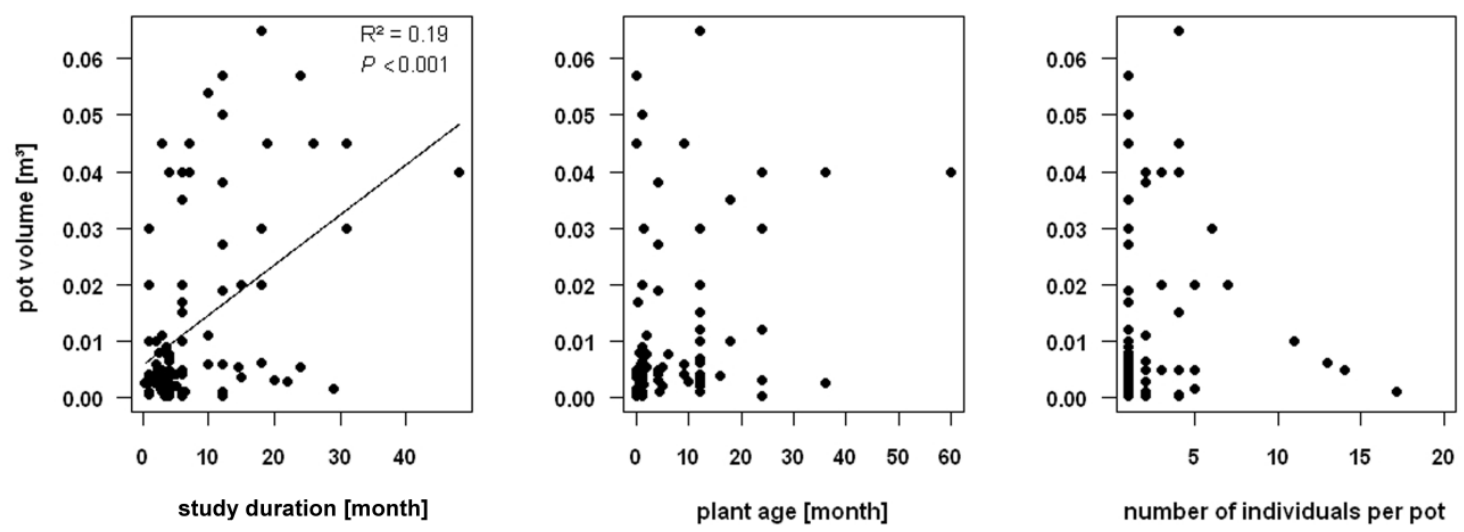

Fig. 3 Relationship between pot volume and study duration, plants age, and number of individuals per pot, respectively. Outliers were removed from data analysis.

There is neither a clear correlation between pot size and study duration in experiments with one single tree seedling, i.e. experiments with small pots did not last shorter than experiments with large pots. For small pot sizes $\left(\leq 0.001 \mathrm{~m}^{3}\right)$, we found that either a lot of young, i.e. small tree 
seedlings or a few older, i.e. larger individuals were used (Table 1). However, this was not true for medium sized $\left(\leq 0.01 \mathrm{~m}^{3}\right)$ and large pots $\left(\leq 0.1 \mathrm{~m}^{3}\right)$. Furthermore, there was no comprehensible correlation between study duration and plant age. In the same pot volumes, older tree seedlings were investigated for the same or even longer study duration than small individuals. Therefore, we could not further determine the reasons for choosing a specific pot volume.

Tab. 1 Mean age, mean number of plants per pot, and mean study duration divided in pot size and age classes ( $\mathrm{n}$ is the number of studies).

\begin{tabular}{|c|c|c|c|c|c|}
\hline pot size $\left[\mathrm{m}^{3}\right]$ & $\begin{array}{l}\text { age class } \\
\text { [months] }\end{array}$ & $\begin{array}{l}\text { mean age } \\
{[\text { months] }}\end{array}$ & $\begin{array}{l}\text { mean number } \\
\text { of plants/pot }\end{array}$ & $\mid \begin{array}{l}\text { mean study } \\
\text { duration } \\
\text { [months] }\end{array}$ & n \\
\hline \multirow{4}{*}{$\leq 0.001 \mathrm{~m}^{3}$} & $\leq 1$ & 0.68 & 3.52 & 4.93 & 10 \\
\hline & $\leq 10$ & 4.50 & 1.00 & 5.25 & 2 \\
\hline & $\leq 100$ & 20.00 & 1.33 & 12.00 & 3 \\
\hline & mean & 8.39 & 1.95 & 7.39 & \\
\hline \multirow{4}{*}{$\leq 0.01 \mathrm{~m}^{3}$} & $\leq 1$ & 0.61 & 2.56 & 5.86 & 20 \\
\hline & $\leq 10$ & 5.42 & 1.08 & 8.10 & 13 \\
\hline & $\leq 100$ & 16.18 & 3.00 & 5.45 & 11 \\
\hline & mean & 7.41 & 2.21 & 6.47 & \\
\hline \multirow{4}{*}{$\leq 0.1 \mathrm{~m}^{3}$} & $\leq 1$ & 0.29 & 2.88 & 15.75 & 8 \\
\hline & $\leq 10$ & 4.08 & 1.33 & 12.17 & 6 \\
\hline & $\leq 100$ & 24.00 & 3.11 & 15.63 & 10 \\
\hline & mean & 9.46 & 2.44 & 14.51 & \\
\hline
\end{tabular}

\section{Objectives}

The most frequently discussed subjects of the reviewed studies were plant ecology $(57.0 \%)$ and plant physiology (22.6\%). The remaining $20.4 \%$ dealt with genetics or other issues. In many pot experiments, a combination of two or more subjects was investigated, such as the growth response to flooding/drought and light/shade or the effect of genetic variation and drought on plant growth. The preference of studying plant growth or other physiological traits under varying environments can be explained by the well controllable conditions in pot experiments. Under natural conditions, plant response to a certain environmental factor, e.g. light, is often influenced by other factors, e.g. water availability. In pot experiments, these can be examined separately.

We assigned all studies to 14 different subject areas to analyze the methodical approaches of the pot experiments in more detail (Fig. 4). On the one hand, long term experiments on species diversity, composition, and density or biomass allocation studied the oldest tree seedlings in the largest pot volumes for the longest study duration. On the other hand, short term plant reactions such as tolerance to herbicides or isotopic differences between soil water and stem water studied young plants in small pots for only a few days or weeks (subject area 14). For other studies, we did not find clear correlations between subject and rooting volume or other pot characteristics. 
For example, although studies on competition (subject area 8) always have to comprise at least two competing individuals per pot, the mean pot volume was not significantly bigger than in those studies that investigated only one individual per pot.
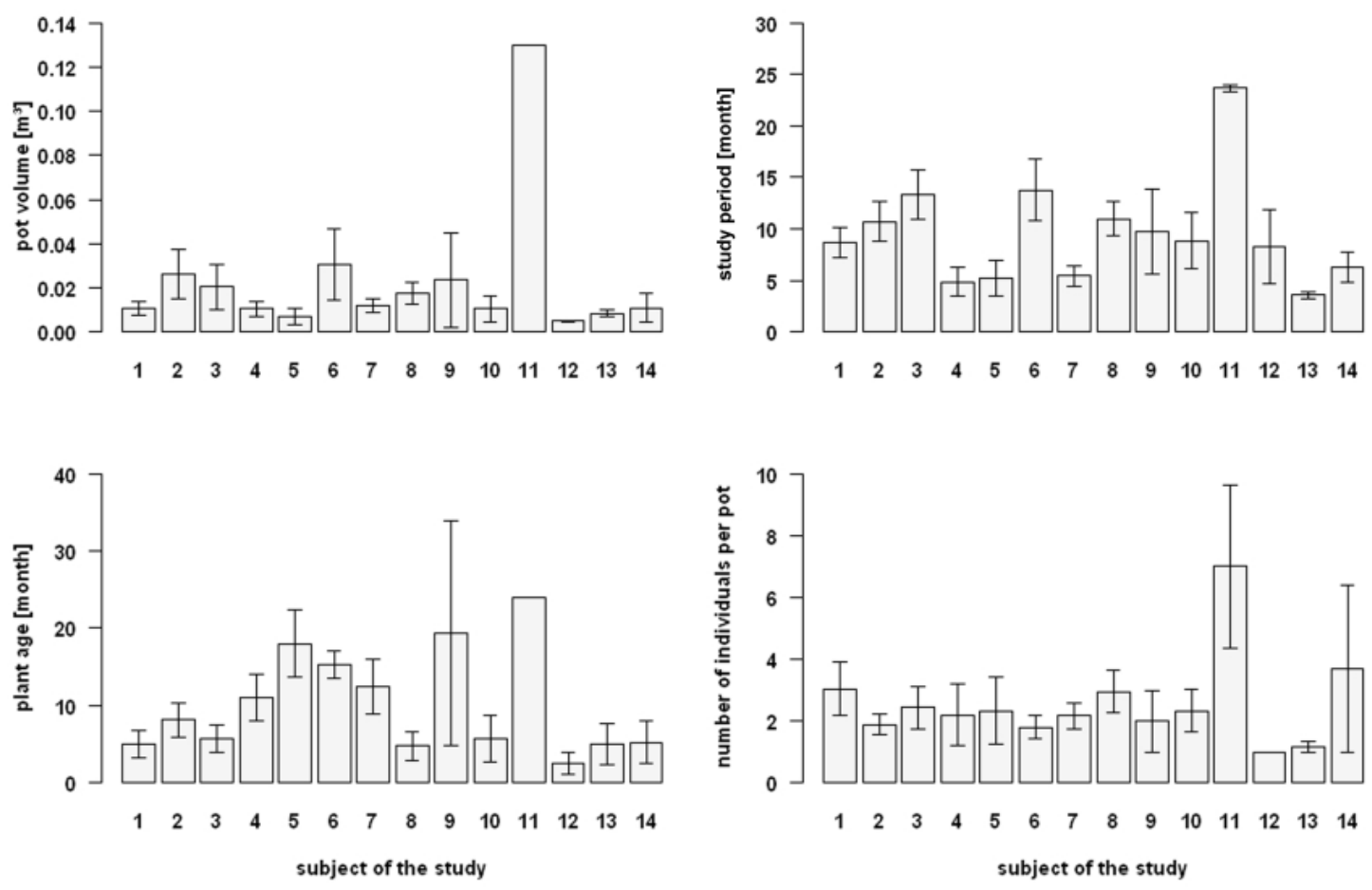

\begin{tabular}{|lllll|}
\hline 1 & growth response to nutrients an d other soil factors & 8 & competition \\
2 & growth response to soil water content & 9 & genetics \\
3 & growth respon se to light inten sity & 10 & mycorrhiza \\
4 & physiological respon se to water content & 11 & species diversity, composition, and den sity \\
5 & physiological respon se to light intensity & 12 & growth response to litter \\
6 & biomass allocation & 13 & herbivory, effect of earthworms \\
7 & effect of $\mathrm{O}_{3}, \mathrm{CO}_{2}$ & 14 & others \\
\hline
\end{tabular}

Fig. 4 Mean values \pm standard error of pot volume, study duration, plant age, and the number of individuals per pot for the different designated subject areas of the reviewed literature (93 studies). Outliers were removed from data analysis. Bars without \pm standard error were represented by only one study.

It seems as if other factors apart from creating the best possible growing conditions influenced the experimental design of many studies. The available budget often may be a limiting factor determining pot size, extent and duration of an experiment. This might be the reason why $36.6 \%$ of the experiments used recently germinated seedlings aged less than one month, which have the lowest space demands. However, here again, no study stated reasons for choosing their methodology. 


\section{Effect of transplanting}

Many studies seemed to use very young trees for the pot experiment for practical reasons. Accordingly, in the majority of the reviewed studies self-cultivated plants from seeds or cuttings $(70.2 \%)$ were used. This is the cheapest option for receiving plant material for an experiment. Additionally, self-cultivated seedlings are well adapted to the experimental growing conditions resulting in high survival rates. In contrast, older individuals obtained from nurseries $(14.9 \%)$ or excavated from natural stands $(4.3 \%)$ have to adapt to the new environment at first leading to an increased mortality rate. Unfortunately, almost none of the studies gave information on general mortality rate during the experiment unless investigating mortality e.g. due to drought treatment was an objective of the study. Only two studies (Rogers and Siemann 2003; Tanner et al. 2005), which used self germinated tree seedlings, reported very low mortality rates. Furthermore, seedlings that have naturally regenerated in the forest often have the disadvantage to vary in size and age in contrast to self-cultivated plants from seeds or nursery grown plants. This heterogeneity leads to results, which may mask the effect of the abiotic experimental factors, e.g., on biomass partitioning. Regardless of using self-cultivated seedlings or those obtained from nurseries, it has to be considered that plant physiology could be influenced by transplanting effects in the following vegetation period. In a pot experiment using 1-year-old nursery grown plants (Kawaletz et al. 2013), the effect of transplanting was found to have a strong impact on plant phenology, i.e. leaf flushing occurred later than in the second growing season.

\section{Study duration}

The study duration of the pot experiments varied from 0.2 months (Takahashi 1998) to 48 months (Wölfle et al. 2000). The average duration was 9.1 months and approximately half of the studies were conducted in less than half a year. This time included one vegetation season, where differences in plant growth as a response to varying environmental factors were studied. For studies dealing with the responses to different light and water regimes (subject areas 4 and 5 in Fig. 4) and elevated $\mathrm{O}_{3}$ or $\mathrm{CO}_{2}$ concentrations (subject area 7) fast changes of plant physiology (e.g., photosynthesis, transpiration rate) are measured. Thus, these subject areas were characterized by relatively short study durations.

In pot experiments lasting for more than one year, plants have more time to interact and season specific effects are reduced (Wilson 1988). Particularly in studies on woody species, the study duration is an important factor, due to their longevity and lower growth performance in contrast to most herbaceous plants. Study duration is dependent on the objective of the experiment. Studying long-term growth reactions needs more time (more than one vegetation period) than rather short-term responses of plant physiology (e.g., photosynthesis) to environmental changes. 


\section{Indoor vs. outdoor pot experiments}

Pot experiments can be conducted outdoors as well as indoors in greenhouses or climate chambers. In most of the reviewed literature, the studies were conducted indoors: either in greenor glasshouses $(40.9 \%)$ or in climate (growth) chambers $(11.8 \%)$. A total of $28.0 \%$ of the pot experiments took place outdoors, e.g., in experimental gardens, open fields, or nurseries. Other studies used semi open green- or shade houses $(10.8 \%)$ or a combination of indoor and outdoor locations $(4.3 \%)$. Again, $4.3 \%$ of the studies did not provide further information on the experimental site.

Apart from lower financial efforts, plants in outdoor pot experiments can grow under nearnatural conditions. The conditions are relatively comparable to natural habitats and the results of these outdoor pot experiments are better transferable to field grown plants. In contrast to in-situ studies, other variable factors such as soil composition, soil moisture, nutrient content, and plant characteristics can be standardized. Nevertheless, heterogeneity in temperature, light availability, and damages due to herbivores cannot be avoided and needs to be considered in the experimental design. Another option is the use of greenhouses and climate chambers, which create (full) controlled environments that are similar for all individuals and thus lead to a good reproducibility. However, it can be assumed that even in closed growth chambers it is hardly possible to fully control all environmental conditions affecting plant growth. In fact, the microclimate in greenhouses and to some extent even in climate chambers often is much more heterogeneous than under outdoor conditions. Light availability, for instance, may be different for each plant depending on the distance from the next lamp or wall of the growth chamber (Poorter et al. 2012b). Similar to outdoor pot experiments, these sources of errors have to be minimized and kept in mind when interpreting the results of indoors studies.

\section{Conclusions for future pot experiments with woody plants}

Field studies take place under natural conditions and are therefore often less expensive than pot experiments (no need of pots, soil, etc.). However, the success of in-situ experiments depends on the prevailing environmental conditions such as precipitation, deposition, and variation in soil and light conditions. If these factors are not exactly quantified, field experiments may provide doubtful and ambiguous results (Weber 1998). For example, during dry periods, soil water content can vary substantially compared to the constantly moist soil in pot experiments due to a frequent watering (Hata et al. 2010). Thus, various soil characteristics such as soil temperature, water, and nutrient availability differ between pot and field conditions (Townend and Dickinson 1995). The most important advantage of pot experiments is the simplification of environmental 
heterogeneity (Passioura 2006). In artificial but controlled environments, it is possible to study plant interactions more precisely (Weber 1998; Fetene 2003; Tanner et al. 2005; Bloor et al. 2008). Furthermore, pot experiments can be repeated as often as required under unchanging conditions (Gibson et al. 1999; Bloor et al. 2008). The influence of distracting factors such as differences in soil quality, precipitation, or herbivory can be either excluded or held constant (Gibson et al. 1999; Freckleton and Watkinson 2000). Due to the controlled environmental conditions, the results from a pot experiment are easier to interpret in comparison with field studies (Passioura 2006).

\section{Importance of pot size}

A crucial aspect of pot experiments is that plant performance depends on pot size and shape (see Endean and Carlson (1975) cited in Sutherland and Day (1988) and Poorter et al. (2012a)). The pot volume should be adequate in size to provide enough rooting space and nutrients for the plants over the whole study duration. Literature indicated that a limited pot size has various consequences on morphology, growth, and physiology of plants (e.g., Arp 1991, McConnaughay and Bazzaz 1991, McConnaughay et al. 1993; Ray and Sinclair 1998). One reason for the negative effect of small pots on overall plant growth is the restricted water availability due to the faster dehydration (Ray and Sinclair 1998). In the reviewed studies, a wide range of different pot sizes was used. Unfortunately, none of the studies gave explicit information whether the chosen pot volume provided enough rooting space for the whole experimental period, e.g. by informing about mortality rates caused by the experimental set-up. Aerts et al. (1991) proposed to choose a pot volume that covers the rooting volume under field conditions or at least a large part of it, i.e. they used a pot volume covering $90 \%$ of the rooting volume occupied in-situ. For comparing pot experiments with field studies, Arp (1991) assigned an estimated pot volume of $0.2 \mathrm{~m}^{3}$ for field grown plants. According to Poorter et al. (2012a), who recommended a ratio of less than $2.0 \mathrm{~g}$ dry biomass per liter pot volume, about $30 \%$ of the reviewed studies used a sufficient pot size.

Apart from pot size also the pot color could affect plant performance. Black pots, no matter whether the experiment takes place outdoors or indoors, often lead to elevated soil temperatures and soil water conditions (Poorter et al. 2012b). Soil temperature affects various physiological processes of trees such as stomatal conductance, nutrient absorption, and thus growth (Peng and Dang 2003). The so caused modifications of soil functions in black pots can be avoided by using light-colored pots or by covering dark-colored pots in reflective foil etc. However, there is evidence that plant growth and different physiological processes vary in their optimal soil temperatures (Dang and Cheng 2004). Accordingly, elevated soil temperature does not 
necessarily result in negative effects on plant growth by causing root damage (Newman and Davies 1988), but also can lead to an increased nutrient uptake until reaching a certain threshold (Adam et al. 2003). Soil temperature is highly connected with soil moisture content, which strongly influences plant performance. Therefore, special attention should be paid to regularly control the water status in the pots and prevent drought stress by frequent watering.

\section{Transferability}

Pot experiments create controlled but artificial conditions. Thus, plants have to acclimatize to the new environment after transplanting. To minimize this impact, several studies include an adjustment period before starting the experiment (Amundson et al. 1995; Gravatt and Kirby 1998; Meier 2007; Mielke and Schaffer 2010) to ensure equal starting conditions for all individuals. Nevertheless, a certain mortality rate has to be taken into account before the experiments start since some individuals often die during the adjustment period. In a recent pot experiment of Kawaletz et al. (2013), $23.1 \%$ of the plants died soon after planting due to transplanting effects. Dead seedlings should be replaced immediately to avoid differences between seedlings growth reaction to treatments. Willoughby et al. (2007) considered the anticipated germination rate based on seed viability by adjusting the seed numbers for the different species sown per pot.

To mimic the natural situation as closely as possible, some studies used soil substrates from the plant's origin (Amundson et al. 1995; Haase 2009; Zeugin 2010; Kohout et al. 2011) or from comparable stands (Wagner and Dreyer 1997; Tanner et al. 2005; Toledo-Aceves and Swaine 2007; Železnik et al. 2007; Schall et al. 2012). Most studies used standard potting soil or a variety of other substrates consisting of pure peat (Armas and Pugnaire 2011), humus (Dehlin et al. 2004), nutrient-poor sand (Löf and Welander 2000; Weih and Nordh 2005; Coq et al. 2012), or mixtures (Colin-Belgrand et al. 1991; McConnaughay et al. 1996; Ammer 2003; Parelle et al. 2006; Aranda et al. 2007). Independent of using natural or commercial soil, physical soil characteristics such as layering, pore space, drainage, and aeration are changed by mixing and sieving (Beadle 1962). Therefore, extrapolating from such data to natural conditions should be done with caution.

Another important aspect that has to be taken into account in pot experiments is the positive influence of mycorrhiza on plant performance (Blair and Perfecto 2004). Accordingly, negative plant performance could be due to the missing mycorrhizal symbiosis after transplantation to artificial growing conditions (Coq et al. 2012). In contrast to commercial standard potting soil, natural soils usually contain myccorhiza. Apart from the studies that clearly dealt with the effect of mycorrhiza in the experiment (Michelsen and Rosendahl 1990, Young et al. 1990, Baum et al. 
2002, Huat et al. 2002, Dehlin et al. 2004, Sell et al. 2005, Sanon et al. 2006, Zeleznik et al. 2007, Kohout et al. 2011), only a few studies inoculated pot soil with mycorrhizal funghi, e.g. by adding top-soil from the natural site to the potted seedlings (Lippert et al. 1996, Gunatilleke et al. 1997, Cornelissen et al. 1999, Saxe and Kerstiens 2005, Schall et al. 2012). The majority of the reviewed studies did not consider the impact of absent mycorrhiza on plant performance. However, the symbiosis with myccorhiza could increase the nutrient absorbing capacity of tree species and, thus, results of myccorhiza-free pot experiments are hardly transferable to field conditions.

In pot experiments early stages of tree seedlings are studied and transferring the results to adult trees is strongly limited (Weber 1998; Weih and Nordh 2005). Thus ontogenetic shifts in growth pattern, which play an important role, are not represented by e.g. short term pot experiments with small sized and young plants (Donovan and Ehleringer 1991). Thus, the impact of experimental factors on plant performance should not be analyzed independently from plant size and/or tree age.

Apparently, pot experiments are always restricted in their ability to imitate natural field conditions. Thus, transferring the results of pot experiments to natural conditions is a challenge and a lot of different factors have to be taken into account.

\section{Combination of pot and field studies}

Both pot experiments and in-situ studies have advantages as well as disadvantages. Field studies, on the one hand, occur under natural and more realistic conditions without as many limitations as in pot experiments, but with uncontrollable and varying influences that better should be eliminated. On the other hand, pot experiments under well controlled but artificial conditions allow the analysis of defined questions excluding or homogenizing certain environmental factors. However, for transferring the results of pot experiments to natural conditions could lead to several uncertainties. By linking experimental pot studies with in-situ studies the transferability of the results gained by pot experiments could be improved (Weber 1998; Freckleton and Watkinson 2000; Baum et al. 2002; Haase 2009). A good possibility could be to draw up several hypotheses which can be tested in pot or greenhouse experiments as well as under field conditions, i.e. the same or comparable measurements have to be applied to both pot experiment and field study (Freckleton and Watkinson 2000).

The implementation of additional in-situ measurements would at least double the amount of work, thus, most studies select only one of the two options. Merely $15.2 \%$ of the reviewed studies conducted supplemental in-situ experiments to compare the results to those of the pot experiments (Sanginga et al. 1991; Curtis and Teeri 1992; Long and Jones 1996; Bellingham et al. 2001; Baum et al. 2002; Rogers and Siemann 2003; Baraloto et al. 2005; Weih and Nordh 2005; 
Meier 2007; Schumacher 2007; Jung 2008; Haase 2009; Hata et al. 2010; Mangan et al. 2010; Zeugin 2010). Most of these studies combining field and pot experiments dealt with ecological objectives such as growth responses to different soil factors, i.e. subjects that are well suitable to be measured in pot experiments as well as in-situ. Unfortunately, even those studies that combined pot and field experiments often did not discuss the validity and transferability of both methods. Half of the studies using additional in-situ measurements clearly indicated a good transferability of the results gained from pot experiments to field conditions (Curtis and Teeri 1992; Long and Jones 1996; Baum et al. 2002; Rogers and Siemann 2003; Baraloto et al. 2006; Schumacher 2007; Mangan et al. 2010). Other studies assumed difficulties in transferring the observation of pot experiments to field conditions and adult trees (Mousseau and Saugier 1992; McConnaughay et al. 1993; Cahill 1999; Weber-Blaschke et al. 2002; Meier 2007). Sanginga et al. (1991) stated that pot experiments do not have sufficient predictive capacity to transfer the results to field conditions. The interaction of various biotic and abiotic factors that could be found in natural ecosystems may be excluded under the controlled conditions of pot experiments (Florentine and Fox 2003). In combined field and pot experiments, Weih and Nordh (2005) found some parameters (e.g., total leaf area, nitrogen) to be suitable for predicting the growth performance of field grown plants, whereas other parameters were less adequate (e.g., shoot biomass production, specific leaf area). According to Haase (2009), pot experiments and in-situ studies should be complementarily designed: under field conditions it is possible to conduct longterm investigations, whereas pot experiments allow direct measurements and a more practicable harvest of belowground plant tissue.

The literature review showed that the transferability of experimental results to natural conditions is depending on the individual study and has to be proven carefully. It seems to be helpful to combine pot experiments with in-situ field measurements wherever possible to enhance the informative value.

\section{Final remarks}

The literature review clearly revealed that most studies do not give exact information on their experimental set-up. Apparently, this information has rather lower priority compared to the findings of the study. However, the lack of clear information made it difficult to analyze the studies regarding methodology. We aimed to derive information on the quality of the pot experiment by means of this data. A second approach was to analyze whether the studies could approve their proposed hypotheses, since this could be another evidence for the quality of a pot 
experiment. Interestingly, $63.4 \%$ of the reviewed studies did not propose clear hypotheses. Thus, pot experiments seemed not to be used to prove explicit hypotheses, but rather to provide a general overview of a certain subject such as studying plant response to a great variety of abiotic and biotic factors. One reason for not drawing clear hypotheses could be unexpected results or problematic implementation of the experiment. In this case, the original intention of the study is hardy comprehensible. In case of clear hypotheses, approximately $17.2 \%$ of the studies could verify all and $13.1 \%$ some of their proposed hypotheses, whereas $6.1 \%$ of the studies found contrary results. In general, explicit hypotheses were expressed more often in studies published since the year $2000(52.3 \%)$ than in older studies $(14.3 \%)$. Studies with clearly formed hypotheses used older tree seedlings (mean age of 10.4 months in contrast to 8.3 months in studies without hypotheses) and longer study duration (12.0 months averaged in contrast to 6.6 months in studies without hypotheses. Eleven (31.4\%) of the pot studies that tested explicit hypotheses conducted additional in-situ measurements, whereas just four $(6.3 \%)$ of the studies without hypothesis did so. Possibly, the experience gained from previous pot experiments, i.e. studying tree seedlings over a longer period or implementing additional in-situ studies, enhance the probability of significant results.

In general, a pot experiment that did not show the requested results should not be disadvantageous for the scientists. In any case, sufficient information on the quality of the methodology should be given. This benefit of transparency could be helpful for future experimental designs as well as for meta-analyses.

\section{Supplementary material}

The following supplementary material is available at Forestry online:

Table S1 Summary of 93 studies describing pot experiments with tree species sorted by the year of publication ( $\mathrm{n} / \mathrm{a}=$ not applicable, this information is missing in the literature).

Supplementary references of Table S1

\section{Acknowledgements}

We would like to thank the Marianne and Dr. Fritz-Walter Fischer Foundation within the Stifterverband für die Deutsche Wissenschaft for funding our research. 


\section{References}

Adam, M.L., Michael Kelly, J., Graves, W.R. and Dixon, P.M. 2003 Net nitrate uptake by red maple is a function of root-zone temperature. J Plant Nutr 26: 203-222.

Aerts, R., Boot, R. and van der Aart, P. 1991 The relation between above- and belowground biomass allocation patterns and competitive ability. Oecologia 87: 551-559.

Ammer, C. 2003 Growth and biomass partitioning of Fagus sylvatica L. and Quercus robur L. seedlings in response to shading and small changes in the R/FR-ratio of radiation. Ann. For. Sci. 60: 163-171.

Amundson, R., Kohut, R. and Laurence, J. 1995 Influence of foliar N on foliar soluble sugars and starchs of red spruce saplings exposed to ambient and elevated ozone. Tree Physiol. 15: 167174.

Aranda, I., Pardos, M., Puértolas, J., Jiménez, M.D. and Pardos, J.A. 2007 Water-use efficiency in cork oak (Quercus suber) is modified by the interaction of water and light availabilities. Tree Physiol. 27: 671-677.

Armas, C. and Pugnaire, F.I. 2011 Plant neighbour identity matters to belowground interactions under controlled conditions. PLoS One 6: 1-7.

Arp, W.J. 1991 Effects of source-sink relations on photosynthetic acclimation to elevated $\mathrm{CO}_{2}$. Plant Cell Environ. 14: 869-875.

Baraloto, C., Bonal, D. and Goldberg, D.E. 2006 Differential seedling growth response to soil resource availability among nine neotropical tree species. J. Trop. Ecol. 22: 487-497.

Baraloto, C., Goldberg, D.E. and Bonal, D. 2005 Performance trade-offs among tropical tree seedlings in contrasting microhabitats. Ecology 86: 2461-2472.

Baum, C., Stetter, U. and Makeschin, F. 2002 Growth response of Populus trichocarpa to inoculation by the ectomycorrhizal fungus Laccaria laccata in a pot and a field experiment. For. Ecol. Manag. 163: 1-8.

Beadle, N. 1962 Soil phosphate and the delimitation on plant communities in Eastern Australia II. Ecology 43: 281-288.

Bellingham, P., Walker, L. and Wardle, D. 2001 Differential facilitation by a nitrogen-fixing shrub during primary succession influences relative performance of canopy tree species. J. Ecol. 89: $861-875$. 
Blair, B. 2001 Effect of soil nutrient heterogeneity on the symmetry of belowground competition. Plant Ecol. 156: 199-203.

Blair, B. and Perfecto, I. 2004 Successional status and root foraging for phosphorus in seven tropical tree species. Can. J. For. Res. 34: 1128-1135.

Bloor, J., Leadley, P. and Barthes, L. 2008 Responses of Fraxinus excelsior seedlings to grassinduced above- and below-ground competition. Plant Ecol. 194: 293-304.

Cahill, J.F. 1999 Fertilization effects on interactions between above- and belowground competition in an old field. Ecology 80: 466-480.

Colin-Belgrand, M., Dreyer, E. and Biron, P. 1991 Sensitivity of seedlings from different oak species to waterlogging: effects on root growth and mineral nutrition. Ann. Sci. For. 48: 193-204.

Coq, S., Weigel, J., Bonal, D. and Haettenschwiler, S. 2012 Litter mixture effects on tropical tree seedling growth - a greenhouse experiment. Plant Biol. 14: 630-640.

Cornelissen, J., Carnelli, A. and Callaghan, T. 1999 Generalities in the growth, allocation and leaf quality responses to elevated $\mathrm{CO}_{2}$ in eight woody species. New Phytol. 141: 401-409.

Curtis, P.S. and Teeri, J.A. 1992 Seasonal responses of leaf gas exchange to elevated carbon dioxide in Populus grandidentata. Can. J. For. Res. 22: 1320-1325.

Dang, Q.L. and Cheng, S. 2004 Effects of soil temperature on ecophysiological traits in seedlings of four boreal tree species. For Ecol Man 194 (1): 379-387.

Dehlin, H., Nilsson, M.-C., Wardle, D.A. and Shevtsova, A. 2004 Effects of shading and humus fertility on growth, competition, and ectomycorrhizal colonization of boreal forest tree seedlings. Can. J. For. Res. 34: 2573-2586.

Donovan, L.A. and Ehleringer, J. R. 1991 Ecophysiological differences among juvenile and reproductive plants of several woody species. Oecologia 86: 594-597.

Endean, F. and Carlson, L.W. 1975 The effect of rooting volume on the early growth of lodgepole pine seedlings. Can. J. For. Res. 5: 55-60.

Fetene, M. 2003 Intra- and inter-specific competition between seedlings of Acacia etbaica and a perennial grass (Hyparrenia hirta). J. Arid Environ. 55: 441-451.

Florentine, S.K. and Fox, J.E. 2003 Competition between Eucalyptus victrix seedlings and grass species. Ecol. Res. 18: 25-39. 
Freckleton, R.P. and Watkinson, A.R. 2000 Designs for greenhouse studies of interactions between plants: an analytical perspective. J. Ecol. 88: 386-391.

Gibson, D.J., Connolly, J., Hartnett, D.C. and Weidenhamer, J.D. 1999 Designs for greenhouse studies of interactions between plants. J. Ecol. 87: 1-16.

Gravatt, D.A. and Kirby, C.J. 1998 Patterns of photosynthesis and starch allocation in seedlings of four bottomland hardwood tree species subjected to flooding. Tree Physiol. 18: 411-417.

Groves, R. and Williams, J. 1975 Growth of skeleton weed (Chondrilla juncea L.) as affected by growth of subterranean clover (Trifolium subterraneum L.) and infection by Puccinea chondrillina Bubak and Syd. Aust. J. Agric. Res. 26: 975-983.

Gunatilleke, C.V.S., Gunatilleke, I.A.U.N., Perera, G.A.D., Burslem, D.F.R.P., Ashton, P.M.S. and Ashton, P.S. 1997 Responses to nutrient addition among seedlings of eight closely related species of Shorea in Sri Lanka. J. Ecol. 85: 301-311.

Haase, J.U. 2009 Biodiversity and ecosystem functioning: The effects of tree and litter diversity. Dissertation, University of Zurich.

Hata, K., Kato, H. and Kachi, N. 2010 Litter of an alien tree, Casuarina equisetifolia, inhibits seed germination and initial growth of a native tree on the Ogasawara Islands (subtropical oceanic islands). J. For. Res. 15: 384-390.

van Hees, A. 1997 Growth and morphology of pedunculate oak (Quercus robur L) and beech (Fagus sylvatica L) seedlings in relation to shading and drought. Ann. Sci. For. 54: 9-18.

Heilmeier, H., Baronius, K., Kuhn, A.J., Opfermann, M. and Nebe, W. 2000a Wachstum und Ernährung von Eberesche, Buche und Fichte im Gefäßversuch mit immissionsbelasteten Bodensubstraten aus dem Erzgebirge. J. Plant. Nutr. Soil Sci. 163: 57-63.

Heilmeier, H., Baronius, K., Nebe, W. and Kuhn, A.J. 2000b Wachstum und Ernährung von Birke, Buche, Fichte und Tanne bei unterschiedlichem Stickstoff- und Schwefelangebot im Gefäßversuch. Forstw. Cbl. 119: 161-176.

Huat, O.K., Awang, K., Hashim, A. and Majid, N.M. 2002 Effects of fertilizers and vesiculararbuscular mycorrhizas on the growth and photosynthesis of Azadirachta excelsa (Jack) Jacobs seedlings. For. Ecol. Manag. 158: 51-58.

Jung, P. 2008 Effect of faeces from different lepidopterans, after feeding on pines, on growth in hight and root collar diameter of young pines, birches, and oaks. Allg. Forst Jagdztg. 179: 7-13. 
Kawaletz H., Mölder I., Zerbe S., Annighöfer P., Terwei A., Ammer C. 2013 Exotic tree seedlings are much more competitive than natives but show underyielding when growing together. J Plant Ecol 6 (4): 305-315.

Kohout, P., Sykorova, Z., Bahram, M., Hadincová, V., Albrechtová, J., Tedersoo, L. and Vohník, M. 2011 Ericaceous dwarf shrubs affect ectomycorrhizal fungal community of the invasive Pinus strobus and native Pinus sylvestris in a pot experiment. Mycorrbiza 21: 403-412.

Kramer, P. 1936 Effect of variation in length of day on growth and dormancy of trees. Plant Physiol. 11: 127-137.

Lippert, M., Häberle, K.-H., Steiner, K., Payer, H.-D. and Rehfuess, K.-E. 1996 Interactive effects of elevated $\mathrm{CO}_{2}$ and $\mathrm{O}_{3}$ on photosynthesis and biomass production of clonal 5-yearold Norway spruce [Picea abies (L.) Karst.] under different nitrogen nutrition and irrigation treatments. Trees 10: 382-392.

Löf, M. and Welander, N.T. 2000 Carry-over effects on growth and transpiration in Fagus sylvatica seedlings after drought at various stages of development. Can. J. For. Res. 30: 468-475.

Long, T.J. and Jones, R.H. 1996 Seedling growth strategies and seed size effects in fourteen oak species native to different soil moisture habitats. Trees 11:1-8.

Mangan, S.A., Schnitzer, S.A., Herre, E.A., Mack, K.M.L., Valencia, M.C., Sanchez, E.I. and Bever, J.D. 2010 Negative plant-soil feedback predicts tree-species relative abundance in a tropical forest. Nature 466: 752-755.

McConnaughay, K.D.M. and Bazzaz, F.A. 1991 Is physical space a soil resource? Ecology 72: 94-103.

McConnaughay, K.D.M., Berntson, G.M. and Bazzaz, F.A. 1993 Limitations to $\mathrm{CO}_{2}$-induced growth enhancement in pot studies. Oecologia 94: 550-557.

McConnaughay, K.D.M., Nicotra, A.B. and Bazzaz, F.A. 1996 Rooting volume, nutrient availability, and $\mathrm{CO}_{2}$-induced growth enhancements in temperate forest tree seedlings. Ecol. Appl. 6: 619-627.

McPhee, C.S. and Aarssen, L.W. 2001 The separation of above- and below-ground competition in plants a review and critique of methodology. Plant Ecol. 152: 119-136.

Meier, I.C. 2007: Aboveground and belowground response of European beech to drought: field studies and experiments. Dissertation, University of Göttingen. 
Michelsen, A. and Rosendahl, S. 1990 The effect of VA mycorrhizal fungi, phosphorus and drought stress on the growth of Acacia nilotica and Leucaena leucocephala seedlings. Plant and Soil 124: 7-13.

Mielke, M.S. and Schaffer, B. 2010 Leaf gas exchange, chlorophyll fluorescence and pigment indexes of Eugenia uniflora L. in response to changes in light intensity and soil flooding. Tree Physiol. 30: 45-55.

van der Moezel, P.G., Pearce-Pinto, G.V.N. and Bell, D.T. 1991 Screening for salt and waterlogging tolerance in Eucalyptus and Melaleuca species. For. Ecol. Manag. 40: 27-37.

Mousseau, M. and Saugier, B. 1992 The direct effect of increased $\mathrm{CO}_{2}$ on gas exchange and growth of forest tree species. J. Exp. Bot. 43: 1121-1130.

Newman, S.E. and Davies Jr, F.T. 1988 Influence of field bed position, ground surface color, mycorrhizal fungi, and high root-zone temperature in woody plant container production. Plant Soil 112: 29-35.

Osunkoya, O.O., Othman, F.E. and Kahar, R.S. 2005 Growth and competition between seedlings of an invasive plantation tree, Acacia mangium, and those of a native Borneo heathforest species, Melastoma beccarianum. Ecol. Res. 20: 205-214.

Parelle, J., Brendel, O., Bodénès, C., Berveiller, D., Dizengremel, P., Jolivet, Y. and Dreyer, E. 2006 Differences in morphological and physiological responses to water-logging between two sympatric oak species (Quercus petraea [Matt.] Liebl., Quercus robur L.). Ann. For. Sci. 63: 849-859.

Passioura, J.B. 2006 The perils of pot experiments. Funct. Plant Biol. 33: 1075-1079.

Peng, Y.Y.and Dang, Q. L. 2003 Effects of soil temperature on biomass production and allocation in seedlings of four boreal tree species. For Ecol Man 180: 1-9.

Poorter, H., Bühler, J., van Dusschoten, D., Climent, J. and Postma, J.A. 2012a Pot size matters: a meta-analysis of the effects of rooting volume on plant growth. Funct. Plant Biol. 39: 839850.

Poorter, H., Fiorani, F., Stitt, M., Schurr, U., Finck, A., Gibon, Y., Usadel, B., Munns, R., Atkin, O.K., Tardieu, F. and Pons, T.L. 2012b The art of growing plants for experimental purposes: a practical guide for the plant biologist. Funct. Plant Biol. 39: 821-838.

Ray, J. and Sinclair, T. 1998 The effect of pot size on growth and transpiration of maize and soybean during water deficit stress. J. Exp. Bot. 49: 1381-1386. 
Rogers, W.E. and Siemann, E. 2003 Effects of simulated herbivory and resources on Chinese tallow tree (Sapium sebiferum, Euphorbiaceae) invasion of native coastal prairie. Am. J. Bot. 90: 243-249.

Sanginga, N., Gwaze, D. and Swift, M. 1991 Nutrient requirements of exotic tree species in Zimbabwe. Plant Soil 132: 197-205.

Sanon, A., Martin, P., Thioulouse, J., Plenchette, C., Spichiger, R., Lepage, M. and Duponnois, R. 2006 Displacement of an herbaceous plant species community by mycorrhizal and nonmycorrhizal Gmelina arborea, an exotic tree, grown in a microcosm experiment. Mycorrbiza 16: $125-132$.

Saxe, H. and Kerstiens, G. 2005 Climate change reverses the competitive balance of ash and beech seedlings under simulated forest conditions. Plant Biology 7: 375-386.

Schall, P., Lödige, C., Beck, M. and Ammer, C. 2012 Biomass allocation to roots and shoots is more sensitive to shade and drought in European beech than in Norway spruce seedlings. For. Ecol. Manag. 266: 246-253.

Schumacher, E.M. 2007 Variation in growth responses among and within native and invasive juvenile trees in Seychelles. Dissertation, ETH Zürich.

Sell, J., Kayser, A., Schulin, R. and Brunner, I. 2005 Contribution of ectomycorrhizal fungi to cadmium uptake of poplars and willows from a heavily polluted soil. Plant and Soil 277: 245-253.

Sutherland, D.C. and Day, R.J. 1988 Container volume affects survival and growth of white spruce, black spruce, and jack pine seedlings: a literature review. Northern J. Appl. Forestry 5: 185-189.

Takahashi, K. 1998 Oxygen isotope ratios between soil water and stem water of trees in pot experiments. Ecol. Res. 13: 1-5.

Tanner, E.V.J., Teo, V.K., Coomes, D.A. and Midgley, J.J. 2005 Pair-wise competition-trials amongst seedlings of ten dipterocarp species; the role of initial height, growth rate and leaf attributes. J. Trop. Ecol. 21: 317-328.

Toledo-Aceves, T. and Swaine, M.D. 2007 Above- and below-ground competition between the liana Acacia kamerunensis and tree seedlings in contrasting light environments. Plant Ecol. 196: $233-244$.

Townend, J. and Dickinson, A.L. 1995 A comparison of rooting environments in containers of different sizes. Plant and Soil 175: 139-146. 
Wagner, P. and Dreyer, E. 1997 Interactive effects of waterlogging and irradiance on the photosynthetic performance of seedlings from three oak species displaying different sensitivities (Quercus robur, Q. petraea and Q. rubra). Ann. Sci. For. 54: 409-429.

Weber, G. 1998 Wachstum und Ernährungszustand von jungen Eschen (Fraxinus excelsior L.) und Bergahornen (Acer pseudoplatanus L.) in Abhängigkeit von der Basen- und Al-Sättigung und vom Wasserhaushalt natürlicher Böden. Hieronymus, München.

Weber-Blaschke, G., Claus, M. and Rehfuess, K.E. 2002 Growth and nutrition of ash (Fraxinus excelsior L.) and sycamore (Acer pseudoplatanus L.) on soils of different base saturation in pot experiments. For. Ecol. Manag. 167: 43-56.

Weber-Blaschke, G. and Rehfuess, K.E. 2002 Correction of Al toxicity with European ash (Fraxinus excelsior L.) growing on acid soils by fertilization with $\mathrm{Ca}$ and $\mathrm{Mg}$ carbonate and sulfate in pot experiments. For. Ecol. Manag. 167: 173-183.

Weih, M. and Nordh, N. 2005 Determinants of biomass production in hybrid willows and prediction of field performance from pot studies. Tree Physiol. 25: 1197-1206.

White, V.A. and Holt, J.S. 2005 Competition of artichoke thistle (Cynara cardunculus) with native and exotic grassland species. Weed Science 53: 826-833.

Willoughby, I., Dixon, F.L., Clay, D.V. and Jinks, R.L. 2007 Tolerance of broadleaved tree and shrub seedlings to preemergence herbicides. New For. 34: 1-12.

Wilson, J.B. 1988 Shoot competition and root competition. J. Appl. Ecol. 25: 279-296.

Wölfle, C., Häberle, K.-H., Kölling, C. and Rehfuess, K.E. 2000 Über den Einfluß von wiederholter Ammoniumnitrat-Düngung auf Substrat, Ernährungszustand und Wachstum junger Fichten (Picea abies [L.] Karst.) in den Hochlagen des Bayerischen Waldes Ergebnisse eines Container-Experiments. Forstw. Cbl. 119: 114-127.

Young, C.-C. 1990 Effects of phosphorus-solubilizing bacteria and vesicular-arbuscular mycorrhizal fungi on the growth of tree species in subtropical-tropical soils. Soil Sc. Plant Nutr. 36: 225-231.

Železnik, P., Hrenko, M., Then, C., Koch, N., Grebenc, T., Levanič, T. and Kraigher, H. 2007 CASIROZ: Root parameters and types of ectomycorrhiza of young beech plants exposed to different ozone and light regimes. Plant Biol. 9: 298-308.

Zeugin, F. 2010 The functional significance of tree diversity for nutrient acquisition in a tropical tree plantation. Dissertation, ETH Zürich. 


\section{Appendix}

Table S1 Summary of 93 studies describing pot experiments with tree species sorted by the year of publication (n/a = not applicable, this information is missing in the literature).

\begin{tabular}{|c|c|c|c|c|c|c|c|c|c|}
\hline reference & species & objective & $\begin{array}{l}\text { age } \\
\text { [month] }\end{array}$ & $\begin{array}{ll}\text { pot } & \text { volume } \\
{\left[\mathrm{m}^{3}\right]} & \end{array}$ & $\begin{array}{l}\text { plants per } \\
\text { pot }\end{array}$ & 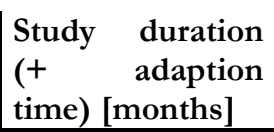 & location & plants origin & $\begin{array}{l}\text { additional } \\
\text { in-situ study }\end{array}$ \\
\hline Kramer (1936) & $\begin{array}{l}\text { Fagus grandifolia, } \\
\text { Fraxinus americana, } \\
\text { F.pennsylvanica var. } \\
\text { lanceolata, Liquidambar } \\
\text { styraciflua, Liriodendron } \\
\text { tulipifera, Pinus taeda, } \\
\text { Quercus alba, Q. borealis } \\
\text { maxima, Q. stellata, } \\
\text { Robinia pseudoacacia }\end{array}$ & $\begin{array}{l}\text { growth response to } \\
\text { light intensity }\end{array}$ & 0,12 , or 24 & $\begin{array}{l}\mathrm{n} / \mathrm{a} \\
(\mathrm{d}=15.24 \mathrm{~cm} \\
\text { or } 20.32 \mathrm{~cm})\end{array}$ & 1 & $\begin{array}{l}\text { approx. } 30, \\
3 \text { growing seasons }\end{array}$ & greenhouse & $\mathrm{n} / \mathrm{a}$ & no \\
\hline $\begin{array}{ll}\text { McComb } & \text { and } \\
\text { Kapel (1942) }\end{array}$ & $\begin{array}{lr}\text { Fraxinus } & \text { pennsylvanica } \\
\text { lanceolata, } & \text { Robinia } \\
\text { pseudoacacia } & \\
\end{array}$ & $\begin{array}{l}\text { growth response to } \\
\text { soil acidity and } \\
\text { fertility }\end{array}$ & 12 & $\begin{array}{l}0.015 \\
\text { (4 gallons) }\end{array}$ & 3 to 5 & 6 & greenhouse & $\begin{array}{l}\text { cultured from } \\
\text { seeds }\end{array}$ & no \\
\hline Moore (1959) & $\begin{array}{l}\text { Eucalyptus melliodora, } \\
\text { E. rossi }\end{array}$ & $\begin{array}{l}\text { growth response to } \\
\text { competition and soil } \\
\text { factors }\end{array}$ & 0 & $\begin{array}{l}\mathrm{n} / \mathrm{a} \\
(\mathrm{d}=15.24 \mathrm{~cm})\end{array}$ & 2 & 5.75 & $\mathrm{n} / \mathrm{a}$ & $\begin{array}{l}\text { cultured from } \\
\text { seeds }\end{array}$ & no \\
\hline Beadle (1962) & $\begin{array}{l}\text { Acacia suaveolens, } \\
\text { Eucalyptus gummifera, } \\
\text { E.pilularis, E. saligna, } \\
\text { Hakea dactyloides, } \\
\text { Leptospermum } \\
\text { persiciflorum }\end{array}$ & $\begin{array}{l}\text { growth response to } \\
\text { soil phosphate }\end{array}$ & $\mathrm{n} / \mathrm{a}$ & $\mathrm{n} / \mathrm{a}$ & 1 & 5 & greenhouse & $\begin{array}{l}\text { cultured from } \\
\text { seeds }\end{array}$ & no \\
\hline $\begin{array}{l}\text { Kress and Skelly } \\
(1982)\end{array}$ & $\begin{array}{l}\text { Acer saccharum, Fraxinus } \\
\text { americana, F. pennsyl- } \\
\text { vanica, Liquidambar } \\
\text { styraciflua, Liriodendron } \\
\text { tulipifera, Quercus phellos, } \\
\text { Pinus rigida, P. tadea, } \\
\begin{array}{l}\text { P. virginiana, Platanus } \\
\text { occidentalis }\end{array}\end{array}$ & $\begin{array}{l}\text { growth response to } \\
\text { ozone and } \mathrm{CO}_{2}\end{array}$ & 0.75 & 0.00045 & 4 & 1 & greenhouse & $\begin{array}{l}\text { cultured from } \\
\text { seeds }\end{array}$ & no \\
\hline
\end{tabular}




\section{Continuation of Table S1}

\begin{tabular}{|c|c|c|c|c|c|c|c|c|c|}
\hline reference & species & objective & $\begin{array}{l}\text { age } \\
\text { [month] }\end{array}$ & \begin{tabular}{|ll} 
pot & volume \\
{$\left[\mathrm{m}^{3}\right]$} &
\end{tabular} & $\begin{array}{l}\text { plants per } \\
\text { pot }\end{array}$ & $\begin{array}{|lr|}\text { Study } & \text { duration } \\
(+ & \text { adaption } \\
\text { time }) & \text { [months }] \\
\end{array}$ & location & plants origin & $\begin{array}{l}\text { additional } \\
\text { in-situ study }\end{array}$ \\
\hline $\begin{array}{l}\text { Oberbauer et al. } \\
(1985)\end{array}$ & $\begin{array}{l}\text { a) Ochroma lagopus, } \\
\text { b) Pentaclethra macroloba }\end{array}$ & $\begin{array}{l}\text { growth and physio- } \\
\text { logical response to } \\
\mathrm{CO}_{2} \text { enrichment }\end{array}$ & 0 & $\begin{array}{l}\mathrm{n} / \mathrm{a} \\
\text { (a) } \mathrm{d}=11 \mathrm{~cm}, \\
\text { b) } \mathrm{d}=18 \mathrm{~cm})\end{array}$ & $\mathrm{n} / \mathrm{a}$ & a) 2, b) 4 & $\begin{array}{l}\text { growth } \\
\text { chamber }\end{array}$ & $\begin{array}{l}\text { cultured from } \\
\text { seeds }\end{array}$ & no \\
\hline $\begin{array}{ll}\text { Bongarten } & \text { and } \\
\text { Teskey (1987) } & \\
\end{array}$ & Pinus tadea & \begin{tabular}{|l|} 
growth response to \\
soil water contents
\end{tabular} & 0 & 0.00064 & 1 & 12 & greenhouse & \begin{tabular}{|l|} 
cultured from \\
seeds
\end{tabular} & no \\
\hline Hollinger (1987) & $\begin{array}{|lr|}\text { Nothofagus } & \text { fusca, Pinus } \\
\text { radiate, } & \text { Pseudotsuga } \\
\text { menziesii } & \\
\end{array}$ & $\begin{array}{l}\text { physiological } \\
\text { response to elevated } \\
\mathrm{CO}_{2} \\
\end{array}$ & 9 & 0.004 & $\mathrm{n} / \mathrm{a}$ & 4 & $\begin{array}{l}\text { growth } \\
\text { chamber }\end{array}$ & nursery & no \\
\hline $\begin{array}{l}\text { Fetcher et al. } \\
(1988)\end{array}$ & $\begin{array}{l}\text { Liquidambar styraciflua, } \\
\text { Pinus taeda }\end{array}$ & $\begin{array}{l}\text { response of carbon } \\
\text { exchange rate to } \\
\text { elevated } \mathrm{CO}_{2}\end{array}$ & 0 & 0.0036 & $n / a$ & 15 & greenhouse & $\begin{array}{l}\text { cultured from } \\
\text { seeds }\end{array}$ & no \\
\hline $\begin{array}{l}\text { Gonzáles Cascón } \\
\text { et al. (1989) }\end{array}$ & Abies alba & \begin{tabular}{|l|}
$\begin{array}{l}\text { growth response to } \\
\text { base saturation }\end{array}$ \\
\end{tabular} & 12 & 0.0062 & 13 & 18 & outdoors & $\mathrm{n} / \mathrm{a}$ & no \\
\hline $\begin{array}{l}\text { Kaushal et al. } \\
(1989)\end{array}$ & $\begin{array}{l}\text { Cedrus atlantica, Pinus } \\
\text { nigra ssp. laricio var. } \\
\text { corsicana }\end{array}$ & $\begin{array}{l}\text { growth response to } \\
\mathrm{CO}_{2} \text { enrichment }\end{array}$ & 9 & $\begin{array}{l}0.00585 \\
\text { or } 0.006\end{array}$ & 1 & $10(+1)$ & greenhouse & $\begin{array}{l}\text { cultured from } \\
\text { seeds }\end{array}$ & no \\
\hline $\begin{array}{l}\text { Michelsen and } \\
\text { Rosendahl (1990) }\end{array}$ & $\begin{array}{l}\text { Acacia nilotica, Leucaena } \\
\text { leucocephala }\end{array}$ & $\begin{array}{l}\text { growth response to } \\
\text { drought, phos- } \\
\text { phorous availability, } \\
\text { mycorrhiza } \\
\end{array}$ & $\mathrm{n} / \mathrm{a}$ & 0.0012 & 1 & 3 & greenhouse & $\mathrm{n} / \mathrm{a}$ & no \\
\hline Young (1990) & $\begin{array}{lr}\text { Acaciar } & \text { confusa, } \\
\text { A. mangium, Lencaena } \\
\text { leucocephala, Liquidarnber } \\
\text { formosana }\end{array}$ & $\begin{array}{l}\text { growth response to } \\
\text { mycorrhiza and } \\
\text { bacteria }\end{array}$ & 0 & 0.00025 & 1 & 3.4 & greenhouse & $\begin{array}{l}\text { cultured from } \\
\text { seeds }\end{array}$ & no \\
\hline $\begin{array}{l}\text { Colin-Belgrand et } \\
\text { al. (1991) }\end{array}$ & $\begin{array}{l}\text { Quercus palustris, } \\
\text { Q. robur, Q. rubra }\end{array}$ & \begin{tabular}{|l|}
$\begin{array}{l}\text { growth response to } \\
\text { flooding }\end{array}$ \\
\end{tabular} & 4 & 0.005 & 1 & 2.2 & greenhouse & \begin{tabular}{|l|}
$\begin{array}{l}\text { cultured from } \\
\text { seeds }\end{array}$ \\
\end{tabular} & no \\
\hline $\begin{array}{l}\text { Sanginga et al. } \\
\text { (1991) }\end{array}$ & \begin{tabular}{|lr} 
Acaciar & bolosericea, \\
Casuarina & cunning- \\
hamiana, & Eucalyptus \\
camaldulensis, & E. grandis, \\
E. tereticornis, & \\
Leucaena leucocephala
\end{tabular} & $\begin{array}{l}\text { growth response to } \\
\text { nutrients }\end{array}$ & 0.5 & 0.005 & 4 & 3 & greenhouse & $\begin{array}{l}\text { cultured from } \\
\text { seeds }\end{array}$ & yes \\
\hline $\begin{array}{l}\text { van der Moezel et } \\
\text { al. (1991) }\end{array}$ & $\begin{array}{l}40 \text { Eucalyptus and } 20 \\
\text { Melaleuca species }\end{array}$ & $\left|\begin{array}{l}\text { growth response to } \\
\text { flooding and salinity }\end{array}\right|$ & 4 & $\begin{array}{l}\mathrm{n} / \mathrm{a} \\
(\mathrm{d}=25 \mathrm{~cm})\end{array}$ & 4 & 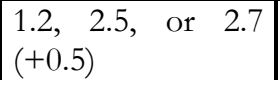 & greenhouse & $\begin{array}{l}\text { cultured from } \\
\text { seeds }\end{array}$ & no \\
\hline
\end{tabular}




\section{Continuation of Table S1}

\begin{tabular}{|c|c|c|c|c|c|c|c|c|c|}
\hline reference & species & objective & \begin{tabular}{|l} 
age \\
[month]
\end{tabular} & \begin{tabular}{|ll} 
pot & volume \\
{$\left[\mathrm{m}^{3}\right]$} &
\end{tabular} & $\begin{array}{l}\text { plants per } \\
\text { pot }\end{array}$ & \begin{tabular}{|ll} 
Study & duration \\
$(+$ & adaption \\
time $)$ & [months] \\
\end{tabular} & location & plants origin & $\begin{array}{l}\text { additional } \\
\text { in-situ study }\end{array}$ \\
\hline Bunce (1992) & $\begin{array}{l}\text { Acer rubrum, A. sac- } \\
\text { charinum, Quercus prinus, } \\
\text { Q. robur, Malus domestica }\end{array}$ & $\begin{array}{l}\text { physiological } \\
\text { response to elevated } \\
\mathrm{CO}_{2}\end{array}$ & $\mathrm{n} / \mathrm{a}$ & $\begin{array}{l}\mathrm{n} / \mathrm{a} \\
(\mathrm{d}=15 \mathrm{~cm})\end{array}$ & 1 & $\mathrm{n} / \mathrm{a}$ & outdoors & $\begin{array}{l}\text { cultured from } \\
\text { seeds }\end{array}$ & no \\
\hline $\begin{array}{l}\text { Curtis and Teeri } \\
(1992)\end{array}$ & Populus grandidentata & $\begin{array}{l}\text { growth and } \\
\text { physiological } \\
\text { response to elevated } \\
\mathrm{CO}_{2} \\
\end{array}$ & 1.5 & 0.0024 & 1 & 2.3 & $\begin{array}{l}\text { open-top } \\
\text { chamber }\end{array}$ & $\begin{array}{l}\text { cultured from } \\
\text { seeds }\end{array}$ & yes \\
\hline $\begin{array}{l}\text { Pashanasi et al. } \\
(1992)\end{array}$ & $\begin{array}{l}\text { Bactris gasipaes, Bixa } \\
\text { orellana, Eugenia stipitata }\end{array}$ & $\begin{array}{l}\text { growth response to } \\
\text { earthworm }\end{array}$ & 0 & $\begin{array}{l}\text { plastic bags } \\
(28 \times 19 \mathrm{~cm})\end{array}$ & $n / a$ & 2,3 , or 4 & \begin{tabular}{|l|}
$\begin{array}{l}\text { outdoors } \\
\text { under an } \\
\text { open shed }\end{array}$ \\
\end{tabular} & $\begin{array}{l}\text { cultured from } \\
\text { seeds }\end{array}$ & no \\
\hline $\begin{array}{l}\text { Silvola and } \\
\text { Ahlholm (1992) }\end{array}$ & Salix $x$ dasyclado & \begin{tabular}{|l|} 
physiological \\
response to $\mathrm{CO}_{2}$, \\
photosynthesis
\end{tabular} & $\mathrm{n} / \mathrm{a}$ & 0.0035 & 1 & 4 & greenhouse & $\begin{array}{l}\text { cultured from } \\
\text { cuttings }\end{array}$ & no \\
\hline Grulke et al. (1993) & Pinus ponderosa & $\begin{array}{l}\text { physiological } \\
\text { response to elevated } \\
\mathrm{CO}_{2} \\
\end{array}$ & $\mathrm{n} / \mathrm{a}$ & 0.0003 & 1 & 4 & $\begin{array}{l}\text { growth } \\
\text { chamber }\end{array}$ & $\begin{array}{l}\text { cultured from } \\
\text { seeds }\end{array}$ & no \\
\hline Vivin et al. (1993) & $\begin{array}{l}\text { Quercus petraea, Q. robur, } \\
\text { Q. rubra }\end{array}$ & $\begin{array}{l}\text { growth response to } \\
\text { drought }\end{array}$ & 24 & 1.62 & 40 & $\begin{array}{l}\mathrm{n} / \mathrm{a} \\
(+36)\end{array}$ & \begin{tabular}{|l|} 
outdoors and \\
semi-open \\
greenhouse \\
\end{tabular} & nursery & no \\
\hline Madsen (1994) & Fagus sylvatica & $\begin{array}{l}\text { growth response to } \\
\text { light intensity and } \\
\text { soil moisture }\end{array}$ & 1 & 0.02 & 7 & 15 & outdoors & $\begin{array}{l}\text { cultured from } \\
\text { seeds }\end{array}$ & no \\
\hline $\begin{array}{l}\text { Tognetti et al. } \\
(1994)\end{array}$ & Fagus sylvatica & $\begin{array}{|lr|}\text { physiological } & \text { and } \\
\text { morphological } & \\
\text { responses to light } \\
\text { intensity and soil } \\
\text { water content } & \end{array}$ & 36 & 0.0025 & 1 & $4(+5)$ & $\begin{array}{l}\text { growth } \\
\text { chamber }\end{array}$ & $\begin{array}{l}\text { cultured from } \\
\text { seeds }\end{array}$ & no \\
\hline $\begin{array}{l}\text { Amundson et al. } \\
(1995)\end{array}$ & Picea rubens & $\begin{array}{l}\text { effects of foliar } \\
\text { nitrogen and ex- } \\
\text { posure to ozone on } \\
\text { foliar carbohydrate } \\
\text { reserves }\end{array}$ & 240 & 0.36 & 1 & $4(+60)$ & outdoors & $\begin{array}{l}\text { excavated } \\
\text { from natural } \\
\text { stands }\end{array}$ & no \\
\hline
\end{tabular}




\section{Continuation of Table S1}

\begin{tabular}{|c|c|c|c|c|c|c|c|c|c|}
\hline reference & species & objective & $\begin{array}{l}\text { age } \\
\text { [month] }\end{array}$ & \begin{tabular}{|ll} 
pot & volume \\
{$\left[\mathrm{m}^{3}\right]$} &
\end{tabular} & $\begin{array}{l}\text { plants per } \\
\text { pot }\end{array}$ & \begin{tabular}{|ll} 
Study & duration \\
$(+$ & adaption \\
time $)$ & [months]
\end{tabular} & location & plants origin & $\begin{array}{l}\text { additional } \\
\text { in-situ study }\end{array}$ \\
\hline $\begin{array}{l}\text { Barnes et al. } \\
\text { (1995); Pfirrmann } \\
\text { et al. (1996) }\end{array}$ & Picea abies & \begin{tabular}{|l|} 
physiological res- \\
ponse to elevated \\
$\mathrm{CO}_{2}$
\end{tabular} & 60 & 0.04 & 3 & $6(+24)$ & greenhouse & $\mathrm{n} / \mathrm{a}$ & no \\
\hline $\begin{array}{l}\text { Lippert et } \quad \text { al. } \\
(1996)\end{array}$ & Picea abies & $\begin{array}{l}\text { growth and physio- } \\
\text { logical response to } \\
\text { ozone and elevated } \\
\mathrm{CO}_{2}\end{array}$ & 36 & 0.04 & 4 & $7(+22)$ & $\begin{array}{l}\text { growth } \\
\text { chambers }\end{array}$ & $\begin{array}{l}\text { cultured from } \\
\text { cuttings }\end{array}$ & no \\
\hline $\begin{array}{l}\text { Long and Jones } \\
(1996)\end{array}$ & $\begin{array}{l}14 \text { oak species: Quercus } \\
\text { falcate, Q. hemisphaerica, } \\
\text { Q. laevis, Q. laurifolia, } \\
\text { Q. lyrata, Q. margaretta, } \\
\text { Q. marilandica, Q. nigra, } \\
Q . \text { nuttallii, Q. pagoda, } \\
\text { Q. rubra, Q. shumardii, } \\
\text { Q. stellata, Q. velutina }\end{array}$ & $\begin{array}{l}\text { growth response to } \\
\text { soil moisture }\end{array}$ & 0 & 0.057 & 1 & 12 to 24 & outdoors & $\begin{array}{l}\text { cultured from } \\
\text { seeds }\end{array}$ & yes \\
\hline $\begin{array}{l}\text { Gunatilleke et al. } \\
\text { (1997) }\end{array}$ & $\begin{array}{l}8 \text { species of Shorea } \\
\text { section Doona (Dipte- } \\
\text { rocarpaceae), Sri Lanka }\end{array}$ & $\begin{array}{l}\text { growth response to } \\
\text { nutrient addition }\end{array}$ & 1 to 3 & 0.0053 & 1 & 24 & shade house & $\begin{array}{l}\text { cultured from } \\
\text { seeds }\end{array}$ & no \\
\hline $\begin{array}{l}\text { Tognetti et al. } \\
\text { (1997) }\end{array}$ & Fagus sylvatica & \begin{tabular}{|l|} 
physiological \\
response to light \\
intensity
\end{tabular} & 12 & 0.0025 & 1 & $1(+0.75)$ & $\begin{array}{l}\text { growth } \\
\text { chamber }\end{array}$ & $\begin{array}{l}\text { cultured from } \\
\text { seeds }\end{array}$ & no \\
\hline van Hees (1997) & $\begin{array}{l}\text { Fagus sylvatica, Quercus } \\
\text { robur }\end{array}$ & $\begin{array}{l}\text { growth response to } \\
\text { shading and drought }\end{array}$ & 0 & 0.005 & 5 & 6 & outdoors & $\begin{array}{l}\text { cultured from } \\
\text { seeds }\end{array}$ & no \\
\hline $\begin{array}{l}\text { Wagner } \\
\text { Dreyer (1997) }\end{array}$ & $\begin{array}{l}\text { Quercus petraea, Q. robur, } \\
\text { Q. rubra }\end{array}$ & \begin{tabular}{|l|} 
physiological \\
response to flooding \\
and light intensity \\
\end{tabular} & 0 & 0.005 & 3 & 4 & greenhouse & $\begin{array}{l}\text { cultured from } \\
\text { seeds }\end{array}$ & no \\
\hline $\begin{array}{l}\text { Gravatt and Kirby } \\
\text { (1998) }\end{array}$ & $\begin{array}{l}\text { Quercus alba, Q. nigra, } \\
\text { Fraxinus pennsylvanica, } \\
\text { Nyssa aquatic } \\
\end{array}$ & $\begin{array}{l}\text { physiological } \\
\text { response to flooding }\end{array}$ & 12 & 0.0038 & 1 & $1(+2.75)$ & $\begin{array}{l}\text { growth } \\
\text { chamber }\end{array}$ & $\mathrm{n} / \mathrm{a}$ & no \\
\hline Takahashi (1998) & $\begin{array}{l}\text { Elaeocarpus sylvestris } \\
\text { ellipticus }\end{array}$ & \begin{tabular}{|l|} 
isotopic differences \\
between soil water \\
and stem water
\end{tabular} & $\mathrm{n} / \mathrm{a}$ & 0.0026 & 1 & 0.2 & $\begin{array}{l}\text { growth } \\
\text { chamber }\end{array}$ & $\mathrm{n} / \mathrm{a}$ & no \\
\hline
\end{tabular}




\section{Continuation of Table S1}

\begin{tabular}{|c|c|c|c|c|c|c|c|c|c|}
\hline reference & species & objective & $\begin{array}{l}\text { age } \\
\text { [month] }\end{array}$ & \begin{tabular}{|ll} 
pot & volume \\
{$\left[\mathrm{m}^{3}\right]$} &
\end{tabular} & $\begin{array}{l}\text { plants per } \\
\text { pot }\end{array}$ & \begin{tabular}{|ll} 
Study & duration \\
$(+$ & adaption \\
time $)$ & [months $]$ \\
\end{tabular} & location & plants origin & $\begin{array}{l}\text { additional } \\
\text { in-situ study }\end{array}$ \\
\hline $\begin{array}{l}\text { Tognetti et al. } \\
(1998)\end{array}$ & Fagus sylvatica & \begin{tabular}{|l|} 
physiological \\
response to light \\
intensity
\end{tabular} & 24 & 0.003 & 1 & $x_{2}$ & greenhouse & $\begin{array}{l}\text { cultured from } \\
\text { seeds }\end{array}$ & no \\
\hline $\begin{array}{l}\text { Agyeman et al. } \\
(1999)\end{array}$ & $\begin{array}{l}16 \text { West African tree } \\
\text { species }\end{array}$ & $\begin{array}{l}\text { growth response to } \\
\text { light intensity }\end{array}$ & 0.5 to 1.5 & 0.0034 & 1 & $\min .0 .75$ & shade house & \begin{tabular}{|l|}
$\begin{array}{l}\text { cultured from } \\
\text { seeds }\end{array}$ \\
\end{tabular} & no \\
\hline $\begin{array}{l}\text { Cornelissen et al. } \\
(1999)\end{array}$ & 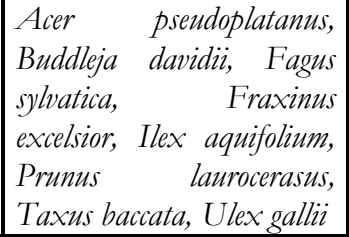 & $\begin{array}{l}\text { growth response to } \\
\text { elevated } \mathrm{CO}_{2}\end{array}$ & 1 & 0.006 & 1 & 2 & outdoors & $\begin{array}{|lr|}\text { cultured from } \\
\text { seeds or } \\
\text { excavated } \\
\text { from natural } \\
\text { stands }\end{array}$ & no \\
\hline \begin{tabular}{lll|}
$\begin{array}{l}\text { Dalling } \\
(1999)\end{array}$ & et & al. \\
\end{tabular} & $\begin{array}{l}\text { a) Luehea seemannii } \\
\text { b) Ochroma pyramidale }\end{array}$ & $\begin{array}{l}\text { growth response to } \\
\text { light intensity }\end{array}$ & 0.5 & 0.008 & 1 & a) 3, b) 2 & outdoors & \begin{tabular}{|l|}
$\begin{array}{l}\text { cultured from } \\
\text { seeds }\end{array}$ \\
\end{tabular} & no \\
\hline $\begin{array}{l}\text { a) Heilmeier et al. } \\
\text { (2000a); } \\
\text { b) Heilmeier et al. } \\
\text { (2000b) }\end{array}$ & $\begin{array}{l}\text { a) Fagus sylvatica, Picea } \\
\text { abies, Sorbus aucuparia } \\
\text { b) Abies alba, Betula } \\
\text { pendula, Fagus sylvativa, } \\
\text { Picea abies }\end{array}$ & $\begin{array}{l}\text { growth response to } \\
\mathrm{S} \text { and } \mathrm{N} \text { deposition }\end{array}$ & 0 & $\mathrm{n} / \mathrm{a}$ & 20 or 50 & 16 & $\begin{array}{l}\text { outdoors } \\
\text { (winter: } \\
\text { greenhouse) }\end{array}$ & $\begin{array}{l}\text { cultured from } \\
\text { seeds }\end{array}$ & no \\
\hline $\begin{array}{l}\text { Löf and Welander } \\
(2000)\end{array}$ & Fagus sylvatica & $\begin{array}{l}\text { growth response to } \\
\text { drought }\end{array}$ & 0 & $\mathrm{n} / \mathrm{a}$ & $\mathrm{n} / \mathrm{a}$ & 10.75 or 14 & $\begin{array}{l}\text { climate } \\
\text { chamber }\end{array}$ & \begin{tabular}{|l|} 
self cultured \\
from seeds
\end{tabular} & no \\
\hline Wölfle et al. (2000) & Picea abies & $\begin{array}{l}\begin{array}{l}\text { growth response to } \\
\text { nutrients }\end{array} \\
\end{array}$ & 24 & 0.04 & 2 & $48(+15)$ & outdoors & \begin{tabular}{|l|}
$\begin{array}{l}\text { clonal plants } \\
\text { (plugs) }\end{array}$ \\
\end{tabular} & no \\
\hline $\begin{array}{l}\text { Aspelmeier (2001); } \\
\text { Aspelmeier and } \\
\text { Leuschner (2006) }\end{array}$ & Betula pendula & $\begin{array}{l}\text { genotypic variation } \\
\text { in drought response }\end{array}$ & 6 to 12 & 0.045 & 1 & 3 & outdoors & $\begin{array}{l}\text { propagated } \\
\text { from tissue } \\
\text { cultures }\end{array}$ & no \\
\hline $\begin{array}{l}\text { Bellingham et al. } \\
(2001)\end{array}$ & $\begin{array}{|lr|}\text { Griselinia } & \text { littoralis, } \\
\text { Metrosideros r umbellata, } & \text { Weinmannia racemosa } \\
\end{array}$ & $\begin{array}{l}\text { effect of nitrogen } \\
\text { fixing shrub on tree } \\
\text { growth }\end{array}$ & 12 & 0.001 & 1 & 12 & greenhouse & $\begin{array}{|lr|}\text { cultured } & \text { from } \\
\text { seeds } & \text { and } \\
\text { cuttings } & \\
\end{array}$ & yes \\
\hline Baum et al. (2002) & Populus trichocarpa & $\begin{array}{l}\begin{array}{l}\text { growth response to } \\
\text { mycorrhiza }\end{array} \\
\end{array}$ & 12 & $\mathrm{n} / \mathrm{a}$ & 1 & 6 & greenhouse & \begin{tabular}{|l|}
$\begin{array}{l}\text { cultured from } \\
\text { cuttings }\end{array}$ \\
\end{tabular} & yes \\
\hline Huat et al. (2002) & Azadirachta excelsa & $\begin{array}{l}\text { growth and physio- } \\
\text { logical response to } \\
\text { fertilization and } \\
\text { mycorrhiza }\end{array}$ & 6 & 0.0077 & 1 & 4 & greenhouse & $\begin{array}{l}\text { cultured from } \\
\text { seeds }\end{array}$ & no \\
\hline
\end{tabular}




\section{Continuation of Table S1}

\begin{tabular}{|c|c|c|c|c|c|c|c|c|c|}
\hline reference & species & objective & $\begin{array}{l}\text { age } \\
\text { [month] }\end{array}$ & \begin{tabular}{|ll} 
pot & volume \\
{$\left[\mathrm{m}^{3}\right]$} &
\end{tabular} & $\begin{array}{l}\text { plants per } \\
\text { pot }\end{array}$ & $\begin{array}{|ll|}\begin{array}{ll}\text { Study } & \text { duration } \\
(+ & \text { adaption } \\
\text { time }) & {[\text { months }}\end{array} \\
\end{array}$ & location & plants origin & $\begin{array}{l}\text { additional } \\
\text { in-situ study }\end{array}$ \\
\hline $\begin{array}{l}\text { Rogers and } \\
\text { Siemann (2002) }\end{array}$ & $\begin{array}{l}\text { Celtis laevigata, Sapium } \\
\text { sebiferum }\end{array}$ & $\begin{array}{l}\text { growth response to } \\
\text { herbivory and } \\
\text { resource availability }\end{array}$ & 2 & 0.00765 & 1 & 3.5 & outdoors & $\begin{array}{l}\text { cultured from } \\
\text { seeds }\end{array}$ & no \\
\hline $\begin{array}{l}\text { Valladares et al. } \\
(2002)\end{array}$ & $\begin{array}{l}\text { Fagus sylvatica, Quercus } \\
\text { robur }\end{array}$ & \begin{tabular}{|l|} 
physiological \\
response to light \\
intensity
\end{tabular} & 24 & 0.04 & $\mathrm{n} / \mathrm{a}$ & 4 & $\mathrm{n} / \mathrm{a}$ & nursery & no \\
\hline $\begin{array}{l}\text { Weber-Blaschke } \\
\text { and Rehfuess } \\
(2002) ; \\
\text { Weber-Blaschke et } \\
\text { al. (2002) }\end{array}$ & $\begin{array}{l}\text { Acer psendoplatanus, } \\
\text { Fraxinus excelsior }\end{array}$ & $\begin{array}{l}\text { growth response to } \\
\text { different nutrients }\end{array}$ & 12 & 0.02 & 3 & 18 & greenhouse & nursery & no \\
\hline $\begin{array}{l}\text { Weih and Nordh } \\
(2002) \text {; Weih and } \\
\text { Nordh (2005) }\end{array}$ & $\begin{array}{l}14 \text { Salix clones of different } \\
\text { species }\end{array}$ & $\begin{array}{|lr|}\text { physiological } & \text { and } \\
\text { growth } & \text { response to } \\
\text { different } & \text { light } \\
\text { intensity } & \text { and } \\
\text { nutrient availability }\end{array}$ & $\mathrm{n} / \mathrm{a}$ & 0.001 & 1 & 1,3 , or 6 & outdoors & $\begin{array}{l}\text { cultured from } \\
\text { cuttings }\end{array}$ & yes \\
\hline Ammer (2003) & $\begin{array}{l}\text { Fagus sylvatica, Quercus } \\
\text { robur }\end{array}$ & $\begin{array}{|lr|}\text { growth } & \text { response } \\
\text { and } & \text { biomass } \\
\text { allocation to shading } \\
\end{array}$ & 12 & 0.002 & 1 & 4.5 & outdoors & nursery & no \\
\hline Chan et al. (2003) & $\begin{array}{l}\text { Alnus rubra, Pseudotsuga } \\
\text { menziesii }\end{array}$ & \begin{tabular}{|l|} 
growth response to \\
light intensity and \\
soil moisture, \\
biomass allocation
\end{tabular} & 12 & 0.2 & 1 & 36 & outdoors & $\mathrm{n} / \mathrm{a}$ & no \\
\hline Loh et al. (2003) & Ficus benjamina & $\begin{array}{l}\text { growth response to } \\
\text { limited soil volume } \\
\text { and soil dilution }\end{array}$ & $\mathrm{n} / \mathrm{a}$ & 0.011 or 0.054 & $\mathrm{n} / \mathrm{a}$ & 5,10, or $15(+0.5)$ & greenhouse & $\begin{array}{l}\text { clonal plants } \\
\text { (plugs) }\end{array}$ & no \\
\hline $\begin{array}{l}\text { Rogers and } \\
\text { Siemann (2003) }\end{array}$ & \begin{tabular}{|l|l|} 
Sapium sebiferum (in the \\
presence of grass \\
vegetation)
\end{tabular} & $\begin{array}{l}\text { growth response to } \\
\text { herbivory and } \\
\text { resource availability }\end{array}$ & 1 & 0.009 & 1 & 3.5 & greenhouse & $\begin{array}{l}\text { cultured from } \\
\text { seeds }\end{array}$ & yes \\
\hline
\end{tabular}




\section{Continuation of Table S1}

\begin{tabular}{|c|c|c|c|c|c|c|c|c|c|}
\hline reference & species & objective & $\begin{array}{l}\text { age } \\
\text { [month] }\end{array}$ & $\begin{array}{ll}\text { pot } & \text { volume } \\
{\left[\mathrm{m}^{3}\right]} & \end{array}$ & $\begin{array}{l}\text { plants per } \\
\text { pot }\end{array}$ & $\begin{array}{ll}\text { Study } & \text { duration } \\
(+ & \text { adaption } \\
\text { time }) & \text { [months] } \\
\end{array}$ & location & plants origin & $\begin{array}{l}\text { additional } \\
\text { in-situ study }\end{array}$ \\
\hline $\begin{array}{l}\text { Blair and Perfecto } \\
\text { (2004) }\end{array}$ & $\begin{array}{lr}\text { Albiriarariapele, } \\
\text { Cedrelar odorata, Ceiba } \\
\text { pentandra, } \\
\text { alliodora, Dalbergia retusa, } \\
\text { Gliricidia sepium, } \\
\text { Swietenia macrophylla } \\
\end{array}$ & $\begin{array}{l}\text { growth response to } \\
\text { soil phosphate }\end{array}$ & 0 & $\begin{array}{l}\mathrm{n} / \mathrm{a} \\
(\mathrm{d}=21 \mathrm{~cm})\end{array}$ & 1 & 5 & greenhouse & $\begin{array}{l}\text { cultured from } \\
\text { seeds }\end{array}$ & no \\
\hline Dehlin et al. (2004) & $\begin{array}{l}\text { Betula pendula, Picea } \\
\text { abies, Pinus sylvestris }\end{array}$ & $\begin{array}{l}\text { growth response to } \\
\text { shading and humus } \\
\text { fertility, competition, } \\
\text { and mycorrhiza }\end{array}$ & 1 & 0.0002 & 2 or 4 & 6 & $\begin{array}{l}\text { climate } \\
\text { chamber }\end{array}$ & $\begin{array}{l}\text { cultured from } \\
\text { seeds }\end{array}$ & no \\
\hline Silva et al. (2004) & Eucalyptus globulus & $\begin{array}{l}\text { growth and physio- } \\
\text { logical response to } \\
\text { drought }\end{array}$ & 12 & 0.01 & 1 & 2 & greenhouse & $\begin{array}{l}\text { cultured from } \\
\text { cuttings }\end{array}$ & no \\
\hline $\begin{array}{l}\text { Alaoui-Sossé et al. } \\
(2005)\end{array}$ & Quercus robur & $\begin{array}{l}\text { growth response to } \\
\text { flooding }\end{array}$ & 0.5 & 0.0025 & 1 & $0.5,1$, or 1.8 & $\begin{array}{l}\begin{array}{l}\text { growth } \\
\text { chamber }\end{array} \\
\end{array}$ & $\begin{array}{l}\text { cultured from } \\
\text { seeds }\end{array}$ & no \\
\hline $\begin{array}{l}\text { Osunkoya et al. } \\
(2005)\end{array}$ & $\begin{array}{l}\text { Acacia mangium, } \\
\text { Melastoma beccarianum }\end{array}$ & $\begin{array}{l}\text { growth response to } \\
\text { light intensity, } \\
\text { competition }\end{array}$ & 1 & 0.005 & $\begin{array}{l}2,6,8,10 \\
12, \text { or } 14\end{array} \mid$ & 6 & $\begin{array}{l}\text { outdoors and } \\
\text { greenhouse }\end{array}$ & $\begin{array}{l}\text { excavated } \\
\text { from natural } \\
\text { stands } \\
\end{array}$ & no \\
\hline Otieno et al. (2005) & Acacia $\quad$ tortilis, & \begin{tabular}{|ll} 
physiological and \\
morphological res- \\
ponses to drought \\
\end{tabular} & 4 & 0.027 & 1 & 12 & greenhouse & $\begin{array}{l}\text { cultured from } \\
\text { seeds }\end{array}$ & no \\
\hline $\begin{array}{l}\text { Saxe and Kerstiens } \\
(2005)\end{array}$ & $\begin{array}{l}\text { Fagus sylvatica, Fraxinus } \\
\text { excelsior }\end{array}$ & $\begin{array}{l}\text { climate change, } \\
\text { competition }\end{array}$ & 1 & $\begin{array}{l}\text { a) } 0.00028, \\
\text { b) } 0.001\end{array}$ & $\begin{array}{l}\text { a) } 1 \text { or } 2, \\
\text { b) } 2\end{array}$ & 4 & $\begin{array}{l}\text { outdoors and } \\
\text { growth } \\
\text { chamber }\end{array}$ & $\begin{array}{l}\text { cultured from } \\
\text { seeds }\end{array}$ & no \\
\hline Sell et al. (2005) & $\begin{array}{l}\text { Populus canadensis, Salix } \\
\text { viminalis }\end{array}$ & $\begin{array}{l}\text { effect of mycorrhiza } \\
\text { on cadmium uptake }\end{array}$ & $\mathrm{n} / \mathrm{a}$ & 0.0015 & 1 & 2.75 & greenhouse & $\begin{array}{l}\text { cultured from } \\
\text { cuttings }\end{array}$ & no \\
\hline $\begin{array}{l}\text { Tanner et al. } \\
(2005)\end{array}$ & $\begin{array}{ll}\text { Dryobalanops } & \text { lanceolata, } \\
\text { Hopea sp., } & \text { Parashorea } \\
\text { malaanonan, P. } & \text { tomentella, } \\
\text { Shorea } & \text { beccariana, } \\
\text { S. fallax, S. } & \text { falciferoides } \\
\text { ssp.glaucescens, } & \\
\text { S. johorensis, S. leprosula, } \\
\text { S. seminis }\end{array}$ & $\begin{array}{l}\text { growth response to } \\
\text { competition }\end{array}$ & 10 & 0.0028 & 2 & 22 & shade house & $\begin{array}{l}\text { cultured from } \\
\text { seeds }\end{array}$ & no \\
\hline
\end{tabular}




\section{Continuation of Table S1}

\begin{tabular}{|c|c|c|c|c|c|c|c|c|c|}
\hline reference & species & objective & $\begin{array}{l}\text { age } \\
\text { [month] }\end{array}$ & \begin{tabular}{|ll} 
pot & volume \\
{$\left[\mathrm{m}^{3}\right]$} &
\end{tabular} & $\begin{array}{l}\text { plants per } \\
\text { pot }\end{array}$ & \begin{tabular}{|lr} 
Study & duration \\
$(+$ & adaption \\
time $)$ & [months] \\
\end{tabular} & location & plants origin & $\begin{array}{l}\text { additional } \\
\text { in-situ study }\end{array}$ \\
\hline $\begin{array}{l}\text { Baraloto et al. } \\
(2005) \text {, Baraloto et } \\
\text { al. (2006) }\end{array}$ & \begin{tabular}{|lr} 
Dicorynia & guianensis, \\
Eperua & falcate, \\
E. grandiflora, Goupia \\
glabra, Jacaranda copaia, \\
Qualea rosea, Recordoxylon \\
speciosum, Sextonia rubra, \\
Virola michelii \\
\end{tabular} & $\begin{array}{|lr|}\text { growth response to } \\
\text { soil resource } \\
\text { availability }\end{array}$ & 0.75 & 0.006 & 1 & 12 & shade house & $\begin{array}{l}\text { cultured from } \\
\text { seeds }\end{array}$ & yes \\
\hline Parelle et al. (2006) & Quercus petraea, Q. robur & $\begin{array}{l}\text { physiological and } \\
\text { morphological res- } \\
\text { ponses to flooding }\end{array}$ & 4 & 0.004 & 1 & 1.75 & greenhouse & $\begin{array}{l}\text { cultured from } \\
\text { seeds }\end{array}$ & no \\
\hline Sanon et al. (2006) & Gmelina arborea & $\begin{array}{l}\text { growth response to } \\
\text { mycorrhiza }\end{array}$ & 1 & $\begin{array}{|ll|}\text { a) } & 0.001, \\
\text { b) } 0.05 & \\
\end{array}$ & 1 & a) 4, b) 12 & greenhouse & $\begin{array}{l}\begin{array}{l}\text { cultured from } \\
\text { seeds }\end{array} \\
\end{array}$ & no \\
\hline Zou et al. (2006) & Sapium sebiferum & $\begin{array}{l}\text { effect of Chinese } \\
\text { tallow tree on soil- } \\
\text { plant system }\end{array}$ & 1 & 0.0065 & 1 & 4 & shade house & $\begin{array}{l}\text { cultured from } \\
\text { seeds }\end{array}$ & no \\
\hline $\begin{array}{l}\text { Aranda et al. } \\
(2007)\end{array}$ & Quercus suber & $\begin{array}{l}\text { interaction of light } \\
\text { and water on water- } \\
\text { use-efficiency }\end{array}$ & 12 & 0.003 & 1 & 3 & greenhouse & $\begin{array}{l}\text { cultured from } \\
\text { seeds }\end{array}$ & no \\
\hline Meier (2007) & Fagus sylvatica & $\begin{array}{l}\text { growth response to } \\
\text { drought, genotypic } \\
\text { variation }\end{array}$ & 48 & 7.1 & 4 & $21(+7)$ & outdoors & $\begin{array}{l}\text { excavated } \\
\text { from natural } \\
\text { stands } \\
\end{array}$ & yes \\
\hline $\begin{array}{l}\text { a) Schumacher } \\
\text { (2007; } \\
\text { b) Schumacher et } \\
\text { al. (2008) }\end{array}$ & $\begin{array}{l}\text { different experiments } \\
\text { with up to } 14 \text { tropical } \\
\text { tree species }\end{array}$ & $\begin{array}{l}\text { growth response to } \\
\text { drought and shade }\end{array}$ & 3 to 6 & 0.001 & 1 & a) 6.5 , b) 4 & outdoors & $\begin{array}{l}\text { cultured from } \\
\text { seeds and } \\
\text { excavated } \\
\text { from natural } \\
\text { stands }\end{array}$ & yes \\
\hline $\begin{array}{l}\text { Willoughby et al. } \\
\text { (2007) }\end{array}$ & $\begin{array}{l}\text { Alnus glutinosa, Carpinus } \\
\text { betulus, Cornus sanguinea, } \\
\text { Fraxinus excelsior, Prunus } \\
\text { spinosa, Sorbus aria }\end{array}$ & $\begin{array}{l}\text { tolerance } \\
\text { herbicides }\end{array}$ & 0 & 0.001 & \begin{tabular}{|l|}
$16, \quad 19$, \\
or 20 \\
(depending \\
on species)
\end{tabular} & $\mathrm{n} / \mathrm{a}$ & greenhouse & $\begin{array}{l}\text { cultured from } \\
\text { seeds }\end{array}$ & no \\
\hline $\begin{array}{l}\text { Železnik et al. } \\
(2007)\end{array}$ & Fagus sylvatica & 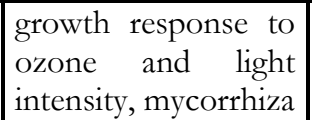 & 24 & 0.03 & 6 & 18 & outdoors & nursery & no \\
\hline
\end{tabular}




\section{Continuation of Table S1}

\begin{tabular}{|c|c|c|c|c|c|c|c|c|c|}
\hline reference & species & objective & $\begin{array}{l}\text { age } \\
\text { [month] }\end{array}$ & \begin{tabular}{|ll} 
pot & volume \\
{$\left[\mathrm{m}^{3}\right]$} &
\end{tabular} & $\begin{array}{l}\text { plants per } \\
\text { pot }\end{array}$ & $\begin{array}{ll}\text { Study } & \text { duration } \\
(+ & \text { adaption } \\
\text { time }) & \text { [months] } \\
\end{array}$ & location & plants origin & \begin{tabular}{|l} 
additional \\
in-situ study
\end{tabular} \\
\hline Hata et al. (2010) & $\begin{array}{l}\text { Casuarina equisetifolia, } \\
\text { Schima mertensiana }\end{array}$ & $\begin{array}{l}\text { growth response to } \\
\text { exotic species litter, } \\
\text { germination }\end{array}$ & 0 & 0.0041 & 300 & 2 & greenhouse & $\begin{array}{l}\text { cultured from } \\
\text { seeds }\end{array}$ & yes \\
\hline $\begin{array}{l}\text { Jensen and Hansen } \\
(2010)\end{array}$ & $\begin{array}{ll}\text { Quercus } & \text { robur } \\
\text { (18 provenances from } \\
\text { northern Europe and } \\
20 \text { Danish open-polli- } \\
\text { nated families) }\end{array}$ & $\begin{array}{l}\text { growth responses to } \\
\text { soil water, genetic } \\
\text { variation }\end{array}$ & 0 & 1.728 & 114 & 11 & greenhouse & $\begin{array}{l}\text { cultured from } \\
\text { seeds }\end{array}$ & no \\
\hline Li et al. (2010) & $\begin{array}{l}\text { Pinus massoniana, } \\
\text { Camellia oleifera, Cyclo- } \\
\text { balanopsis glauca, Elaeo- } \\
\text { carpus japonicas, Lithocar- } \\
\text { pus glaber, Quercus } \\
\text { glandulifera, Q. variabilis, } \\
\text { Rhus chinensis }\end{array}$ & $\begin{array}{l}\text { growth response to } \\
\text { competition }\end{array}$ & 0 & 0.045 & 4 & 7,19 , or 31 & $\mathrm{n} / \mathrm{a}$ & $\begin{array}{l}\text { cultured from } \\
\text { seeds }\end{array}$ & no \\
\hline $\begin{array}{l}\text { Mangan et al. } \\
(2010)\end{array}$ & \begin{tabular}{|lr} 
Beilschmiedia & pendula, \\
Brosimum alicastrum, & nesiotica, \\
Eugeniar & panamensis, \\
Lacmellear panamensis, & Tetragastris pansis \\
Virola surinamensis
\end{tabular} & $\begin{array}{l}\text { negative plant-soil } \\
\text { feedback mediated } \\
\text { by soil biota }\end{array}$ & 1 & 0.004 & 1 & 5 & shade house & $\begin{array}{l}\text { cultured from } \\
\text { seeds }\end{array}$ & yes \\
\hline $\begin{array}{l}\text { Mielke and } \\
\text { Schaffer (2010) }\end{array}$ & Eugenia uniflora & $\begin{array}{l}\text { physiological res- } \\
\text { ponse to light inten- } \\
\text { sity and flooding }\end{array}$ & 18 & 0.01 & 10 to 12 & $1(+6)$ & $\mathrm{n} / \mathrm{a}$ & nursery & no \\
\hline Jung (2008) & $\begin{array}{l}\text { a) Betula pendula, } \\
\text { Quercus robur } \\
\text { b) Pinus sylvestris }\end{array}$ & $\begin{array}{l}\text { growth response to } \\
\text { insect faeces }\end{array}$ & a) 12 , b) 24 & 0.012 & 1 & 36 & outdoors & nursery & yes \\
\hline $\begin{array}{l}\text { Toledo-Aceves } \\
\text { and Swaine (2008) }\end{array}$ & $\begin{array}{l}\text { Acaciar kamerunensis, } \\
\text { Garcinia afzelii, Khaya } \\
\text { anthotheca, Nauclea } \\
\text { diderrichii }\end{array}$ & $\begin{array}{l}\text { growth response to } \\
\text { light intensity, } \\
\text { competition }\end{array}$ & 4 & $\begin{array}{ll}\text { a) } & 0.019 \text {, } \\
\text { b) } 0.038 & \end{array}$ & a) 1, b) 2 & 12 & shade house & $\begin{array}{l}\text { cultured from } \\
\text { seeds }\end{array}$ & no \\
\hline
\end{tabular}




\section{Continuation of Table S1}

\begin{tabular}{|c|c|c|c|c|c|c|c|c|c|}
\hline reference & species & objective & $\begin{array}{l}\text { age } \\
\text { [month] }\end{array}$ & $\begin{array}{ll}\text { pot } & \text { volume } \\
{\left[\mathrm{m}^{3}\right]} & \end{array}$ & $\begin{array}{l}\text { plants per } \\
\text { pot }\end{array}$ & 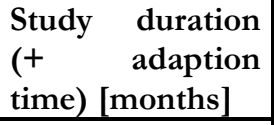 & location & plants origin & $\begin{array}{l}\text { additional } \\
\text { in-situ study }\end{array}$ \\
\hline Zou et al. (2008) & Sapium sebiferum & $\begin{array}{l}\text { competitive ability } \\
\text { and herbivory } \\
\text { tolerance of Chinese } \\
\text { tallow tree }\end{array}$ & 1 & 0.0065 & 2 & 4 & shade house & $\begin{array}{l}\text { cultured from } \\
\text { seeds }\end{array}$ & no \\
\hline Haase (2009) & \begin{tabular}{|l|} 
Fagus sylvatica, Fraxinus \\
excelsior, Quercus petraea, \\
Picea abies, Pinus \\
sylvestris, Tilia cordata \\
\end{tabular} & $\begin{array}{l}\text { growth response to } \\
\text { species diversity, } \\
\text { composition, and } \\
\text { density }\end{array}$ & 12 to 36 & 0.13 & 6 or 12 & 24 & outdoors & nursery & yes \\
\hline $\begin{array}{l}\text { Reubens et al. } \\
(2009)\end{array}$ & $\begin{array}{l}\text { Quercus robur, Robinia } \\
\text { pseudoacacia }\end{array}$ & $\begin{array}{l}\text { growth response to } \\
\text { mechanical } \\
\text { stimulation }\end{array}$ & 12 & 0.0069 & 1 & 4 & greenhouse & nursery & no \\
\hline Rose et al. (2009) & Fagus sylvatica & $\begin{array}{l}\text { growth response to } \\
\text { drought, genotypic } \\
\text { variation }\end{array}$ & 1 & 0.002 & 1 & 4 & outdoors & $\begin{array}{l}\text { cultured from } \\
\text { seeds }\end{array}$ & no \\
\hline $\begin{array}{l}\text { Hashim and } \\
\text { Hughes (2010) }\end{array}$ & $\begin{array}{|lr|}\text { Glochidion } & \text { obscurum, } \\
\text { Lagerstroemia } & \text { speciosa, } \\
\text { Vitex pinnata } & \\
\end{array}$ & $\begin{array}{l}\text { growth response to } \\
\text { nutrient addition }\end{array}$ & 4 & 0.0031 & 1 & 2 & outdoors & $\begin{array}{l}\text { cultured from } \\
\text { seeds }\end{array}$ & no \\
\hline Yan et al. (2010) & $\begin{array}{|lr|}\text { Armeniacaririsa, } & \text { sibirica } \\
\text { Quercus } & \text { liaotungensis, } \\
\text { Robinia psendoacacia, } & \\
\text { Syringa oblata }\end{array}$ & $\begin{array}{l}\text { physiological } \\
\text { response to drought }\end{array}$ & 16 & 0.0038 & 1 & 1.5 & greenhouse & $\begin{array}{l}\text { cultured from } \\
\text { seeds }\end{array}$ & no \\
\hline Zeugin (2010) & $\begin{array}{|lr|}\text { Anacardium } & \text { excelsum, } \\
\text { Luehea } & \text { seemannii, } \\
\text { Tabebuia rosea } & \\
\end{array}$ & $\begin{array}{l}\text { effects of tree diver- } \\
\text { sity and competition } \\
\text { on nutrient uptake }\end{array}$ & $\mathrm{n} / \mathrm{a}$ & 0.75 & 3 & 23 & outdoors & nursery & yes \\
\hline $\begin{array}{l}\text { Zhang et al. (2010); } \\
\text { Zhang et al. (2012) }\end{array}$ & $\begin{array}{l}\text { Cunninghamiranceolata, } \\
\text { Liriodendron chinense, } \\
\text { Pinus massoniana, Schima } \\
\text { superb }\end{array}$ & $\begin{array}{l}\text { growth response to } \\
\text { nutrient availability, } \\
\text { light intensity, and } \\
\text { competition }\end{array}$ & 0.3 & 0.017 & 1 & 6 & $\begin{array}{l}\text { semi-open } \\
\text { greenhouse }\end{array}$ & $\begin{array}{l}\text { cultured from } \\
\text { seeds }\end{array}$ & no \\
\hline $\begin{array}{l}\text { Armas and } \\
\text { Pugnaire (2011) }\end{array}$ & $\mid \begin{array}{lr}\text { Olea europaea, Pinus } \\
\text { halepensis, } \\
\text { coccifera, Q. } \text {. suber }\end{array}$ & $\begin{array}{l}\text { effect of below- } \\
\text { ground competition } \\
\text { on growth/biomass } \\
\text { allocation }\end{array}$ & 24 & 0.0003 & 1 or 2 & 12 & outdoors & $\begin{array}{l}\text { cultured from } \\
\text { seeds }\end{array}$ & No \\
\hline
\end{tabular}




\section{Continuation of Table S1}

\begin{tabular}{|c|c|c|c|c|c|c|c|c|c|}
\hline reference & species & objective & $\begin{array}{l}\text { age } \\
\text { [month] }\end{array}$ & \begin{tabular}{|ll} 
pot & volume \\
{$\left[\mathrm{m}^{3}\right]$} &
\end{tabular} & $\begin{array}{l}\text { plants per } \\
\text { pot }\end{array}$ & $\begin{array}{ll}\text { Study } & \text { duration } \\
(+ & \text { adaption } \\
\text { time }) & \text { [months }] \\
\end{array}$ & location & plants origin & $\begin{array}{l}\text { additional } \\
\text { in-situ study }\end{array}$ \\
\hline $\begin{array}{l}\text { Kohout et al. } \\
\text { (2011) }\end{array}$ & $\begin{array}{|lrr|}\text { Pinus } & \text { strobus, } & \text { Pinus } \\
\text { sylvestris, } & \text { Vaccinium } \\
\text { myrtillus, } & \text { Vaccinium } & \text { vitis- } \\
\text { idaea } & \end{array}$ & effect of mycorrhiza & 0 & 0.0015 & 5 & 29 & outdoors & $\begin{array}{l}\text { cultured from } \\
\text { seeds }\end{array}$ & no \\
\hline Coq et al. (2012) & $\begin{array}{l}\text { Goupia glabra, Hymenaea } \\
\text { courbaril, Platonia insignis, } \\
\text { Vocbysia tomentosa }\end{array}$ & $\begin{array}{l}\text { growth response to } \\
\text { decomposing litter }\end{array}$ & 5 & 0.0055 & 1 & 14.5 & greenhouse & $\begin{array}{l}\text { cultured from } \\
\text { seeds }\end{array}$ & no \\
\hline Daud et al. (2012) & Hevea brasiliensis & $\begin{array}{l}\text { physiological } \\
\text { response to insect }\end{array}$ & 5 & 0.002 & 1 & 5 & greenhouse & nursery & no \\
\hline Ding et al. (2012) & \begin{tabular}{|l|} 
Quercus acutissima, \\
Robinia psendoacacia
\end{tabular} & $\begin{array}{l}\begin{array}{l}\text { growth response to } \\
\text { nitrogen deposition }\end{array} \\
\end{array}$ & 2 & 0.011 & 2 & 3 & greenhouse & $\begin{array}{l}\begin{array}{l}\text { cultured from } \\
\text { seeds }\end{array} \\
\end{array}$ & no \\
\hline Schall et al. (2012) & $\begin{array}{l}\text { a) Fagus sylvatica, } \\
\text { b) Picea abies }\end{array}$ & $\begin{array}{l}\text { growth response to } \\
\text { shade and drought, } \\
\text { biomass allocation }\end{array}$ & $\begin{array}{l}\text { a) } 1 \\
\text { b) } 2\end{array}$ & 0.03 & 1 & 31 & greenhouse & nursery & no \\
\hline $\begin{array}{l}\text { Kawaletz et al. } \\
(2013)\end{array}$ & $\begin{array}{|lr|}\text { Quercus robur, } & \text { Carpinus } \\
\text { betulus, } & \text { Robinia } \\
\text { pseudoacacia, } & \text { Prunus } \\
\text { serotina } & \end{array}$ & $\begin{array}{l}\text { growth response to } \\
\text { competition, } \\
\text { biomass allocation }\end{array}$ & 12 & 0.065 & 4 & 18 & outdoors & nursery & no \\
\hline
\end{tabular}




\section{References of Table S1}

Agyeman, V., Swaine, M. and Thompson, J. 1999 Responses of tropical forest tree seedlings to irradiance and the derivation of a light response index. J. Ecol. 87: 815-827.

Alaoui-Sossé, B., Gérard, B., Binet, P., Toussaint, M.-L. and Badot, P.-M. 2005 Influence of flooding on growth, nitrogen availability in soil, and nitrate reduction of young oak seedlings (Quercus robur L.). Ann. For. Sci. 62: 593-600.

Ammer, C. 2003 Growth and biomass partitioning of Fagus sylvatica L. and Quercus robur L. seedlings in response to shading and small changes in the R/FR-ratio of radiation. Ann. For. Sci. 60: 163-171.

Amundson, R., Kohut, R. and Laurence, J. 1995 Influence of foliar N on foliar soluble sugars and starchs of red spruce saplings exposed to ambient and elevated ozone. Tree Physiol. 15: 167_ 174.

Aranda, I., Pardos, M., Puértolas, J., Jiménez, M.D. and Pardos, J.A. 2007 Water-use efficiency in cork oak (Quercus suber) is modified by the interaction of water and light availabilities. Tree Physiol. 27: 671-677.

Armas, C. and Pugnaire, F.I. 2011 Plant neighbour identity matters to belowground interactions under controlled conditions. PLoS One 6: 1-7.

Aspelmeier, S. 2001 Genotypic variation in drought response of silver birch (Betula pendula Roth). Dissertation, University of Göttingen.

Aspelmeier, S. and Leuschner, C. 2006 Genotypic variation in drought response of silver birch (Betula pendula Roth): leaf and root morphology and carbon partitioning. Trees 20: 42-52.

Baraloto, C., Bonal, D. and Goldberg, D.E. 2006 Differential seedling growth response to soil resource availability among nine neotropical tree species. J. Trop. Ecol. 22: 487-497.

Baraloto, C., Goldberg, D.E. and Bonal, D. 2005 Performance trade-offs among tropical tree seedlings in contrasting microhabitats. Ecology 86: 2461-2472.

Barnes, J., Pfirrmann, T., Steiner, K., Lütz, C., Busch, U., Küchenhoff, H. and Payer, H.-D. 1995 Effects of elevated $\mathrm{CO}_{2}$, elevated $\mathrm{O}_{3}$ and potassium deficiency on Norway spruce [Picea abies (L) Karst]: Seasonal changes in photosynthesis and non-structural carbohydrate content. Plant Cell Environ. 18: 1345-1357. 
Baum, C., Stetter, U. and Makeschin, F. 2002 Growth response of Populus trichocarpa to inoculation by the ectomycorrhizal fungus Laccaria laccata in a pot and a field experiment. For. Ecol. Manag. 163: 1-8.

Beadle, N. 1962 Soil phosphate and the delimitation on plant communities in Eastern Australia II. Ecology 43: 281-288.

Bellingham, P., Walker, L. and Wardle, D. 2001 Differential facilitation by a nitrogen-fixing shrub during primary succession influences relative performance of canopy tree species. J. Ecol. 89: $861-875$.

Blair, B. and Perfecto, I. 2004 Successional status and root foraging for phosphorus in seven tropical tree species. Can. J. For. Res. 34: 1128-1135.

Bongarten, B.C. and Teskey, R.O. 1987 Dry weight partitioning and its relationship to productivity in Loblolly pine seedlings from seven sources. Forest Sci. 33: 255-267.

Bunce, J. 1992 Stomatal conductance, photosynthesis and respiration of temperate deciduous tree seedlings grown outdoors at an elevated concentration of carbon dioxide. Plant Cell Environ. 15: 541-549.

Chan, S.S., Radosevich, S.R. and Grotta, A.T. 2003 Effects of contrasting light and soil moisture availability on the growth and biomass allocation of Douglas-fir and red alder. Can. J. For. Res. 33: 106-117.

Colin-Belgrand, M., Dreyer, E. and Biron, P. 1991 Sensitivity of seedlings from different oak species to waterlogging: effects on root growth and mineral nutrition. Ann. Sci. For. 48: 193-204.

Coq, S., Weigel, J., Bonal, D. and Haettenschwiler, S. 2012 Litter mixture effects on tropical tree seedling growth - a greenhouse experiment. Plant Biol. 14: 630-640.

Cornelissen, J., Carnelli, A. and Callaghan, T. 1999 Generalities in the growth, allocation and leaf quality responses to elevated $\mathrm{CO}_{2}$ in eight woody species. New Phytol. 141: 401-409.

Curtis, P.S. and Teeri, J.A. 1992 Seasonal responses of leaf gas exchange to elevated carbon dioxide in Populus grandidentata. Can. J. For. Res. 22: 1320-1325.

Dalling, J., Lovelock, C. and Hubbell, S. 1999 Growth responses of seedlings of two neotropical pioneer species to simulated forest gap environments. J. Trop. Ecol. 15: 827-839.

Daud, R.D., Cássia Conforto, E. and Feres, R.J.F. 2012 Changes in leaf physiology caused by Calacarus heveae (Acari, Eriophyidae) on rubber tree. Exp. Appl. Acarol. 57: 127-137. 
Dehlin, H., Nilsson, M.-C., Wardle, D.A. and Shevtsova, A. 2004 Effects of shading and humus fertility on growth, competition, and ectomycorrhizal colonization of boreal forest tree seedlings. Can. J. For. Res. 34: 2573-2586.

Ding, W., Wang, R., Yuan, Y., Liang, X. and Liu, J. 2012 Effects of nitrogen deposition on growth and relationship of Robinia pseudoacacia and Quercus acutissima seedlings. Dendrobiology 67: 3-13.

Fetcher, N., Jaeger, C.H., Strain, B.R. and Sionit, N. 1988 Long-term elevation of atmospheric $\mathrm{CO}_{2}$ concentration and the carbon exchange rates of saplings of Pinus taeda L. and Liquidambar styraciflua L. Tree Physiol. 4: 255-262.

Gonzáles Cascón, M., Alcubilla, M. and Rehfuess, K. 1989: Development of silver fir seedlings (Abies alba Mill.) as dependent on the base saturation of the substratum. Allg. Forst Jagdrtg. 160: $233-241$.

Gravatt, D.A. and Kirby, C.J. 1998 Patterns of photosynthesis and starch allocation in seedlings of four bottomland hardwood tree species subjected to flooding. Tree Physiol. 18: 411-417.

Grulke, N.E., Hom, J.L. and Roberts, S.W. 1993 Physiological adjustment of two full-sib families of ponderosa pine to elevated $\mathrm{CO}_{2}$. Tree Physiol. 12: 391-401.

Gunatilleke, C.V.S., Gunatilleke, I.A.U.N., Perera, G.A.D., Burslem, D.F.R.P., Ashton, P.M.S. and Ashton, P.S. 1997 Responses to nutrient addition among seedlings of eight closely related species of Shorea in Sri Lanka. J. Ecol. 85: 301-311.

Haase, J.U. 2009 Biodiversity and ecosystem functioning: The effects of tree and litter diversity. Dissertation, University of Zurich.

Hashim, N.R. and Hughes, F.M.R. 2010 The responses of secondary forest tree seedlings to soil enrichment in Peninsular Malaysia: an experimental approach. Trop. Ecol. 51: 173-182.

Hata, K., Kato, H. and Kachi, N. 2010 Litter of an alien tree, Casuarina equisetifolia, inhibits seed germination and initial growth of a native tree on the Ogasawara Islands (subtropical oceanic islands). J. For. Res. 15: 384-390.

van Hees, A. 1997 Growth and morphology of pedunculate oak (Quercus robur L) and beech (Fagus sylvatica L) seedlings in relation to shading and drought. Ann. Sci. For. 54: 9-18.

Heilmeier, H., Baronius, K., Kuhn, A.J., Opfermann, M. and Nebe, W. 2000a Wachstum und Ernährung von Eberesche, Buche und Fichte im Gefäßversuch mit immissionsbelasteten Bodensubstraten aus dem Erzgebirge. J. Plant. Nutr. Soil Sci. 163: 57-63. 
Heilmeier, H., Baronius, K., Nebe, W. and Kuhn, A.J. 2000b Wachstum und Ernährung von Birke, Buche, Fichte und Tanne bei unterschiedlichem Stickstoff- und Schwefelangebot im Gefäßversuch. Forstw. Cbl. 119: 161-176.

Hollinger, D.Y. 1987 Gas exchange and dry matter allocation responses to elevation of atmospheric $\mathrm{CO}_{2}$ concentration in seedlings of three tree species. Tree Physiol. 3: 193-202.

Huat, O.K., Awang, K., Hashim, A. and Majid, N.M. 2002 Effects of fertilizers and vesiculararbuscular mycorrhizas on the growth and photosynthesis of Azadirachta excelsa (Jack) Jacobs seedlings. For. Ecol. Manag. 158: 51-58.

Jensen, J.S. and Hansen, J.K. 2010 Genetic variation in responses to different soil water treatments in Quercus robur L. Scand. J. of Forest Res. 25: 400-411.

Jung, P. 2008 Effect of faeces from different lepidopterans, after feeding on pines, on growth in hight and root collar diameter of young pines, birches, and oaks. Allg. Forst Jagdztg. 179: $7-13$.

Kaushal, P., Guehl, J.M. and Aussenac, G. 1989 Differential growth response to atmospheric carbon dioxide enrichment in seedlings of Cedrus atlantica and Pinus nigra ssp. Laricio var. Corsicana. Can. J. For. Res. 19: 1351-1358.

Kawaletz H., Mölder I., Zerbe S., Annighöfer P., Terwei A., Ammer C. (2013): Exotic tree seedlings are much more competitive than natives but show underyielding when growing together. J Plant Ecol 6 (4): 305-315.

Kohout, P., Sykorova, Z., Bahram, M., Hadincová, V., Albrechtová, J., Tedersoo, L. and Vohník, M. 2011 Ericaceous dwarf shrubs affect ectomycorrhizal fungal community of the invasive Pinus strobus and native Pinus sylvestris in a pot experiment. Mycorrbiza 21: 403-412.

Kramer, P. 1936 Effect of variation in length of day on growth and dormancy of trees. Plant Physiol. 11: 127-137.

Kress, L. and Skelly, J. 1982 Response of several eastern forest tree species to chronic doses of ozone and nitrogen dioxide. Plant Dis. 66: 1149-1152.

Li, Q., Liang, Y., Tong, B., Du, X. and Ma, K. 2010 Compensatory effects between Pinus massoniana and broadleaved tree species. J. Plant Ecol. 3: 183-189.

Lippert, M., Häberle, K.-H., Steiner, K., Payer, H.-D. and Rehfuess, K.-E. 1996 Interactive effects of elevated $\mathrm{CO}_{2}$ and $\mathrm{O}_{3}$ on photosynthesis and biomass production of clonal 5-yearold Norway spruce [Picea abies (L.) Karst.] under different nitrogen nutrition and irrigation treatments. Trees 10: 382-392. 
Löf, M. and Welander, N.T. 2000 Carry-over effects on growth and transpiration in Fagus sylvatica seedlings after drought at various stages of development. Can. J. For. Res. 30: 468-475.

Loh, F.C.W., Grabosky, J.C. and Bassuk, N.L. 2003 Growth response of Ficus benjamina to limited soil volume and soil dilution in a skeletal soil container study. Urban For. Urban Greening 2: $53-62$.

Long, T.J. and Jones, R.H. 1996 Seedling growth strategies and seed size effects in fourteen oak species native to different soil moisture habitats. Trees 11:1-8.

Madsen, P. 1994 Growth and survival of Fagus sylvatica seedlings in relation to light intensity and soil water content. Scand. J. of Forest Res. 9: 316-322.

Mangan, S.A., Schnitzer, S.A., Herre, E.A., Mack, K.M.L., Valencia, M.C., Sanchez, E.I. and Bever, J.D. 2010 Negative plant-soil feedback predicts tree-species relative abundance in a tropical forest. Nature 466: 752-755.

McComb, A.L. and Kapel, F.J. 1942 Effect of subsoil acidity and fertility on the growth of seedling black locust and green ash. Plant Physiol. 17: 7-15.

Meier, I.C. 2007: Aboveground and belowground response of European beech to drought: field studies and experiments. Dissertation, University of Göttingen.

Michelsen, A. and Rosendahl, S. 1990 The effect of VA mycorrhizal fungi, phosphorus and drought stress on the growth of Acacia nilotica and Leucaena leucocephala seedlings. Plant and Soil 124: 7-13.

Mielke, M.S. and Schaffer, B. 2010 Leaf gas exchange, chlorophyll fluorescence and pigment indexes of Eugenia uniflora L. in response to changes in light intensity and soil flooding. Tree Physiol. 30: 45-55.

van der Moezel, P.G., Pearce-Pinto, G.V.N. and Bell, D.T. 1991 Screening for salt and waterlogging tolerance in Eucalyptus and Melaleuca species. For. Ecol. Manag. 40: 27-37.

Moore, C. 1959 Interaction of species and soil in relation to the distribution of Eucalypts. Ecology 40: 734-735.

Oberbauer, S., Strain, B. and Fetcher, N. 1985 Effect of $\mathrm{CO}_{2}$ enrichment on seedling physiology and growth of two tropical tree species. Physiol. Plant. 65: 352-356.

Osunkoya, O.O., Othman, F.E. and Kahar, R.S. 2005 Growth and competition between seedlings of an invasive plantation tree, Acacia mangium, and those of a native Borneo heathforest species, Melastoma beccarianum. Ecol. Res. 20: 205-214. 
Otieno, D.O., Schmidt, M.W.T., Adiku, S. and Tenhunen, J. 2005 Physiological and morphological responses to water stress in two Acacia species from contrasting habitats. Tree Physiol. 25: 361-371.

Parelle, J., Brendel, O., Bodénès, C., Berveiller, D., Dizengremel, P., Jolivet, Y. and Dreyer, E. 2006 Differences in morphological and physiological responses to water-logging between two sympatric oak species (Quercus petraea [Matt.] Liebl., Quercus robur L.). Ann. For. Sci. 63: 849-859.

Pashanasi, B., Melendez, G., Szott, L. and Lavelle, P. 1992 Effect of inoculation with the endogeic earthworm Pontoscolex corethrurus (Glossoscolecidae) on N availability, soil microbial biomass and the growth of three tropical fruit tree seedlings in a pot experiment. Soil Biol. Biochem. 24: 1655-1659.

Pfirrmann, T., Barnes, J., Steiner, K., Schramel, P., Busch, U., Küchenhoff, H. and Payer, H.-D. 1996 Effects of elevated $\mathrm{CO}_{2}, \mathrm{O}_{3}$ and $\mathrm{K}$ deficiency on Norway spruce (Picea abies): Nutrient supply, content and leaching. New Phytol. 134: 267-278.

Reubens, B., Pannemans, B., Danjon, F., De Proft, M., De Baets, S., De Baerdemaeker, J., Poesen, F. and Muys, B. 2009 The effect of mechanical stimulation on root and shoot development of young containerised Quercus robur and Robinia psendoacacia trees. Trees Struct. Funct. 23: 1213-1228.

Rogers, W.E. and Siemann, E. 2003 Effects of simulated herbivory and resources on Chinese tallow tree (Sapium sebiferum, Euphorbiaceae) invasion of native coastal prairie. Am. J. Bot. 90: 243-249.

Rogers, W.E. and Siemann, E. 2002 Effects of simulated herbivory and resource availability on native and invasive exotic tree seedlings. Basic and Appl. Ecol. 3: 297-307.

Rose, L., Leuschner, C., Köckemann, B. and Buschmann, H. 2009 Are marginal beech (Fagus sylvatica L.) provenances a source for drought tolerant ecotypes? Eur. J. Forest Res. 128: $335-343$.

Sanginga, N., Gwaze, D. and Swift, M. 1991 Nutrient requirements of exotic tree species in Zimbabwe. Plant Soil 132: 197-205.

Sanon, A., Martin, P., Thioulouse, J., Plenchette, C., Spichiger, R., Lepage, M. and Duponnois, R. 2006 Displacement of an herbaceous plant species community by mycorrhizal and nonmycorrhizal Gmelina arborea, an exotic tree, grown in a microcosm experiment. Mycorrbiza 16: $125-132$. 
Saxe, H. and Kerstiens, G. 2005 Climate change reverses the competitive balance of ash and beech seedlings under simulated forest conditions. Plant Biology 7: 375-386.

Schall, P., Lödige, C., Beck, M. and Ammer, C. 2012 Biomass allocation to roots and shoots is more sensitive to shade and drought in European beech than in Norway spruce seedlings. For. Ecol. Manag. 266: 246-253.

Schumacher, E., Kueffer, C., Tobler, M., Gmür, V., Edwards, P.J. and Dietz, H. 2008 Influence of drought and shade on seedling growth of native and invasive trees in the Seychelles. Biotropica 40: 543-549.

Schumacher, E.M. 2007 Variation in growth responses among and within native and invasive juvenile trees in Seychelles. Dissertation, ETH Zürich.

Sell, J., Kayser, A., Schulin, R. and Brunner, I. 2005 Contribution of ectomycorrhizal fungi to cadmium uptake of poplars and willows from a heavily polluted soil. Plant and Soil 277: $245-253$.

e Silva, F.C., Shvaleva, A., Maroco, J.P., Almeida, M.H., Chaves, M.M. and Pereira, J.S. (2004): Responses to water stress in two Eucalyptus globulus clones differing in drought tolerance. Tree Physiol 24: 1165-1172.

Silvola, J. and Ahlholm, U. 1992 Photosynthesis in willows (Salix $x$ dasyclados) grown at different $\mathrm{CO}_{2}$ concentrations and fertilization levels. Oecologia 91: 208-213.

Takahashi, K. 1998 Oxygen isotope ratios between soil water and stem water of trees in pot experiments. Ecol. Res. 13: 1-5.

Tanner, E.V.J., Teo, V.K., Coomes, D.A. and Midgley, J.J. 2005 Pair-wise competition-trials amongst seedlings of ten dipterocarp species; the role of initial height, growth rate and leaf attributes. J. Trop. Ecol. 21: 317-328.

Tognetti, R., Johnson, J. and Michelozzi, M. 1997 Ecophysiological responses of Fagus sylvatica seedlings to changing light conditions. I. Interactions between photosynthetic acclimation and photoinhibition during simulated canopy gap formation. Physiol. Plant. 101: 115-123.

Tognetti, R., Michelozzi, M. and Borghetti, M. 1994 Response to light of shade-grown beech seedlings subjected to different watering regimes. Tree Physiol. 14: 751-758.

Tognetti, R., Minotta, G., Pinzauti, S., Michelozzi, M. and Borghetti, M. 1998 Acclimation to changing light conditions of long-term shade-grown beech (Fagus sylvatica L.) seedlings of different geographic origins. Trees 12: 326-333. 
Toledo-Aceves, T. and Swaine, M.D. 2007 Above- and below-ground competition between the liana Acacia kamerunensis and tree seedlings in contrasting light environments. Plant Ecol. 196: 233-244.

Valladares, F., Chico, J., Aranda, I., Balaguer, L., Dizengremel, P., Manrique, E. and Dreyer, E. 2002 The greater seedling high-light tolerance of Quercus robur over Fagus sylvatica is linked to a greater physiological plasticity. Trees - Struct. Funct. 16: 395-403.

Vivin, P., Aussenac, G. and Levy, G. 1993 Differences in drought resistance among 3 deciduous oak species grown in large boxes. Ann. Sci. For. 50: 221-233.

Wagner, P. and Dreyer, E. 1997 Interactive effects of waterlogging and irradiance on the photosynthetic performance of seedlings from three oak species displaying different sensitivities (Quercus robur, Q. petraea and Q. rubra). Ann. Sci. For. 54: 409-429.

Weber-Blaschke, G., Claus, M. and Rehfuess, K.E. 2002 Growth and nutrition of ash (Fraxinus excelsior L.) and sycamore (Acer pseudoplatanus L.) on soils of different base saturation in pot experiments. For. Ecol. Manag. 167: 43-56.

Weber-Blaschke, G. and Rehfuess, K.E. 2002 Correction of Al toxicity with European ash (Fraxinus excelsior L.) growing on acid soils by fertilization with $\mathrm{Ca}$ and $\mathrm{Mg}$ carbonate and sulfate in pot experiments. For. Ecol. Manag. 167: 173-183.

Weih, M. and Nordh, N. 2005 Determinants of biomass production in hybrid willows and prediction of field performance from pot studies. Tree Physiol. 25: 1197-1206.

Weih, M. and Nordh, N. 2002 Characterising willows for biomass and phytoremediation: growth, nitrogen and water use of 14 willow clones under different irrigation and fertilisation regimes. Biomass Bioenergy 23: 397-413.

Willoughby, I., Dixon, F.L., Clay, D.V. and Jinks, R.L. 2007 Tolerance of broadleaved tree and shrub seedlings to preemergence herbicides. New For. 34: 1-12.

Wölfle, C., Häberle, K.-H., Kölling, C. and Rehfuess, K.E. 2000 Über den Einfluß von wiederholter Ammoniumnitrat-Düngung auf Substrat, Ernährungszustand und Wachstum junger Fichten (Picea abies [L.] Karst.) in den Hochlagen des Bayerischen Waldes Ergebnisse eines Container-Experiments. Forstw. Cbl. 119: 114-127.

Yan, M.-J., Yamanaka, N., Yamamoto, F. and Du, S. 2010 Responses of leaf gas exchange, water relations, and water consumption in seedlings of four semiarid tree species to soil drying. Acta Physiol. Plant. 32: 183-189. 
Young, C.-C. 1990 Effects of phosphorus-solubilizing bacteria and vesicular-arbuscular mycorrhizal fungi on the growth of tree species in subtropical-tropical soils. Soil Sc. Plant Nutr. 36: 225-231.

Železnik, P., Hrenko, M., Then, C., Koch, N., Grebenc, T., Levanič, T. and Kraigher, H. 2007 CASIROZ: Root parameters and types of ectomycorrhiza of young beech plants exposed to different ozone and light regimes. Plant Biol. 9: 298-308.

Zeugin, F. 2010 The functional significance of tree diversity for nutrient acquisition in a tropical tree plantation. Dissertation, ETH Zürich.

Zhang, Y., Ma, X. and Zhou, Z. 2012 The influence of light conditions and interspecific competition on the root foraging traits and seedling growth of two tree species. Plant Biosyst. 146: 7-14.

Zhang, Y., Zhou, Z., Ma, X. and Jin, G. 2010 Foraging ability and growth performance of four subtropical tree species in response to heterogeneous nutrient environments. J. For. Res. 15: $91-98$.

Zou, J., Rogers, W.E., DeWalt, S.J. and Siemann, E. 2006 The effect of Chinese tallow tree (Sapium sebiferum) ecotype on soil-plant system carbon and nitrogen processes. Oecologia 150: 272-281.

Zou, J., Rogers, W.E. and Siemann, E. 2008 Increased competitive ability and herbivory tolerance in the invasive plant Sapium sebiferum. Biol. Invasions 10: 291-302. 
Chapter 3
Exotic tree seedlings are much more competitive than natives but show underyielding when growing together

H. Kawaletz, I. Mölder, S. Zerbe, P. Annighöfer, A. Terwei, C. Ammer Journal of Plant Ecology (2013), 6 (4): 305-315 
Journal of

Plant Ecology

VOLUME 6, NUMBER 4, PAGES 305-315

AUGUST 2013

doi:10.1093/jpe/rts044

Advance Access publication

23 January 2013

available online at

www.jpe.oxfordjournals.org

\section{Exotic tree seedlings are much more competitive than natives but show underyielding when growing together}

\author{
Heike Kawaletz ${ }^{1, *}$, Inga Mölder ${ }^{2}$, Stefan Zerbe ${ }^{3}$, Peter Annighöfer ${ }^{1}$, \\ André Terwei ${ }^{3}$ and Christian Ammer ${ }^{I}$ \\ 1 Department of Silviculture and Forest Ecology of the Temperate Zones, University of Göttingen, Büsgenweg 1, 37077 \\ Göttingen, Germany \\ ${ }^{2}$ Energieagentur Region Göttingen e.V., Berliner Str. 2, 37073 Göttingen, Germany \\ ${ }^{3}$ Faculty of Science and Technology, Free University of Bozen-Bolzano, Piazza Università S, 39100 Bolzano, Italy \\ *Correspondence address. Department of Silviculture and Forest Ecology of the Temperate Zones, University \\ of Göttingen, Büsgenweg 1, 37077 Göttingen, Germany. Tel: +49-551-393673; Fax: +49-551-393270; E-mail: \\ hkawale@gwdg.de
}

\section{Abstract}

\section{Aims}

Invasive species continue to be a worldwide threat to ecosystems mainly as a cause for biodiversity loss. Forest ecosystems, for example, are subject to a change in species composition due to the invasion of exotic species. Specifying the attributes that cause the strong competitiveness of several exotic species may improve the ability to understand and effectively manage plant invasions in the future. In this study the following hypotheses were tested: (1) biomass production of below- and aboveground plant components of the exotic tree species is higher than that of the natives, resulting in a higher competitiveness of the exotics; (2) the exclusion of root competition has a positive effect on the biomass production of the inferior native species; and (3) mixtures of native and exotic species yield a higher biomass production than the respective monocultures.

\section{Methods}

A pot experiment, containing about 2000 tree seedlings, was established. We investigated the biomass productivity and growth reactions of two native (Quercus robur L., Carpinus betulus L.) and two exotic tree species (Prunus serotina Ehrh., Robinia pseudoacacia L.) in different intra- and interspecific, competitive situations with and without the influence of root competition.

\section{Important Findings}

The biomass production of both exotic species was significantly higher and led to a strong competitive advantage, resulting in a biomass decrease of the less competitive native species. The high belowground biomass of both exotic species had a negative effect on the biomass production. The competitive pressure of exotic tree seedlings on the native ones was largely driven by root competition. Furthermore, mixtures of native and exotic tree species had a higher productivity than their growth in monocultures would have predicted. Competition was lower for exotic species in mixtures with the less productive native species compared to the competition in monocultures or in mixture with the other highly productive exotic species. Accordingly, both highly competitive exotic species produced less biomass in mixture with each other compared to monocultures. Despite the significantly higher biomass of $P$. serotina in all mixtures and in monoculture, $R$. pseudoacacia seemed to be the dominating species. Due to its strong root competition, $R$. pseudoacacia significantly reduced the biomass production of $P$. serotina.

Keywords: competition - biomass production - pot experiment $\bullet$ invasive species $\bullet$ Prunus serotina $\bullet$ Robinia pseudoacacia

Received: 16 July 2012 Revised: 26 November 2012 Accepted: 5 December 2012

\section{INTRODUCTION}

The invasion of exotic species is regarded as one of the main reasons for changing natural plant communities and biodiversity loss worldwide. By means of human influence, a lot of invasive exotic species have successfully established in several regions across Europe in the last century (Kowarik 2010). The highly competitive invaders are not necessarily 
also the dominant species in their native range (Callaway and Aschehoug 2000). Once established, however, invasive species can cause silvicultural management problems by displacing native species and possibly altering ecosystem functions (Ammer et al. 2011). Distinguishing the specific traits causing their high competitiveness compared to native species could improve the ability to effectively manage plant invasions in the future. But the traits causing the observed predominance of invasive species on co-occurring native species are often still unknown. There are a lot of studies trying to identify the attributes that enable a species to invade a new habitat (e.g. Alpert et al. 2000; Bray et al. 2003; Callaway and Aschehoug 2000; Closset-Kopp et al. 2007; Williamson and Fitter 1996). In addition to various dispersal-based characteristics (Rejmanek and Richardson 1996), other morphological attributes like biomass production, growth rate and leaf area may also play an important role for tree invasions (Lamarque et al. 2011; Pyšek and Richardson 2008; Williamson and Fitter 1996). One advantage for the success of invasive exotic species in new ecosystems may be a better response to unused resources (e.g. light, nutrients) followed by a higher biomass productivity compared to native species. Gurevitch et al. (2008) supported this assumption by studying relative growth rates of different exotic woody species, which showed highest relative growth rates in gaps with good light conditions and on fertile soils. Accordingly, Morrison and Mauck (2007) found for Acer platanoides L., an important invasive tree species in North America, that its seedlings produce more leaves and have a higher root biomass compared to the native maple Acer saccharum Marsh., and assumed this to be an explanation for the success of A. platanoides.

To describe the effects of competition between native and exotic species more precisely, interactions between plants should be studied by distinguishing between belowground and aboveground competition. Root competition is an important and sometimes dominant factor in plant communities (Casper and Jackson 1997; Schenk 2006; Wilson 1988) and involves more neighbors and resources (water, several essential mineral nutrients) than does aboveground competition, which is mainly based on light availability (Casper and Jackson 1997). The intensity of root competition imposed by the dominant species is one factor determining the growth and survival of adjacent trees (Coomes and Grubb 1998). However, only few studies investigated the importance and intensity of root competition between different tree species in forests stands (Bi et al. 1992; Casper and Jackson 1997; Fredericksen and Zedaker 1995; Leuschner et al. 2001; Meinen et al. 2009). For instance, Leuschner et al. (2001) found that the highly competitive beech (Fagus sylvatica L.) suppresses the growth and vitality of admixed oaks (Quercus robur $\mathrm{L}$.) belowground. The strong competitiveness of beech trees in mixtures resulted in a remarkable decrease of the oak's fine-root biomass. In the study presented here, we hypothesized that the exotic species have similar negative effects on the growth of the native species.
Apart from individual plant growth, interactions in species mixtures, based on competition and facilitation, have an important influence on the individual plant survival and growth. Niche partitioning allows species to share the same resources and to coexist. Positive interactions between species can result in an increasing biomass production of one of the species or of the species collective as a whole. Possible explanations for this higher biomass production are a reduction of competition in species mixtures compared to monocultures due to complementarity effects, on the one hand, and facilitation, i.e. one species has a beneficial effect on the growth of another species, on the other (Kelty 1992; Pretzsch and Schütze 2009). While aboveground productivity of grasslands usually increases with increasing species diversity (e.g. Dybzinski et al. 2008; Hector et al. 1999; Tilman et al. 1996), studies regarding the influence of tree species diversity on the productivity of forests show inconsistent results. Some tree species mixtures yielded a higher biomass production than did monocultures (Bauhus et al. 2000; Brown 1992; Erskine et al. 2006; Pretzsch et al. 2010; Vilà et al. 2007), whereas others result in similar (Vilà et al. 2003) or even lower biomass production (Jacob et al. 2010; Szwagrzyk and Gazda 2007). As Pretzsch et al. (2010) showed, site productivity does strongly influence the diversity-productivity relationship. So far, the question whether mixing tree species increases productivity (Cardinale et al. 2007; Hector 2006; Pretzsch and Schütze 2009 ) in managed forests or in biodiversity experiments has not been conclusively answered. However, focusing on mixtures between native and exotic species may help to disentangle the complex interactions between tree species. Thus, the traits leading to over- or underyielding might be more striking in such mixtures than in mixtures having a long history of coevolution.

The aim of our study was to evaluate the predominance of the two North American species, black cherry (Prunus serotina Ehrh.) and black locust (Robinia pseudoacacia L.), which have effectively invaded many European forest ecosystems (e.g. Annighöfer et al. 2012; Closset-Kopp et al. 2011; Kleinbauer et al. 2010; Motta et al. 2009; Starfinger et al. 2003). The study site of our research group, the biosphere reserve 'Valle del Ticino' in Northwestern Italy, represents such an area that is affected by these species. Since the two exotic tree species were introduced to the area during the end of the 19th century, their abundance has strongly increased, so that the integrity of the forest ecosystem is endangered at present (Annighöfer et al. 2012). In Europe, P. serotina and R. pseudoacacia are invasive exotic species (Kowarik 2010) that have established and are regarded as strong competitors of native tree species (e.g. Closset-Kopp et al. 2011; González-Muñoz et al. 2011; Kleinbauer et al. 2010; Vanhellemont et al. 2010). Both species were introduced to Europe for various reasons, e.g. timber production, soil improvement and fire prevention (Godefroid et al. 2005; Knight et al. 2008; Motta et al. 2009). Due to its great competitiveness, P. serotina displaces local species and thus is considered to be invasive (Closset-Kopp et al. 2007); 
it is even referred to as an 'aggressively spreading species' (Knight et al. 2008; Starfinger et al. 2003). As a nitrogenfixing species, $R$. pseudoacacia changes soil conditions and species compositions on many sites (Motta et al. 2009; Rice et al. 2004).

In our study, the growth reactions of two native (Quercus robur L. and Carpinus betulus L.) and two exotic (P. serotina and R. pseudoacacia) tree species in different inter- and intraspecific competitive situations were investigated under the controlled conditions of a pot experiment. The different tree species were arranged in monocultures and two-species mixtures. The following hypotheses were tested: (1) biomass production of below- and aboveground plant components of the exotic tree species is higher than that of the natives, resulting in a higher competitiveness of the exotics; (2) the exclusion of root competition has a positive effect on the biomass production of the inferior species; and (3) mixtures of native and exotic species yield a higher biomass production than the respective monocultures.

\section{METHODS}

\section{Experimental set-up}

The pot experiment was conducted under outdoor conditions in Göttingen, Germany. The experimental site was located at $170 \mathrm{~m}$ above sea level. The climate is temperate with an average annual precipitation of $644.9 \mathrm{~mm}$ and most of the rain falling in June $(81.3 \mathrm{~mm})$. The temperature ranges from 4.8 to $13^{\circ} \mathrm{C}$ with a mean annual temperature of about $8.7^{\circ} \mathrm{C}$. To ensure comparability with the vegetation of the biosphere reserve 'Valle del Ticino', tree species were used that are typi$\mathrm{cal}$ for the vegetation found in the reserve: pedunculate oak (Q. robur) and hornbeam (C. betulus) as native species, black cherry (P. serotina) and black locust (R. pseudoacacia) as exotic species. In order to use already established plants and to minimize transport-induced damages, all trees were about 1 year old and originated from a nursery in Germany (Münchehof, Lower Saxony), where all plants had grown under homogenous conditions. In spring 2010, the seedlings were planted into pots (volume $65 \mathrm{l}$, diameter $54 \mathrm{~cm}$, height $33 \mathrm{~cm}$ ). The pots were filled with fertilized potting soil (Einheitserdeund Humuswerke, Gebr. Patzer GmbH \& Co. KG, SinntalJossa/Germany, type Eurohum CRH) above a 5-cm layer of coarse gravel to improve drainage. We used potting soil to ensure homogeneous substrate and nutrient conditions in all pots. The tree seedlings were watered as needed with all pots receiving the same amount of water. Excess water was drained through holes in the bottom of the pots. During winter, the pots were arranged close to each other and embedded in foliar litter to prevent frost damage to the roots. All pots were placed randomly on the area to avoid edge effects. The plants were examined during two growing periods lasting from April 2010 to October 2011.

Four seedlings were planted per pot and arranged in 10 different species mixtures, of which 4 were monocultures and 6 were species mixtures. The species mixtures consisted of not more than two species and were: (1) Q. robur with C. betulus, (2) R. pseudoacacia with P. serotina, (3) Q. robur with R. pseudoacacia, (4) Q. robur with P. serotina, (5) C. betulus with $R$. pseudoacacia and (6) C. betulus with P. serotina. There were 36 replicates for the monoculture pots and 60 replicates for each of the six species mixtures. Pots with dead seedlings were excluded from further analyses, since even one dead plant per pot would have changed the competitive situation compared to those pots containing four plants. This reduced the number of pots from 504 to 201 (Table 1).

In the study area, $P$. serotina and various shrubs create quite shady conditions in the understorey. Thus, Q. robur and C. betulus seedlings can hardly be found, even under a loose canopy of mature oak trees in the overstorey. Since $Q$. robur is a shade-intolerant species and we did not want to reduce its competiveness by shade, the study was carried out under full light. Nevertheless, the growing conditions for all individuals and all species were similar.

\section{Competition treatments}

To study the competitive mechanisms in more detail, root and shoot competition were investigated using a modified 'divided pot technique' (Donald 1958; McPhee and Aarssen

Table 1: amount of pots per mixture type and treatment at the beginning (intended) and at the end (effective) of the pot experiment. The treatments were RC and nRC. Mortality reduced the amount of replicates. All pots contained four plants

\begin{tabular}{|c|c|c|c|}
\hline \multirow[b]{2}{*}{ Species composition } & \multirow[b]{2}{*}{ Treatments } & \multicolumn{2}{|c|}{ Replicates } \\
\hline & & Intended & Effective \\
\hline \multirow[t]{2}{*}{ Monoculture Q. robur } & RC & 24 & 18 \\
\hline & $\mathrm{nRC}$ & 12 & 6 \\
\hline \multirow[t]{2}{*}{ Monoculture $C$. betulus } & $\mathrm{RC}$ & 24 & 15 \\
\hline & $\mathrm{nRC}$ & 12 & 8 \\
\hline \multirow[t]{2}{*}{ Monoculture $R$. pseudoacacia } & RC & 24 & 11 \\
\hline & $\mathrm{nRC}$ & 12 & 7 \\
\hline \multirow[t]{2}{*}{ Monoculture P. serotina } & $\mathrm{RC}$ & 24 & 5 \\
\hline & $\mathrm{nRC}$ & 12 & 6 \\
\hline \multirow[t]{2}{*}{ Mixture of $Q$. robur with C. betulus } & $\mathrm{RC}$ & 40 & 20 \\
\hline & $\mathrm{nRC}$ & 20 & 16 \\
\hline \multirow{2}{*}{$\begin{array}{l}\text { Mixture of } R \text {. pseudoacacia with } \\
\text { P. serotina }\end{array}$} & $\mathrm{RC}$ & 40 & 8 \\
\hline & $\mathrm{nRC}$ & 20 & 4 \\
\hline \multirow{2}{*}{$\begin{array}{l}\text { Mixture of Q. robur with } \\
\text { R. pseudoacacia }\end{array}$} & $\mathrm{RC}$ & 40 & 14 \\
\hline & $\mathrm{nRC}$ & 20 & 9 \\
\hline \multirow[t]{2}{*}{ Mixture of Q. robur with P. serotina } & $\mathrm{RC}$ & 40 & 11 \\
\hline & $\mathrm{nRC}$ & 20 & 5 \\
\hline \multirow{2}{*}{$\begin{array}{l}\text { Mixture of C. betulus with } \\
\text { R. pseudoacacia }\end{array}$} & $\mathrm{RC}$ & 40 & 16 \\
\hline & $\mathrm{nRC}$ & 20 & 7 \\
\hline \multirow[t]{2}{*}{ Mixture of $C$. betulus with $P$. serotina } & $\mathrm{RC}$ & 40 & 12 \\
\hline & $\mathrm{nRC}$ & 20 & 3 \\
\hline Amount of pots & & 504 & 201 \\
\hline
\end{tabular}


2001; Snaydon 1971). All tree seedlings were distributed to root, shoot and full competition treatments. We installed aboveground partitions allowing only root competition, and belowground partitions allowing only shoot competition. The above- and belowground partitions were made of white rigid PVC sheets. White aboveground partitions reflected the sunlight and thus leveled the light conditions on all four sections of the pot. In our experiment, shoot competition had no significant effect on tree growth (data not shown). However, if the two treatments in which the seedlings were exposed to root competition (i.e. root and full competition) were pooled and compared with the treatment excluding root competition (i.e. shoot competition), for $C$. betulus $(P=0.03)$ and $P$. serotina $(P=0.02)$ an effect of root competition was found (Table 3). In the following, we therefore contrast 'root competition' (RC) with 'no root competition' (nRC). The number of pots per mixture type and treatment is shown in Table 1.

\section{Measurements}

To assess the initial dry weight of each species, a random sample of 10 plants per species was collected at the beginning of the experiment. To assess the dry weight at the end of the experiment, all pots with four living plants were harvested resulting in a total of $n=804$ trees, of which $n=246$ were Q. robur, $n=240$ were $C$. betulus, $n=188$ were $R$. pseudoacacia, and $n=130$ were $P$. serotina seedlings. The biomass of every tree seedling, both at the beginning and at the end of the study, was assigned to one of the four tree components: main shoot, branches, roots or leaves. The dry weight of all four biomass categories was determined separately by drying for 3 days at $70^{\circ} \mathrm{C}$ in a temperature-controlled oven until a constant weight was achieved. The tree components were then weighed with an accuracy of $0.001 \mathrm{~g}$.

\section{Data analysis}

In order to facilitate the comparison of our findings with other studies on biomass productivity in monocultures and species mixtures, we were interested whether or not pattern of overand/or underyielding might be observed when analysing the different mixtures. A mixture is showing 'overyielding' if the yield of the mixture is greater than expected based on a weighted average of the monoculture yields of the component species, i.e. $p_{1,2}>\left(m_{1} \cdot p_{1}+m_{2} \cdot p_{2}\right)$ (see Pretzsch 2005). In our experiment, only balanced two-species mixtures were used, i.e. every species in a mixture had a proportion of $50 \%$. Thus, no weighing of species share was necessary. According to the definition of overyielding, 'underyielding' indicates a negative interaction. Over- and underyielding were calculated by

$$
\Delta p_{\text {rel }}=\left[p_{1,2} /\left(\mathrm{m}_{1} \cdot p_{1}+\mathrm{m}_{2} \cdot p_{2}\right)-1\right] \cdot 100,
$$

where $p_{1,2}$ is the dry mass of the mixture, $p_{1}$ and $p_{2}$ are the dry biomass productivities of species 1 and 2 in monocultures, and $m_{1}$ and $m_{2}$ are the proportions of species 1 and 2 in the mixture.
The so-called transgressive overyielding of the mixture occurs if biomass productivity of a mixture outperforms even the yield of the most productive monoculture of the species involved. Thus, transgressive overyielding is characterized by $p_{1,2}>\max \left(p_{1}, p_{2}\right)$ (see Pretzsch 2005). Accordingly, transgressive overyielding was calculated as

$$
\Delta p_{\text {abs }}=\left[p_{1,2} / \max \left(p_{1}, p_{2}\right)-1\right] \cdot 100
$$

and transgressive underyielding was calculated as

$$
\Delta \mathrm{pabs}=\left[p_{1,2} / \min \left(p_{1}, p_{2}\right)-1\right] \cdot 100 .
$$

All statistical tests and graphs were conducted using the free software environment R (R Development Core Team 2012). The Shapiro-Wilk normality test was used to analyse data distribution. To assess homoscedasticity, we used Levene's test. If data showed a normal distribution and if the variances were homogenous, we used an analysis of variance (ANOVA) and Tukey range test to find significant differences between groups. If data could not be assumed to be normally distributed and/or did not show homoscedasticity, we used the Kruskal-Wallis test and applied pairwise comparisons with Wilcoxon rank sum test. All tests comparing groups were two-sided.

\section{RESULTS}

\section{Biomass and allocation}

The woody biomasses per plant at the beginning of the pot experiment differed considerably between the four species (Table 2) even though the individuals of all species were of the same age ( 1 year old). Total biomass (i.e. root, shoot and branch biomass) of $Q$. robur was highest, followed by $R$. pseudoacacia. Both species had significantly higher initial biomasses than had C. betulus and P. serotina. Initial belowground biomass of Q. robur was also significantly higher $(8.41 \mathrm{~g})$ than that for all other species. In contrast, C. betulus had the lowest aboveground, belowground and total biomass.

Woody biomass per plant in monocultures at the end of the pot experiment was significantly lower for both native species, Q. robur and C. betulus, compared to the exotic species,

Table 2: mean total, aboveground (shoot and branches) and belowground (root) biomass at the beginning of the pot experiment (spring 2010). Different characters indicate significant differences between the species $(P<0.05$, Wilcoxon rank sum test, two-sided)

\begin{tabular}{lccll}
\hline Species & $n$ & $\begin{array}{l}\text { Total } \\
\text { biomass }(\mathrm{g})\end{array}$ & $\begin{array}{l}\text { Aboveg round } \\
\text { biomass }(\mathrm{g})\end{array}$ & $\begin{array}{l}\text { Below ground } \\
\text { biomass }(\mathrm{g})\end{array}$ \\
\hline Q. robur & 10 & $14.17^{\mathrm{a}}$ & $5.76^{\mathrm{a}}$ & $8.41^{\mathrm{a}}$ \\
C. betulus & 10 & $6.82^{\mathrm{b}}$ & $2.47^{\mathrm{b}}$ & $4.36^{\mathrm{bc}}$ \\
$\begin{array}{l}\text { R. pseudoacacia } \\
\text { P. serotina }\end{array}$ & 10 & $11.63^{\mathrm{a}}$ & $6.67^{\mathrm{a}}$ & $4.96^{\mathrm{b}}$ \\
& 10 & $7.70^{\mathrm{b}}$ & $3.55^{\mathrm{c}}$ & $4.14^{\mathrm{c}}$ \\
\hline
\end{tabular}



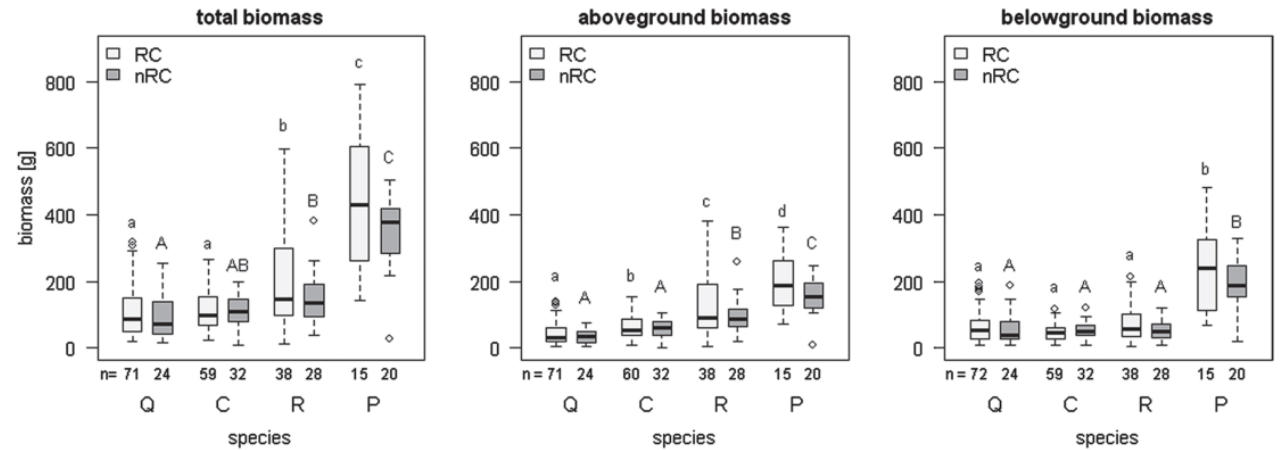

Figure 1: boxplots of total, aboveground (shoot and branches) and belowground (roots) biomass per single plant. Biomasses are given for the end of the pot experiment (autumn 2011) in RC and nRC monocultures. Horizontal lines in each box represent medians. Different characters above each box indicate significant differences between the species in RC (small characters) and nRC (capital characters) $(P<0.05$, ANOVA and Tukey test). $\mathrm{Q}=\mathrm{Q}$. robur, $\mathrm{C}=$ C. betulus, $\mathrm{R}=\mathrm{R}$. pseudoacacia, $\mathrm{P}=$ P. serotina .

P. serotina and R. pseudoacacia (Fig. 1). The initial biomass of P. serotina was very low (Table 2). Nevertheless, this species produced a total biomass that was 3.5 times higher than that of Q. robur and C. betulus. Even compared to R. pseudoacacia, the total biomass of $P$. serotina was more than twice as high. In comparison with all other species, P. serotina showed a significantly higher belowground biomass $(213.03 \mathrm{~g})$. The belowground biomasses of Q. robur, C. betulus and R. pseudoacacia $(62.64,49.70$ and $67.46 \mathrm{~g}$, respectively) did not differ significantly (Fig. 1). In contrast, significant differences between all species growing in monoculture were found for their aboveground biomasses (Fig. 1). Overall, the biomasses of the exotic species were much higher than those of the native species. No significant differences between RC and $\mathrm{nRC}$ were found in the monocultures.

Biomass production per plant was different for all species depending on whether they grew in monocultures or in different species mixtures (Table 3, Fig. 2). While Q. robur yielded the same plant biomass regardless of growing in monoculture or in mixture with $C$. betulus, biomass production of $C$. betulus increased in mixture with Q. robur in both competition treatments (Fig. 2). The exotic species had a strongly negative effect on the mean plant biomass production of both native species (Table 3, Fig. 2). The biomass of the two native species was up to 4.5 times lower in mixtures with P. serotina or R. pseudoacacia than in monocultures (Table 3, Fig. 2). In mixture with R. pseudoacacia, Q. robur showed a slightly higher total biomass in the nRC treatment (36.98g and 26.03g in RC, respectively, $p=0.10$, ANOVA). This effect was even more apparent in mixtures of $C$. betulus with one of the exotic species. In the $\mathrm{nRC}$ treatment, the biomass of $C$. betulus mixed with $R$. pseudoacacia or with P. serotina was higher than in the RC treatment $(42.86 \mathrm{~g}$ and $24.5 \mathrm{lg}$ in mixture with $R$. pseudoacacia, $P=0.04$, Kruskal-Wallis test; $77.46 \mathrm{~g}$ and $26.84 \mathrm{~g}$ in mixture with $P$. serotina, $P=0.02$, Kruskal-Wallis test). Consequently, the proportion of $C$. betulus on total pot biomass differed between $\mathrm{RC}$ and $\mathrm{nRC}$ ( $7 \%$ and $13 \%$ if mixed with R. pseudoacacia; $5 \%$ and $19 \%$ if mixed with P. serotina; $P=0.04$ and $P<0.001$, Table 3 ).
Table 3: percentage of total pot biomass for monocultures and species mixtures distinguished between RC and nRC. Different characters indicate significant differences between the two treatments $(P<0.05$, ANOVA and Kruskal-Wallis test $)$. Mean plant biomass and significant differences between the species mixtures are shown in Fig. 2.

\begin{tabular}{|c|c|c|c|c|c|c|}
\hline \multirow[b]{2}{*}{ Species } & & & \multicolumn{4}{|c|}{ Mixed with } \\
\hline & & & Q. robur & C. betulus & $\begin{array}{l}\text { R. pseudoa- } \\
\text { cacia }\end{array}$ & P. serotina \\
\hline \multirow[t]{2}{*}{ Q. robur } & \multirow{2}{*}{$\begin{array}{l}\% \text { of pot } \\
\text { biomass }\end{array}$} & $\mathrm{RC}$ & - & 41 & 8 & 4 \\
\hline & & $\mathrm{nRC}$ & - & 36 & 11 & 4 \\
\hline \multirow[t]{2}{*}{ C. betulus } & \multirow{2}{*}{$\begin{array}{l}\% \text { of pot } \\
\text { biomass }\end{array}$} & $\mathrm{RC}$ & 59 & - & $7^{\mathrm{a}}$ & $5^{a}$ \\
\hline & & $\mathrm{nRC}$ & 64 & - & $13^{\mathrm{b}}$ & $19^{\mathrm{b}}$ \\
\hline \multirow{2}{*}{$\begin{array}{l}\text { R. pseudoa- } \\
\text { cacia }\end{array}$} & \multirow{2}{*}{$\begin{array}{l}\% \text { of pot } \\
\text { biomass }\end{array}$} & $\mathrm{RC}$ & 92 & $93^{\mathrm{a}}$ & - & 46 \\
\hline & & $\mathrm{nRC}$ & 89 & $87^{b}$ & - & 38 \\
\hline \multirow[t]{2}{*}{ P. serotina } & \multirow{2}{*}{$\begin{array}{l}\% \text { of pot } \\
\text { biomass }\end{array}$} & $\mathrm{RC}$ & 96 & $95^{\mathrm{a}}$ & 54 & - \\
\hline & & $\mathrm{nRC}$ & 96 & $81^{\mathrm{b}}$ & 62 & - \\
\hline
\end{tabular}

While the mean plant biomass of the two exotic species increased if mixed with Q. robur or C. betulus (see above), only R. pseudoacacia was able to yield the same biomass if the two exotic species were mixed (Table 3 ). Overall, the mean plant biomass of $R$. pseudoacacia was higher in all mixtures if root competition was not excluded (Table 3 ). The same is true for P. serotina, except if mixed with R. pseudoacacia. Mean plant biomass of $P$. serotina was significantly lower in mixture with $R$. pseudoacacia than in monoculture, in nRC $(P=0.02$, ANOVA) but even more in RC ( $P<0.001$, ANOVA) (Fig. 2$)$. The biomass proportion per pot of $P$. serotina decreased from $62 \%$ in $\mathrm{RC}$ to $54 \%$ in $\mathrm{nRC}$. Thus, even though P. serotina in mixture with $R$. pseudoacacia contributed more to the total pot biomass (see Fig. 4), the mean plant biomass was much lower than in monoculture or in mixtures with the two native species. 

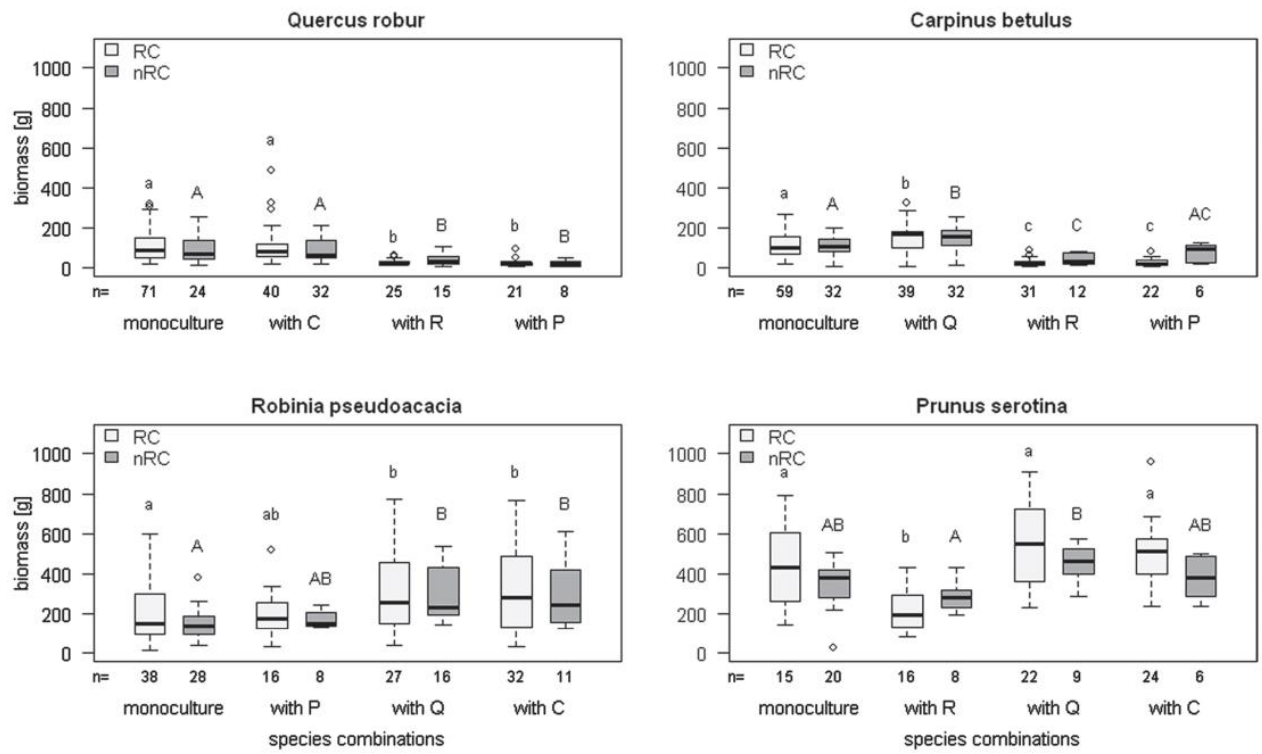

Figure 2: boxplots of mean biomass per plant for the different mixtures with (RC) and without (nRC) root competition. Horizontal lines in each box represent medians. Different characters over each box indicate significant differences between the species mixtures in RC (small characters) and $\mathrm{nRC}$ (capital characters) treatment $(P<0.05$, ANOVA and Tukey test $) . \mathrm{Q}=Q$. robur, $\mathrm{C}=C$. betulus, $\mathrm{R}=R$. pseudoacacia, $\mathrm{P}=P$. serotina .
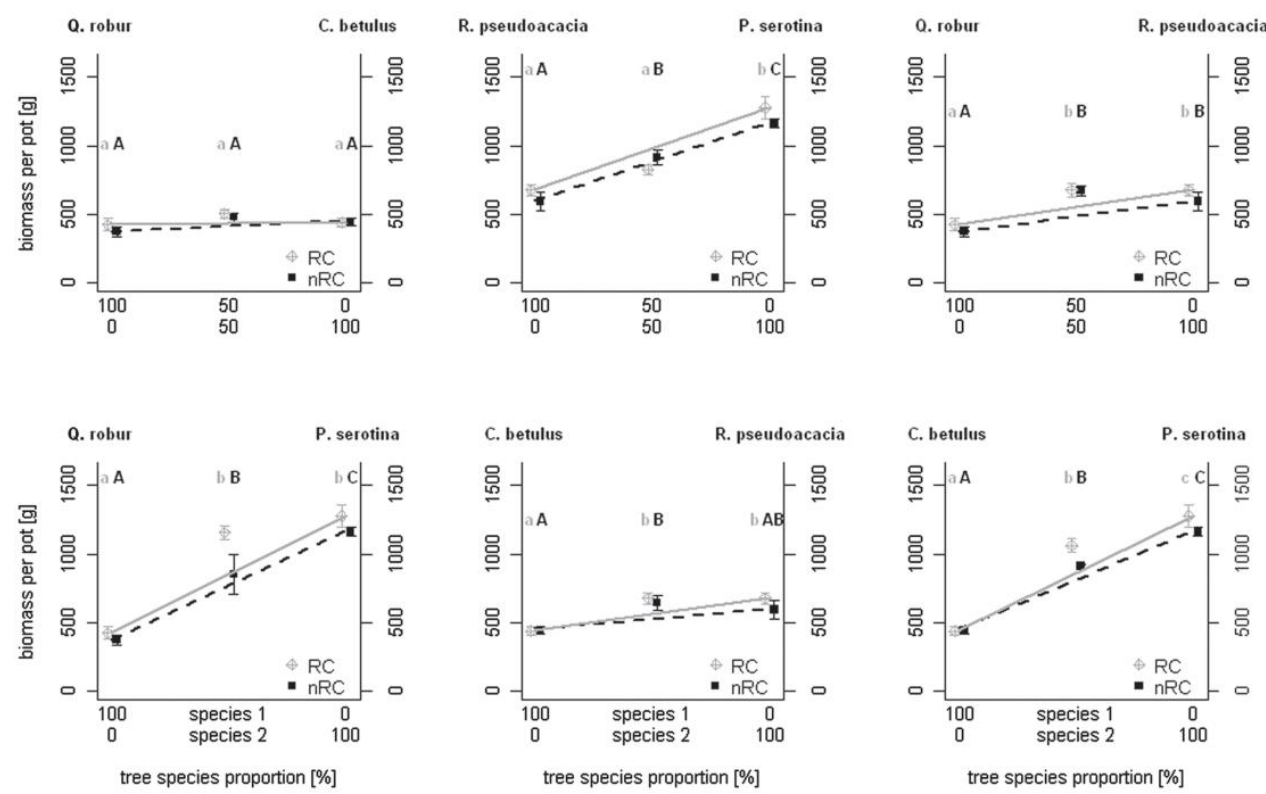

Figure 3: mean total biomass production per pot in monocultures and mixtures with (RC) and without (nRC) root competition. Dots show mean values \pm SE. Dots on the left and right y-axes show the biomass production of two different species in monoculture. The dashed lines show the expected biomass productivity in mixture with neutral interactions between the two species $\left(P_{\text {exp }}\right)$. Different characters above each boxplot indicate significant differences between the species monocultures or mixtures in RC (small characters) and nRC (capital characters) treatment $(P<0.05$, ANOVA $)$ 

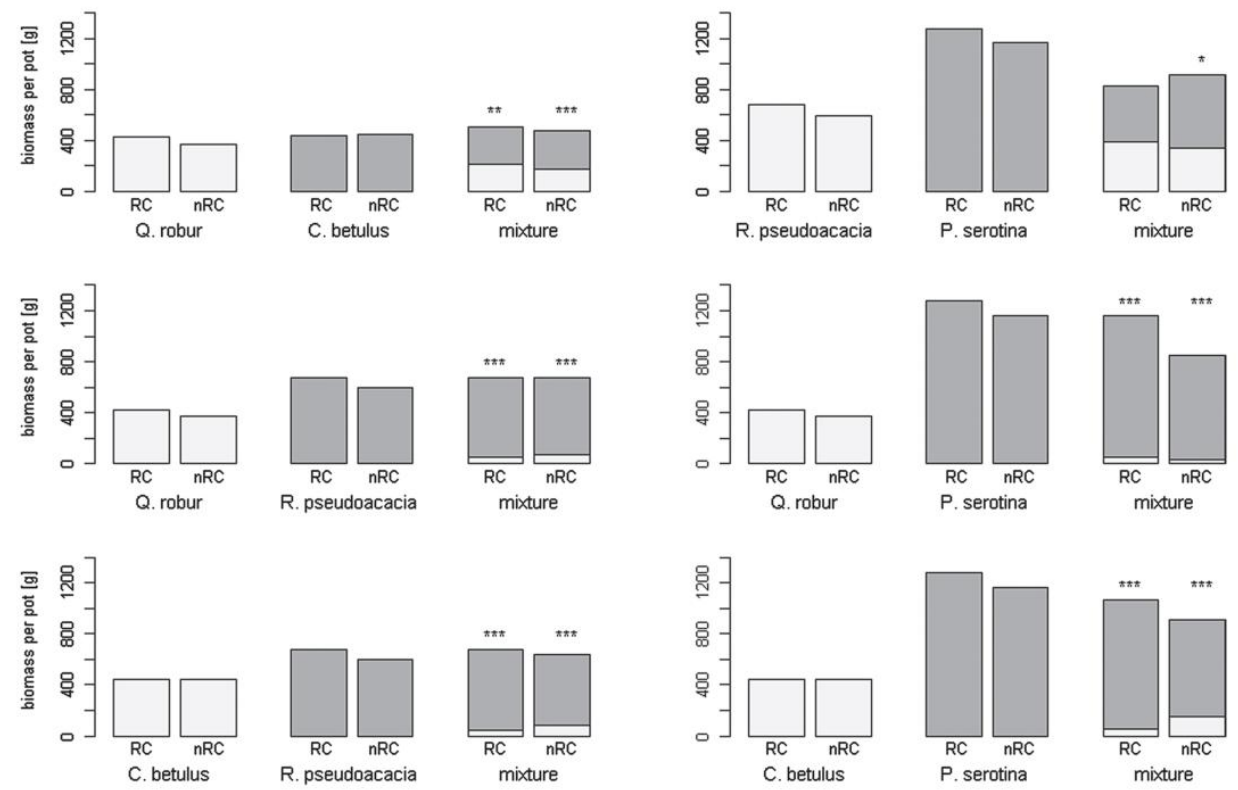

Figure 4: the first four bars in every figure show the mean biomass per pot of a given species in monoculture; the last two bars represent the proportion of the different species to total biomass in mixtures. Data are given for treatments with (RC) and without (nRC) root competition. Asterisks show significant differences between proportions of the different species in mixtures (ANOVA; ${ }^{*} P<0.05,{ }^{* *} P<0.01,{ }^{* * *} P<0.001$ )

\section{Biomass productivity of monocultures vs. mixtures}

Total pot biomass differed between mixtures and monocultures (Fig. 3). Independent of treatment or species mixture, Q. robur had the lowest pot biomass (Table 3, Figs 3 and 4). The highest productivity was observed for P. serotina monocultures (Figs 3 and 4). Only in one case we observed an underyielding of productivity, i.e. in the mixture of $R$. pseudoacacia and P. serotina exposed to RC (Fig. 3, Table 4). This mixture produced $15.15 \%$ less biomass than expected if no interaction had taken place (i.e. $\left[P_{\exp }=\right.$ productivity $_{\text {species } 1}$ in monoculture + productivity species 2 in monoculture]/2). The mean biomass of $P$. serotina in monoculture pots was approximately twice as high as the biomass of $R$. pseudoacacia. Biomass production per pot of the mixture of both exotic species was higher in the $\mathrm{nRC}$ than in the RC treatment, but the opposite was found in monocultures (Fig. 3). In all other mixtures, an overyielding of biomass productivity was found; three mixtures even showed transgressive overyielding (Table 4). Overyielding of all other mixtures compared to the expected productivity $\left(P_{\exp }\right)$ and the more productive monoculture ranged up to $38.75 \%$ for the mixture of Q. robur with P. serotina (nRC treatment, Table 4). The total pot biomasses of mixtures of $Q$. robur with C. betulus, Q. robur with R. pseudoacacia, and C. betulus with R. pseudoacacia were even higher than the biomass of the most productive monoculture, indicating transgressive overyielding. In all cases where exotic and native species were mixed, the exotic species were much more productive (Fig. 4). In general, mixtures of one native and one exotic species led to relative or even absolute biomass overyielding.

Table 4: non-transgressive and transgressive overyielding/ underyielding of mixtures with (RC) and without root competition (nRC). Relative percentage $\left(\Delta p_{\text {rel }}[\%]\right)$ shows the higher (positive values) or smaller (negative values) productivity of mixtures compared to the expected productivity calculated as the average of the two monocultures. Absolute percentage ( $\Delta p_{\mathrm{abs}}$ $[\%]$ ) refers to the productivity of the more productive species of a given mixture and shows transgressive overyielding of mixtures

\begin{tabular}{|c|c|c|c|c|c|}
\hline \multirow[b]{2}{*}{ Mixture of } & \multirow{2}{*}{$\begin{array}{l}\text { More } \\
\text { productive } \\
\text { species }\end{array}$} & \multicolumn{2}{|l|}{$\mathrm{RC}$} & \multicolumn{2}{|l|}{$\mathrm{nRC}$} \\
\hline & & $\Delta p_{\text {rel }}(\%)$ & $\Delta p_{\text {abs }}(\%)$ & $\Delta p_{\text {rel }}(\%)$ & $\Delta p_{\text {abs }}(\%)$ \\
\hline $\begin{array}{l}\text { Q. robur with } \\
\text { C. betulus }\end{array}$ & C. betulus & 15.49 & 14.61 & 17.26 & 7.45 \\
\hline $\begin{array}{l}\text { R. pseudoacacia with } \\
\text { P. serotina }\end{array}$ & P. serotina & -15.15 & - & 4.03 & - \\
\hline $\begin{array}{l}\text { Q. robur with } \\
\text { R. pseudoacacia }\end{array}$ & $\begin{array}{l}\text { R. pseudoa- } \\
\text { cacia }\end{array}$ & 22.49 & 0.46 & 38.75 & 12.69 \\
\hline $\begin{array}{l}\text { Q. robur with } \\
\text { P. serotina }\end{array}$ & P. serotina & 35.38 & - & 10.87 & - \\
\hline $\begin{array}{l}\text { C. betulus with } \\
\text { R. pseudoacacia }\end{array}$ & $\begin{array}{l}\text { R. pseudoa- } \\
\text { cacia }\end{array}$ & 21.20 & 0.01 & 23.36 & 7.93 \\
\hline $\begin{array}{l}\text { C. betulus with } \\
\text { P. serotina }\end{array}$ & P. serotina & 23.81 & - & 0.85 & - \\
\hline
\end{tabular}




\section{DISCUSSION}

\section{Are exotic species more competitive due to a higher productivity?}

Many studies suggest a better competitiveness of exotic tree and herbaceous species compared to native plants under adequate environmental conditions (Fuentes-Ramirez et al. 2011; Gorchov and Trisel 2003; Hager 2004; Littschwager et al. 2010; Osunkoya et al. 2005). Generally, invasive species, like $P$. serotina, are thought to be characterized by certain biological features giving them at least short-term advantages over native species. The predominance of invasive exotic species over native species is mainly related to a higher biomass production. Many studies confirmed biomass productivity being the most important attribute of highly competitive exotic tree species (e.g. Gyenge et al. 2008; Heidingsfelder and Knoke 2004; Hildebrandt et al. 2009; Lamarque et al. 2011). Like in other studies (e.g. Closset-Kopp et al. 2007; Lee et al. 2004), the two exotic species, $P$. serotina and $R$. pseudoacacia, showed a significant higher biomass production compared to the native species, Q. robur and C. betulus, in our experiment. According to MacArthur and Wilson (2001), high growth rates, especially during the first years of life, are a typical attribute of r-strategists, which generally dominate plant communities in early successional stages (Closset-Kopp et al. 2007). However, $P$. serotina seems to be able to ensure a permanent existence being adapted to various stages of succession (Closset-Kopp et al. 2007). Due to their fast growth combined with high fecundity, exotic species, like $P$. serotina, are able to rapidly occupy new habitats, giving inferior native species no chance to establish (Closset-Kopp et al. 2011). Another important characteristic of $P$. serotina seedlings is their ability to survive under shady conditions under closed canopies ('Oskar syndrome') and to grow rapidly when light conditions improve (Closset-Kopp et al. 2007; Silvertown 1984). Hence, on the one hand, P. serotina behaves as a shade-tolerant $\mathrm{K}$-strategist focusing on persistence in juvenile stages. On the other hand, this species seems to be a superior competitor in gaps by shifting towards fast growth responses and reproduction (r-strategist). This combination of traits may explain the high competitiveness and invasiveness of P. serotina. Other invasive exotic species, such as Acer platanoides in North America or Ailanthus altissima Mill. Swingle and R. pseudoacacia in Europe, are known to behave alike (ClossetKopp et al. 2007). In contrast to P. serotina, $R$. pseudoacacia is characterized as shade-intolerant (Motta et al. 2009; Rédei et al. 2012), but also has a rapid juvenile growth particularly under high light levels (González-Muñoz et al. 2011; Lee et al. 2004; Nasir et al. 2005).

In our experiment, it was evident that the exotic species had a strong negative impact on the growth of native species (Table 3, Fig. 4). Mean plant biomass of both native species decreased significantly when growing together in one pot with $P$. serotina or $R$. pseudoacacia. Interspecific competition with the exotic species had a much stronger influence on mean plant biomass than had interspecific competition with the other native species. The most evident reason for the superiority of the two exotic species in our experiment was their significantly higher biomass productivity resulting in a much higher competitiveness compared to Q. robur and C. betulus.

\section{Does root competition affect biomass production of the inferior species?}

Root competition affects plant growth in positive ways through niche partitioning and facilitation, but also in negative ways through competitive exclusion (Berendse 1982; Rajaniemi 2003; Silvertown 2004). Vertical belowground niche partitioning, i.e. the variation of the rooting depths, could not be studied here due to the limited pot height $(33 \mathrm{~cm})$. However, biomass production of the inferior species was lower when root competition by the exotic species took place, which may indicate competitive exclusion, simply by affecting space occupation. Hence, root competition seems to have an important influence on plant interactions for the studied species. Accordingly, Leuschner $e t$ al. (2001) assumed that the amount of belowground biomass of the superior competitor has a negative correlation to tree growth and vitality of inferior species in species mixtures. The strong competitiveness of the superior species led to a substantial decrease of the root biomass of the less competitive species. Similarly, in our study, the high competitive exotic species had negative effects on the biomass production-belowground as well as aboveground-of the native species. In mixtures with the native species, $R$. pseudoacacia as well as $P$. serotina had a significantly higher belowground biomass compared to monocultures. The two exotic species enhanced root growth in mixtures in order to pre-occupy the rooting space. Other studies found that competitive species are able to increase their fitness by growing roots into the soil shared with another co-occurring species. This does not only lead to an additional acquisition of resources from that space but also to a decreasing fitness of the competitors by reducing their resource supply (Aerts et al. 1991; Robinson et al. 1999). In our experiment, most of the available rooting capacity per pot was occupied by the exotic species. The two native species, Q. robur and C. betulus, only had limited access to free resources, resulting in reduced biomasses in mixtures with exotic species. Accordingly, Rewald and Leuschner (2009) found that Q. robur and C. betulus had the lowest belowground interspecific competitive ability compared to other native tree species. In the $\mathrm{nRC}$ treatment, inferior species were spatially separated belowground from the superior competitors. Rooting capacity of every tree was limited to one-fourth of the pot volume due to installed partitions, which had a negative effect on the growth of both exotic species. Our results showed that the inferior species managed to increase their biomass production when root competition was excluded. Thus, even a limited rooting volume seemed to provide better growing conditions than direct root interactions by superior competitors. 


\section{Do species mixtures produce more biomass than monocultures?}

In accordance with other studies (e.g. Bauhus et al. 2000; Brown 1992; Erskine et at. 2006; Pretzsch et al. 2010; Vilà et al. 2007), we found that species mixtures are more productive than are monocultures. Various reasons for this phenomenon, like niche partitioning and hence complementary resource use and facilitation, have been discussed in literature (Fridley 2001; Hector et al. 2002; Kelty 2006; Perot and Picard 2012; Pretzsch and Schütze 2009).

Mixtures of the two native species and mixtures of the native species with $R$. pseudoacacia showed transgressive overyielding, which means that the biomass production of the mixture was higher than that of the more productive species. In contrast, mixtures of both native species with $P$. serotina only resulted in non-transgressive overyielding. Thus, $P$. serotina was so much more productive in monoculture that the loss of total biomass, caused by the admixed native plants, was not counterbalanced by the remaining individuals. According to Loreau (2004), transgressive overyielding occurs if interspecific competition for both species is lower than intraspecific competition due to 'competitive reduction', i.e. the two species are subjected to reduced competition in mixture compared to monocultures (Pretzsch and Schütze 2009). However, in our study, in mixtures interspecific competition was lower than intraspecific interference for the exotic but not for the native species. Thus, transgressive overyielding may even occur if just one species in a mixture benefits from reduced intraspecific competition. For both native species, interspecific interactions with an exotic species had a stronger negative impact on biomass production than had intraspecific competition or interference by the other native species.

Even though $Q$. robur and C. betulus did not contribute to overyielding, they seemed to have a stimulating effect on the two exotic species based on their low competitiveness. Forrester et al. (2007) found the biomass production of the mixture of Eucalyptus globulus Labill. and Acacia mearnsii de Wildeman to be twice as high compared to monocultures of the two species growing on the same sites. The authors explained their finding with the nitrogen fixation of A. mearnsii. Therefore, it was expected that $R$. pseudoacacia, being also a nitrogen-fixing species, facilitates the growth of all other species in mixture by changing the soil conditions, causing overyielding in species mixtures (Forrester et al. 2006; Huston et al. 2000; Kowarik 2010). However, we found the opposite. In our pot experiment, $R$. pseudoacacia had always a negative impact on mean plant biomass of the admixed species. Mean plant biomass of $P$. serotina and the two native species was even lower in the RC treatment, which allowed root interactions. A possible explanation for not observing growth improvement by $R$. pseudoacacia may be that the soil used for the pot experiment was already fertilized with nitrogen. Hence, nitrogen may not have been the limiting resource. Bauhus et al. (2000) gave examples where nitrogen-fixing species have suppressed the growth of the admixed species.
If not nitrogen but other resources like phosphorus or water are limited, the nitrogen-fixing species have to compete for these resources, and thus there will be a shift from facilitation to competition.

In our experiment, only the mixture of the two exotic species, $R$. pseudoacacia and $P$. serotina, together did not show a positive mixing effect on the total biomass production (Table 4, Fig. 3). Interestingly this was only the case if root competition was not excluded. Thus, in the RC treatment, biomass productivity was $15.15 \%$ less than expected $\left(P_{\text {exp }}\right)$. The substantially lowered mean plant biomass of $P$. serotina when growing in mixture with $R$. pseudoacacia indicates a negative impact of $R$. pseudoacacia on $P$. serotina by root competition. Therefore, R. pseudoacacia seemed to be more effective in acquiring belowground resources if the two species grow together. However, the competitiveness of $P$. serotina compared to $R$. pseudoacacia may increase with decreasing light availability. It seems as if the ability of $R$. pseudoacacia to successfully compete for belowground resources is substantially reduced in the shade. However, this assumption could not be tested in our experiment as we could not realize another variant with reduced light. Actually, at the study site in Italy, P. serotina is more invasive under the canopy of overstorey trees than is R. pseudoacacia. Overall, the results of our study correspond quite nicely with the situation within the regeneration at the study site: the native species are much less competitive than the dominating R. pseudoacacia and P. serotina (Annighöfer et al. 2012).

It was evident that, in the early life stages of the investigated tree species, the native tree species are clearly inferiorespecially when they are exposed to root competition by the exotic species.

\section{ACKNOWLEDGEMENTS}

We would like to thank the Marianne and Dr. Fritz-Walter Fischer Foundation within the Stifterverband für die Deutsche Wissenschaft for funding our research and the DAAD (German Academic Exchange Service) VIGONI program for supporting project-based exchange. In addition, we thank Peter Annighöfer for linguistic corrections and two anonymous reviewers for valuable comments. Finally, we are especially grateful to the technical staff of the Department of Silviculture and Forest Ecology of the Temperate Zones and to all other helpers who were a big support while collecting the data.

\section{REFERENCES}

Aerts R, Boot R, van der Aart P (1991) The relation between aboveand belowground biomass allocation patterns and competitive ability. Oecologia 87:551-9.

Alpert P, Bone E, Holzapfel C (2000) Invasiveness, invasibility and the role of environmental stress in the spread of non-native plants. Perspect Plant Ecol Evol Syst 3:52-66.

Ammer C, Schall P, Wördehoff R, et al. (2011) Does tree seedling growth and survival require weeding of Himalayan balsam (Impatiens glandulifera)? Eur J For Res 130:107-16. 
Annighöfer P, Mölder I, Zerbe S, et al. (2012) Biomass functions for the two alien tree species Prunus serotina Ehrh. and Robinia pseudoacacia L. in floodplain forests of Northern Italy. Eur $J$ For Res 131:1619-35.

Bauhus J, Khanna PK, Menden N (2000) Aboveground and belowground interactions in mixed plantations of Eucalyptus globulus and Acacia mearnsii. Can J For Res 30:1886-94.

Berendse F (1982) Competition between plant populations with different rooting depths. Oecologia 53:50-5.

Bi H, Turvey ND, Heinrich P (1992) Rooting density and tree size of Pinus radiata (D. Don) in response to competition from Eucalyptus obliqua (L'Herit). For Ecol Manag 49:31-42.

Bray S, Kitajima K, Sylvia D (2003) Mycorrhizae differentially alter growth, physiology, and competitive ability of an invasive shrub. Ecol Appl 13:565-74.

Brown AHF (1992) Functioning of mixed-species stands at Gisburn, NW England. Spec Publ Br Ecol Soc 11:125-50.

Callaway RM, Aschehoug ET (2000) Invasive plants versus their new and old neighbors: a mechanism for exotic invasion. Science 290:521-3.

Cardinale BJ, Wright JP, Cadotte MW, et al. (2007) Impacts of plant diversity on biomass production increase through time because of species complementarity. Proc Natl Acad Sci US A 104:18123-8.

Casper BB, Jackson RB (1997) Plant competition underground. Annu Rev Ecol Syst 28:545-70.

Closset-Kopp D, Chabrerie O, Valentin B, et al. (2007) When Oskar meets Alice: does a lack of trade-off in $\mathrm{r} / \mathrm{K}$-strategies make Prunus serotina a successful invader of European forests? For Ecol Manag 247:120-30.

Closset-Kopp D, Saguez R, Decocq G (2011) Differential growth patterns and fitness may explain contrasted performances of the invasive Prunus serotina in its exotic range. Biol Invasions 13:1341-55.

Coomes DA, Grubb PJ (1998) Responses of juvenile trees to aboveand belowground competition in nutrient-starved Amazonian rain forest. Ecology 79:768-82.

Donald C (1958) The interaction of competition for light and for nutrients. Aust J Agric Res 9:421-35.

Dybzinski R, Fargione JE, Zak DR, et al. (2008) Soil fertility increases with plant species diversity in a long-term biodiversity experiment. Oecologia 158:85-93.

Erskine PD, Lamb D, Bristow M (2006) Tree species diversity and ecosystem function: can tropical multi-species plantations generate greater productivity? For Ecol Manag 233:205-10.

Forrester DI, Bauhus J, Cowie AL, et al. (2006) Mixed-species plantations of Eucalyptus with nitrogen-fixing trees: a review. For Bcol Manag 233:211-30.

Forrester DI, Schortemeyer M, Stock WD, et al. (2007) Assessing nitrogen fixation in mixed- and single-species plantations of Eucalyptus globulus and Acacia mearnsii. Tree Physiol 27:1319-28.

Fredericksen T, Zedaker S (1995) Fine root biomass, distribution, and production in young pine-hardwood stands. New Forests 10:99-110.

Fridley JD (2001) The influence of species diversity on ecosystem productivity: how, where, and why? Oikos 93:514-26.

Fuentes-Ramirez A, Pauchard A, Cavieres LA, et al. (2011) Survival and growth of Acacia dealbata vs. native trees across an invasion front in south-central Chile. For Ecol Manag 261:1003-9.
Godefroid S, Phartyal S, Weyembergh G, et al. (2005) Ecological factors controlling the abundance of non-native invasive black cherry (Prunus serotina) in deciduous forest understory in Belgium. For Ecol Manag 210:91-105.

González-Muñoz N, Castro-Díez P, Fierro-Brunnenmeister N (2011) Establishment success of coexisting native and exotic trees under an experimental gradient of irradiance and soil moisture. Environ Manage 48:764-73.

Gorchov DL, Trisel DE (2003) Competitive effects of the invasive shrub, Lonicera maackii (Rupr.) Herder (Caprifoliaceae), on the growth and survival of native tree seedlings. Plant Ecol 166:13-24

Gurevitch J, Howard TG, Ashton IW, et al. (2008) Effects of experimental manipulation of light and nutrients on establishment of seedlings of native and invasive woody species in Long Island, NY forests. Biol Invasions 10:821-31.

Gyenge JE, Fernandez ME, Schlichter TM (2008) Are differences in productivity between native and exotic trees in NW Patagonia related to differences in hydraulic conductance? Trees 22:483-90.

Hager HA (2004) Competitive effect versus competitive response of invasive and native wetland plant species. Oecologia 139:140-9.

Hector A (2006) Overyielding and stable species coexistence. New Phytol 172:1-3.

Hector A, Bazeley-White E, Loreau M, et al. (2002) Overyielding in grassland communities: testing the sampling effect hypothesis with replicated biodiversity experiments. Ecol Lett 5:502-11.

Hector A, Schmid B, Beierkuhnlein C, et al. (1999) Plant diversity and productivity experiments in European grasslands. Science 286:1 123-7.

Heidingsfelder A, Knoke T (2004) Douglasie versus Fichte. Sauerländer: Frankfurt am Main.

Hildebrandt P, Kirchlechner P, Hahn A, et al. (2009) Mixed species plantations in Southern Chile and the risk of timber price fluctuation. Eur J For Res 129:935-46.

Huston MA, Aarssen LW, Austin MP, et al. (2000) No consistent effect of plant diversity on productivity. Science 289:1255.

Jacob M, Leuschner C, Thomas FM (2010) Productivity of temperate broad-leaved forest stands differing in tree species diversity. Ann For Sci 67:503.

Kelty MJ (1992) Comparative productivity of monocultures and mixed-species stands. In Kelty MJ, Larson BC, Oliver CD (eds). The Ecology and Silviculture of Mixed-Species Forests. Dordrecht: Kluwer Academic Publishers, 125-41.

Kelty MJ (2006) The role of species mixtures in plantation forestry. For Ecol Manag 233:195-204.

Kleinbauer I, Dullinger S, Peterseil J, et al. (2010) Climate change might drive the invasive tree Robinia pseudacacia into nature reserves and endangered habitats. Biol Conserv 143:382-90.

Knight KS, Oleksyn J, Jagodzinski AM, et al. (2008) Overstorey tree species regulate colonization by native and exotic plants: a source of positive relationships between understorey diversity and invasibility. Divers Distrib 14:666-75.

Kowarik I (2010) Biologische Invasionen. Stuttgart: Ulmer.

Lamarque LJ, Delzon S, Lortie CJ (2011) Tree invasions: a comparative test of the dominant hypotheses and functional traits. Biol Invasions 13:1969-89. 
Lee C, Cho H, Yi H (2004) Stand dynamics of introduced black locust (Robinia pseudoacacia L.) plantation under different disturbance regimes in Korea. For Ecol Manag 189:281-93.

Leuschner C, Hertel D, Coners H, et al. (2001) Root competition between beech and oak: a hypothesis. Oecologia 126:276-84.

Littschwager J, Lauerer M, Blagodatskaya E, et al. (2010) Nitrogen uptake and utilisation as a competition factor between invasive Duchesnea indica and native Fragaria vesca. Plant Soil 331:105-14.

Loreau M (2004) Does functionalredundancy exist? Oikos 104:606-11.

MacArthur R, Wilson E (2001) The Theory of Island Biogeography, 13th ed. Princeton: Princeton University Press.

McPhee CS, Aarssen LW (2001) The separation of above- and belowground competition in plants: a review and critique of methodology. Plant Bcol 152:119-36.

Meinen C, Leuschner C, Ryan NT, et al. (2009) No evidence of spatial root system segregation and elevated fine root biomass in multispecies temperate broad-leaved forests. Trees 23:941-50.

Morrison JA, Mauck K (2007) Experimental field comparison of native and non-native maple seedlings: natural enemies, ecophysiology, growth and survival. J Ecol 95:1036-49.

Motta R, Nola P, Berretti R (2009) The rise and fall of the black locust (Robinia pseudoacacia L.) in the "Siro Negri" Forest Reserve (Lombardy, Italy): lessons learned and future uncertainties. Ann For Sci 66:410.

Nasir H, Iqbal Z, Hiradate S, et al. (2005) Allelopathic potential of Robinia pseudo-acacia L. JChem Bcol 31:2179-92.

Osunkoya OO, Othman FE, Kahar RS (2005) Growth and competition between seedlings of an invasive plantation tree, Acacia mangium, and those of a native Borneo heath-forest species, Melastoma beccarianum. Ecol Res 20:205-14.

Perot T, Picard N (2012) Mixture enhances productivity in a two-species forest: evidence from a modeling approach. Ecol Res 27:83-94.

Pretzsch H (2005) Diversity and productivity in forests: evidence from long-term experimental plots. In Scherer-Lorenzen $M$, Körner C, Schulze E-D (eds). Forest Diversity and Function. Berlin/Heidelberg: Springer, 4l-64.

Pretzsch H, Block J, Dieler J, et al. (2010) Comparison between the productivity of pure and mixed stands of Norway spruce and European beech along an ecological gradient. Ann For Sci 67:712.

Pretzsch H, Schütze G (2009) Transgressive overyielding in mixed compared with pure stands of Norway spruce and European beech in Central Europe: evidence on stand level and explanation on individual tree level. Eur J For Res 128:183-204.

Pyšek P, Richardson DM (2008) Traits associated with invasiveness in alien plants: where do we stand? Biol Invasions 193:97-125.

R Development Core Team (2012) R: A Language and Environment for Statistical Computing. Vienna, Austria: R Foundation for Statistical Computing. http://www.R-project.org.
Rajaniemi T (2003) Explaining productivity-diversity relationships in plants. Oikos 101:449-57.

Rédei K, Csiha I, Keserŭ Z, et al. (2012) The silviculture of black locust (Robinia pseudoacacia L.) in Hungary: a review. South-East Eur Forest 2:101-7.

Rejmanek M, Richardson DM (1996) What attributes make some plant species more invasive? Ecology 77:1655-61.

Rewald B, Leuschner C (2009) Belowground competition in a broadleaved temperate mixed forest: pattern analysis and experiments in a four-species stand. Eur J For Res 128:387-98.

Rice S, Westerman B, Federici R (2004) Impacts of the exotic, nitrogen-fixing black locust (Robinia pseudoacacia) on nitrogen-cycling in a pine-oak ecosystem. Plant Bcol 174:97-107.

Robinson D, Hodge A, Griffiths BS, et al. (1999) Plant root proliferation in nitrogen-rich patches confers competitive advantage. Proc $R$ Soc Lond Biol Sci 266:431-5.

Schenk HJ (2006) Root competition: beyond resource depletion. Ecology 94:725-39.

Silvertown JW (1984) Introduction to Plant Population Ecology. London: Longman.

Silvertown J (2004) Plant coexistence and the niche. Trends Ecol Evol 19:605-11.

Snaydon RW (1971) An analysis of competition between plants of Trifolium repens L. populations collected from contrasting soils. $J$ Appl Ecol 8:687-97.

Starfinger U, Kowarik I, Rode M, et al. (2003) From desirable ornamental plant to pest to accepted addition to the flora? - the perception of an alien tree species through the centuries. Biol Invasions 5:323-35.

Szwagrzyk J, Gazda A (2007) Above-ground standing biomass and tree species diversity in natural stands of Central Europe. $J$ Veg Sci 18:555-62.

Tilman D, Wedin D, Knops J (1996) Productivity and sustainability influenced by biodiversity in grassland ecosystems. Nature 379:718-20.

Vanhellemont M, Wauters L, Baeten L, et al. (2010) Prunus serotina unleashed: invader dominance after 70 years of forest development. Biol Invasions 12:1113-24.

Vilà M, Vayreda J, Gracia C, et al. (2003) Does tree diversity increase wood production in pine forests? Oecologia 135:299-303.

Vilà M, Vayreda J, Comas L, et al. (2007) Species richness and wood production: a positive association in Mediterranean forests. Ecol Lett 10:241-50.

Williamson MH, Fitter A (1996) The characters of successful invaders. Biol Conserv 78:163-70.

Wilson JB (1988) Shoot competition and root competition. J Appl Ecol 25:279-96. 
Chapter 4

\section{Back to the roots:}

how do seedlings of native tree species react to the competition by exotic species?

H. Kawaletz, I. Mölder, P. Annighöfer, A. Terwei, S. Zerbe, C. Ammer Annals of Forest Science DOI $10.1007 / \mathrm{s} 13595-013-0347-z$ 


\title{
Back to the roots: how do seedlings of native tree species react to the competition by exotic species?
}

\author{
Heike Kawaletz • Inga Mölder • Peter Annighöfer • \\ André Terwei $\cdot$ Stefan Zerbe $\cdot$ Christian Ammer
}

Received: 25 April 2013 / Accepted: 15 November 2013

(C) INRA and Springer-Verlag France 2013

\begin{abstract}
- Context Identifying the traits of exotic species may explain their invasiveness and help control the negative impacts of these species on native ecosystems. In this study, we investigated root competition as an important driver for the competitiveness of two exotic tree species in the seedling stage.

- Aims In a pot experiment, carried out in Central Europe, we studied the effect of root competition of two exotic tree species (Prunus serotina Ehrh. and Robinia pseudoacacia L.) on biomass allocation of two native ones (Quercus robur L. and Carpinus betulus L.).

- Methods Seedlings of these species were exposed to intraand interspecific mixtures with and without the effect of root competition. For this, belowground plastic partitions were installed in the pots.

- Results Competition intensity in the pots increased over time, irrespective of mixture type. However, this increase was much higher for the native species if mixed with the exotic species compared to monocultures or inter-native
\end{abstract}

Handling Editor: Gilbert Aussenac

Contribution of the co-authors Heike Kawaletz: designing the experiment, writing the paper, running the data analysis

Inga Mölder: supervising the work, coordinating the research project

Peter Annighöfer, André Terwei: writing the paper

Stefan Zerbe, Christian Ammer: supervising the work, coordinating the research project

H. Kawaletz $(\bowtie) \cdot$ P. Annighöfer $\cdot$ C. Ammer

Department of Silviculture and Forest Ecology of the Temperate

Zones, University of Göttingen, Büsgenweg 1, 37077 Göttingen,

Germany

e-mail: hkawale@gwdg.de

I. Mölder

Energieagentur Region Göttingen e.V., Berliner Str. 2,

37073 Göttingen, Germany

A. Terwei $\cdot$ S. Zerbe

Faculty of Science and Technology, Free University

of Bozen-Bolzano, piazza Università 5, 39100 Bolzano, Italy mixtures. In addition to ontogeny, competition affected biomass allocation patterns. Under root competition by the exotic species, the native species preferentially allocated their biomass to the roots. A higher allocation to the roots was mainly achieved at the expense of leaf and branch biomass.

- Conclusion Root competition of $P$. serotina and $R$. pseudoacacia may be a reason for the lack of $Q$. robur and C. betulus in the seedling stage in natural environments where all four species occur.

Keywords Biomass allocation · Balanced growth hypothesis $\cdot$ Pot experiment $\cdot$ Prunus serotina $\cdot$ Robinia pseudoacacia

\section{Introduction}

In natural ecosystems, nutrients and other resources that are needed for tree growth, regeneration, and reproduction are usually limited. According to Goldberg (1990), a species is competitive if it combines two attributes: (1) being effective in acquiring resources to maintain its own fitness, i.e., reducing resource availability of competitors while increasing the own biomass, and (2) keeping growth and survival as high as possible if resource availability decreases. For both strategies, plasticity in biomass allocation is essential. Besides the effects of ontogeny, i.e., plant size, biomass allocation is therefore to a considerable amount driven by resource availability (Schall et al. 2012). As suggested by the balanced growth hypothesis (Shipley and Meziane 2002), under restricted resource availability, plants increase the efficiency in resource uptake and/or allocate more biomass to those compartments, which are involved in the acquisition of the primarily limiting resource. Numerous studies showed an effect of aboveground (shoot) competition on biomass partitioning (e.g., Horn 1971; Nilsson and Albrektson 1993; Feng et al. 2007). In case of strong shading, plants allocate more biomass to the aboveground 
organs, especially to the leaves, in order to maximize photosynthesis (van Hees 1997; Ammer 2003; Hofmann and Ammer 2008). Although belowground (root) competition is as important as aboveground interactions (Wilson 1988; Casper and Jackson 1997; Cahill 2003), there is less information on how tree species change biomass allocation patterns in response to belowground competition (Haase 2009). However, according to the balanced growth hypothesis, biomass will be allocated to the roots if nutrients or water becomes the limiting factor for growth (e.g., Ibrahim et al. 1998; Bloor et al. 2008; Kleczewski et al. 2012). By changing biomass allocation patterns, plants therefore respond to changes in resource availability, which may be interpreted as an adaptation to stress (e.g., Shipley and Meziane 2002; Delagrange et al. 2004; Curt et al. 2005). According to Weiner (2004), plasticity in biomass allocation is important for plant survival, e.g., under competitive situations. In environments of low soil water or nutrient availability, the proportion of root biomass may therefore be treated as a measure of competition pressure from neighboring plants (Aerts et al. 1991; Cahill 2003; Bloor et al. 2008).

In many ecosystems, invasive exotic species are able to alter the environmental conditions such as the nutrient and hydrologic cycle (Mack et al. 2000) and may negatively affect the abundance or survival of native species due to a higher biomass production (e.g., Morrison and Mauck 2007; Pyšek and Richardson 2008; Lamarque et al. 2011). The high biomass production in the early stages, indicating a strong competitiveness in the regeneration phase, leads to resource depletion, hampering the growth of neighboring plants.

The two North American tree species black cherry (Prunus serotina Ehrh.) and black locust (Robinia pseudoacacia L.) have managed to successfully spread throughout Europe. Both species are among the 18 most invasive terrestrial plant species (DAISIE Project 2009). They are considered to be under the most aggressive exotic tree species in European forests and are regarded as strong competitors of native tree species (e.g., Kleinbauer et al. 2010; Vanhellemont et al. 2010). P. serotina was one of the first North American tree species that was introduced to Europe (Starfinger et al. 2003). It is able to alter biodiversity if it occurs in monospecific stands that impede native tree regeneration (Closset-Kopp et al. 2007). Due to its ability to fix nitrogen, R. pseudoacacia especially is a threat for the identity and integrity of nutrientpoor sites where it can change soil conditions and alter species compositions (Rice et al. 2004; Motta et al. 2009; Annighöfer et al. 2012). On several sites in Europe, $P$. serotina and $R$. pseudoacacia negatively affect the regeneration of cooccurring native species. An example is the low abundance of Quercus robur L. and Carpinus betulus L. in North Italian floodplain forests (Annighöfer et al. 2012; Terwei et al. 2013). In Central Europe, Q. robur is one of the most frequent deciduous forest tree species. It has a high demand for light and is not able to successfully compete with species casting deep shade. $C$. betulus is a late successional, shade-tolerant species and is often associated with $Q$. robur in QuercoCarpinetum forests that can be found on the most fertile soils in temperate Europe (Ellenberg 1988).

Actually, in a pot experiment containing mixtures of exotic $P$. serotina and R. pseudoacacia and the two native species $Q$. robur and $C$. betulus, strongly changed biomass production was observed (Kawaletz et al. 2013). In the regarding experiment, the competition and growth response of the four species in monocultures and mixtures were studied under controlled conditions. Whereas biomass production of the species in different inter- and intraspecific competitive situations was the main focus of a previous article (Kawaletz et al. 2013), biomass allocation pattern is addressed in the present study. We tested the following hypotheses: (1) competition by exotic $P$. serotina and $R$. pseudoacacia on native $Q$. robur and $C$. betulus under open field conditions is much stronger than that of intraspecific or inter-native interference and (2) the proportion of root biomass of a seedling increases with increasing root competition intensity.

\section{Methods}

\subsection{Experimental setup}

A controlled pot experiment was conducted under outdoors conditions in Göttingen, Germany (see also Kawaletz et al. 2013). The experimental site was located at $170 \mathrm{~m}$ above sea level. The climate is temperate with an average annual precipitation of $644.9 \mathrm{~mm}$ and most of the rain falling in June $(81.3 \mathrm{~mm})$. The average monthly temperature ranges from 4.8 to $13{ }^{\circ} \mathrm{C}$, with a mean annual temperature of about $8.7^{\circ} \mathrm{C}$ (Wetterstation Göttingen 2013).

Four tree species were used for the pot experiment: pedunculate oak $(Q$. robur $)$ and hornbeam $(C$. betulus $)$ were chosen as native species; black cherry $(P$. serotina $)$ and black locust (R. pseudoacacia) represented the exotic species in the experiment. The seedlings of each tree species were obtained from a nursery in Germany (Münchehof, Lower Saxony) to minimize transport-induced damages. In spring 2010, the 1-year-old seedlings were planted in pots with a volume of 651 (diameter, $54 \mathrm{~cm}$; height, $33 \mathrm{~cm}$ ). Prior to planting, each pot was filled with $5 \mathrm{~cm}$ coarse gravel to ensure drainage and with fertilized potting soil (Einheitserde-und Humuswerke, Gebr. Patzer GmbH \& Co. KG, Sinntal-Jossa/Germany, type Eurohum $\mathrm{CRH})$. The potting soil was used to ensure homogeneous substrate and nutrient conditions in every pot. The potting soil was coarsely structured and mainly contained peat and humus with a small fraction of sand and clay. The fertilizer content within the soil was $140 \mathrm{mg} / \mathrm{l}$ for nitrogen and phosphor and $200 \mathrm{mg} / \mathrm{l}$ for potassium. The tree seedlings were watered as

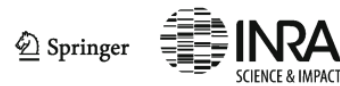


needed, with all pots receiving the same amount of water. Excess water drained through holes in the bottom of the pots. During winter, the pots were arranged close to each other and embedded in foliar litter to prevent frost damage to the roots. All pots were placed randomly on the area to avoid edge effects, i.e., differences in light and temperature conditions, etc. The distance between the pots was $1 \mathrm{~m}$, which ensured sufficient light supply for each plant. The plants were examined during two growing periods, beginning in April 2010 and ending in October 2011. Since Q. robur is a shade-intolerant species and we did not want to reduce its competiveness by shade, the study was carried out under full light. The growing conditions for all individuals and all species were similar.

Four seedlings were planted per pot and arranged in ten different species mixtures, of which four were monocultures and six were species mixtures. Every mixture consisted of not more than two species. The following six mixtures were used: (1) $Q$. robur with $C$. betulus, (2) R. psendoacacia with $P$. serotina, (3) $Q$. robur with $R$. pseudoacacia, (4) $Q$. robur with P. serotina, (5) C. betulus with $R$. pseudoacacia, and (6) $C$. betulus with $P$. serotina. There were 36 replicates for the monoculture pots and 60 replicates for each of the six species mixtures. Pots with dead seedlings had to be excluded from further analyses since even only one dead plant per pot would have changed the competitive situation compared to those pots containing four plants. Mortality reduced the number of pots from 504 to 201 (see number of individuals per treatment in Table 1).

\subsection{Competition treatments}

A modified "divided pot technique" was used to study the different effects of belowground (root) and aboveground (shoot) competition (Donald 1958; McPhee and Aarssen 2001). The pots were assigned to either root competition, shoot competition, or full competition (i.e., root and shoot competition) treatment. Pots without competition (no competition treatment) were excluded from the analysis because of insufficient data due to high mortality. The different competition treatments were achieved by installing aboveground and belowground partitions allowing only root or shoot competition, respectively. The above- and belowground partitions were made of white rigid PVC sheets since white aboveground partitions reflected the sunlight and thus leveled the light conditions on all four sections of the pot. However, in our experiment, shoot competition had no significant effect on tree growth within a mixture type (data not shown). We therefore pooled the two treatments in which the seedlings were exposed to root competition (i.e., root and full competition) and compared them with the treatment without root competition (i.e., shoot competition treatment). Therefore, "root competition" (RC) was contrasted with "no root competition" (nRC).

\subsection{Measurements}

Seedling diameter ( $3 \mathrm{~cm}$ above ground) and height were measured for all seedlings at the start of the experiment and after two vegetation periods to calculate relative increment. To ensure an identical measuring point for each individual in every measuring campaign, the position was marked in 2010. At the end of the experiment, all pots with four living plants were harvested, resulting in a total of $n=804$ trees, of which $n=246$ were $Q$. robur, $n=240$ were $C$. betulus, $n=188$ were $R$. pseudoacacia , and $n=130$ were $P$. serotina seedlings (Table 1). The biomass of every tree seedling was assigned to stems, branches, roots, and leaves. The dry weight with an accuracy of $0.001 \mathrm{~g}$ was determined separately after drying all biomass compartments for 3 days at $70{ }^{\circ} \mathrm{C}$ in a temperaturecontrolled oven until a constant weight was achieved.

\subsection{Data analysis}

All statistical tests and the preparation of graphs were performed using the free software environment $R$ ( $R$ Development Core Team 2012). To avoid pseudoreplication, data were analyzed on the species level, i.e., data were averaged for the individuals of a given species per pot. Additionally, we performed a variance component analysis to ensure that pot effects can be excluded.

The Shapiro-Wilk normality test was used to analyze data distribution. To assess homoscedasticity, we used Levene's test. If data showed a normal distribution and if the variances were homogenous, we used an analysis of variance (ANOVA) and Tukey's range test to find significant differences between groups. If data could not be assumed to be normally distributed and/or did not show homoscedasticity, we used the Kruskal-Wallis test and applied pairwise comparisons with the Wilcoxon rank sum test. All tests comparing groups were two-sided.

To show how competition intensity changed over time in the different species mixtures, we calculated Lorimer's competition index for all trees of a pot (Lorimer 1983).

Lorimer's competition index $x_{i}=\sum_{j=1}^{n} d_{j} / d_{i}$

where $n$ is the number of competitors (in our case, $n=3$ ), $d_{j}$ is the diameter of the competitor $j$ (in millimeters), and $d_{i}$ is the diameter of the target tree $i$ (in millimeters) at a given time (in our case, start and end of the experiment). The competition index was averaged per species and pot.

The effect of factor levels (i.e., different species mixtures) on the biomass allocation to plant compartments were analyzed for both competition treatments individually using ANCOVA with tree size as covariate (model: factor+tree size) since plant biomass allocation is size-dependent (Schall et al. 
H. Kawaletz et al.

Table 1 Mean relative increment in seedling diameter and height \pm SE and number of plants per treatment $(n)$

\begin{tabular}{|c|c|c|c|c|c|c|}
\hline \multirow[t]{2}{*}{ Species } & & & \multicolumn{4}{|l|}{ Mixed with } \\
\hline & & & Quercus robur & Carpinus betulus & Robinia pseudoacacia & Prunus serotina \\
\hline \multirow[t]{10}{*}{ Quercus robur } & \multirow[t]{4}{*}{ Diameter } & \multirow[t]{2}{*}{$\mathrm{RC}$} & $1.31^{\mathrm{a}}$ & $1.30^{\mathrm{a}}$ & $0.52^{\mathrm{b}}$ & $0.33^{\mathrm{b}}$ \\
\hline & & & \pm 0.09 & \pm 0.11 & \pm 0.09 & \pm 0.06 \\
\hline & & \multirow[t]{2}{*}{$\mathrm{nRC}$} & $1.47^{\mathrm{a}}$ & $1.17^{\mathrm{ab}}$ & $0.74^{b c}$ & $0.33^{\mathrm{c}}$ \\
\hline & & & \pm 0.17 & \pm 0.11 & \pm 0.08 & \pm 0.08 \\
\hline & \multirow[t]{4}{*}{ Height } & \multirow[t]{2}{*}{$\mathrm{RC}$} & $1.66^{\mathrm{a}}$ & $1.63^{\mathrm{a}}$ & $0.44^{\mathrm{b}}$ & $0.45^{\mathrm{b}}$ \\
\hline & & & \pm 0.14 & \pm 0.17 & \pm 0.08 & \pm 0.47 \\
\hline & & \multirow[t]{2}{*}{$\mathrm{nRC}$} & $1.51^{\mathrm{a}}$ & $1.71^{\mathrm{a}}$ & $0.45^{\mathrm{b}}$ & $0.29^{b}$ \\
\hline & & & \pm 0.25 & \pm 0.21 & \pm 0.12 & \pm 0.10 \\
\hline & \multirow[t]{2}{*}{$n$} & $\mathrm{RC}$ & 72 & 40 & 28 & 22 \\
\hline & & $\mathrm{nRC}$ & 24 & 32 & 18 & 10 \\
\hline \multirow[t]{10}{*}{ Carpinus betulus } & \multirow[t]{4}{*}{ Diameter } & \multirow[t]{2}{*}{$\mathrm{RC}$} & $2.79^{\mathrm{a}}$ & $2.58^{\mathrm{a}}$ & $1.02^{b}$ & $1.09^{b}$ \\
\hline & & & \pm 0.17 & \pm 0.16 & \pm 0.13 & \pm 0.13 \\
\hline & & \multirow[t]{2}{*}{$\mathrm{nRC}$} & $3.08^{\mathrm{a}}$ & $2.75^{\mathrm{a}}$ & $1.31^{\mathrm{b}}$ & $2.35^{\mathrm{ab}}$ \\
\hline & & & \pm 0.20 & \pm 0.24 & \pm 0.11 & \pm 0.41 \\
\hline & \multirow[t]{4}{*}{ Height } & \multirow[t]{2}{*}{$\mathrm{RC}$} & $4.79^{a}$ & $4.18^{\mathrm{a}}$ & $1.87^{\mathrm{b}}$ & $1.51^{\mathrm{b}}$ \\
\hline & & & \pm 0.34 & \pm 0.23 & \pm 0.29 & \pm 0.25 \\
\hline & & \multirow[t]{2}{*}{$\mathrm{nRC}$} & $4.55^{\mathrm{a}}$ & $4.75^{\mathrm{a}}$ & $2.14^{\mathrm{b}}$ & $2.54^{\mathrm{ab}}$ \\
\hline & & & \pm 0.38 & \pm 0.39 & \pm 0.26 & \pm 0.52 \\
\hline & \multirow[t]{2}{*}{$n$} & $\mathrm{RC}$ & 40 & 60 & 32 & 24 \\
\hline & & $\mathrm{nRC}$ & 32 & 32 & 14 & 6 \\
\hline \multirow[t]{10}{*}{ Robinia pseudoacacia } & \multirow[t]{4}{*}{ Diameter } & \multirow[t]{2}{*}{$\mathrm{RC}$} & $3.28^{\mathrm{a}}$ & $3.31^{\mathrm{a}}$ & $2.25^{\mathrm{b}}$ & $2.46^{\mathrm{ab}}$ \\
\hline & & & \pm 0.29 & \pm 0.26 & \pm 0.16 & \pm 0.20 \\
\hline & & \multirow[t]{2}{*}{$\mathrm{nRC}$} & $2.91^{\mathrm{a}}$ & $2.97^{\mathrm{a}}$ & $2.46^{\mathrm{a}}$ & $2.14^{\mathrm{a}}$ \\
\hline & & & \pm 0.22 & \pm 0.23 & \pm 0.12 & \pm 0.22 \\
\hline & \multirow[t]{4}{*}{ Height } & \multirow[t]{2}{*}{$\mathrm{RC}$} & $5.83^{\mathrm{a}}$ & $6.23^{\mathrm{a}}$ & $3.93^{\mathrm{a}}$ & $6.52^{\mathrm{a}}$ \\
\hline & & & \pm 1.27 & \pm 1.94 & \pm 0.86 & \pm 2.62 \\
\hline & & \multirow[t]{2}{*}{$\mathrm{nRC}$} & $11.59^{\mathrm{a}}$ & $8.89^{\mathrm{a}}$ & $6.54^{\mathrm{b}}$ & $4.95^{\mathrm{b}}$ \\
\hline & & & \pm 3.37 & \pm 2.60 & \pm 1.92 & \pm 1.65 \\
\hline & $n$ & $\mathrm{RC}$ & 28 & 32 & 44 & 16 \\
\hline & & $\mathrm{nRC}$ & 18 & 14 & 28 & 8 \\
\hline Prunus serotina & Diameter & $\mathrm{RC}$ & $5.58^{\mathrm{a}}$ & $5.62^{\mathrm{a}}$ & $4.37^{\mathrm{b}}$ & $4.54^{\mathrm{b}}$ \\
\hline & & & \pm 0.26 & \pm 0.23 & \pm 0.29 & \pm 0.30 \\
\hline & & $\mathrm{nRC}$ & $5.46^{\mathrm{a}}$ & $4.90^{\mathrm{ab}}$ & $4.03^{b}$ & $4.51^{\mathrm{b}}$ \\
\hline & & & \pm 0.29 & \pm 0.49 & \pm 0.14 & \pm 0.18 \\
\hline & Height & $\mathrm{RC}$ & $1.81^{\mathrm{a}}$ & $1.93^{\mathrm{a}}$ & $1.27^{\mathrm{b}}$ & $1.71^{\mathrm{a}}$ \\
\hline & & & \pm 0.17 & \pm 0.22 & \pm 0.13 & \pm 0.16 \\
\hline & & $\mathrm{nRC}$ & $1.63^{\mathrm{a}}$ & $1.53^{\mathrm{a}}$ & $1.09^{\mathrm{a}}$ & $1.88^{\mathrm{a}}$ \\
\hline & & & \pm 0.16 & \pm 0.12 & \pm 0.08 & \pm 0.38 \\
\hline & $n$ & $\mathrm{RC}$ & 22 & 24 & 16 & 20 \\
\hline & & $\mathrm{nRC}$ & 10 & 6 & 8 & 24 \\
\hline
\end{tabular}

Data are shown for monocultures and mixtures with (RC) or without (nRC) root competition. Different lowercase letters indicate significant differences between the species mixtures in both competition treatments (Wilcoxon rank sum test, two-sided: $P<0.05$ )

2012). Differences between factor levels were determined using Tukey's HSD test for linear models (R package multcomp: $P<0.05$ ). The effect of experimental factors on the relationship between root and total biomass was analyzed using linear models also taking the interaction of factor levels and size (total biomass) into account. The minimal adequate model was determined using the backward model simplification method $(P<0.05$; Crawley 2007).

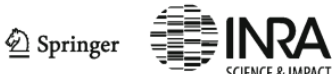




\section{Results}

\subsection{Mortality}

The mortality rate was significantly higher for $P$. serotina (45\%) and $R$. pseudoacacia (24\%) than for $Q$. robur $(13 \%)$ and $C$. betulus $\left(10 \% ; \chi^{2}\right.$ test: $\left.P<0.001\right)$. However, there were neither significant differences between the competition treatments nor between the species mixtures (data not shown). The majority of all dead tree seedlings died during the first few weeks after planting.

\subsection{Relative increment in seedling diameter and height}

The relative increment in seedling diameter and height differed considerably between all species after two vegetation periods (Table 1). In general, relative diameter increment averaged for all species mixtures and competition treatments was lowest for $Q$. robur (1.06), followed by $C$. betulus (2.27) and $R$. pseudoacacia (2.79), and was significantly highest for $P$. serotina (4.98). Interestingly, the mean relative height increment of $P$. serotina was considerably lower compared to $C$. betulus and $R$. pseudoacacia. For both native species, the relative increment in diameter and height were significantly lower in mixtures with one of the exotic species than in monocultures or mixtures with each other. The relative increments in the diameter and height of $R$. pseudoacacia and $P$. serotina were higher if mixed with one of the native species than in monocultures. The highest final
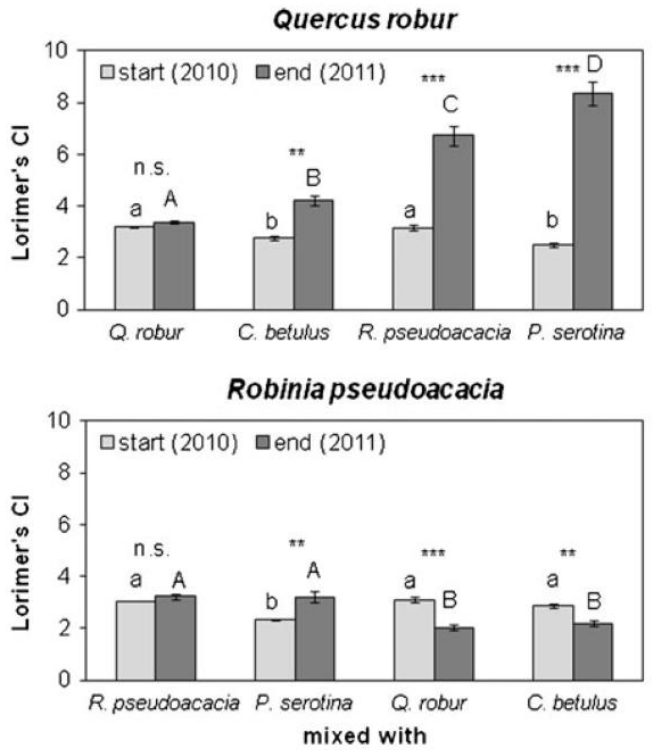

Fig. 1 Bar plots show Lorimer's competition index at the start (April 2010) and at the end (October 2011) of the pot experiment (averaged for each species per pot). Data are given for the different tree species in monoculture and species mixtures averaged for the two competition treatments (RC and $\mathrm{nRC})$. Asterisks show the significant differences diameters were reached by $P$. serotina in a mixture with one of the native species $(24.96 \mathrm{~mm}$ averaged for both competition treatments; data not shown). Mean stem height was highest for $R$. pseudoacacia when growing together with one of the native species $(155.81 \mathrm{~cm})$. In contrast, $Q$. robur had the lowest averaged diameter and height when mixed with $R$. pseudoacacia or P. serotina (diameter, $8.34 \mathrm{~mm}$; height, $37.19 \mathrm{~cm}$ ). For $C$. betulus, but not for $Q$. robur, the relative increments in diameter and height were higher in the $\mathrm{nRC}$ treatment when root competition with one of the exotic species was excluded (Table 1).

\subsection{Competition intensity}

Competition intensity, as calculated using Lorimer's competition index, did not differ significantly between the four species at the start of the experiment. In comparison with $C$. betulus and $P$. serotina, the initial tree dimensions were higher for $Q$. robur and R. pseudoacacia, thus leading to a lower Lorimer's competition index (Fig. 1). However, at the end of the experiment, it was about twice as high for $Q$. robur and $C$. betulus compared to $R$. pseudoacacia and $P$. serotina. Both exotic species exerted the strongest competitive pressure on both native species. For $Q$. robur, the mean Lorimer's competition index was significantly higher in a mixture with $P$. serotina (8.36) than with $R$. pseudoacacia (6.73). For $C$. betulus, there was no significant difference when growing with $R$. pseudoacacia or P. serotina. For both exotic species, competition intensity was significantly higher in monoculture or in a mixture with the other exotic
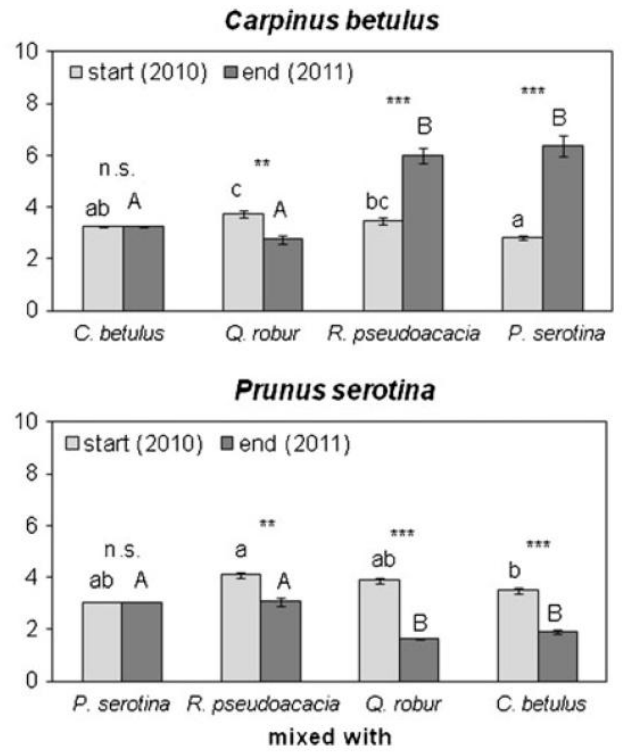

between start and end of the experiment for each species mixture (ANOVA: ${ }^{* * *} P<0.001,{ }^{* *} P<0.01,{ }^{*} P<0.05 ;$;.s. not significant). Different letters above each bar indicate significant differences between species mixtures at the start (small letters) and at the end (capital letters) of the experiment (ANOVA: $P<0.05$ ) 
H. Kawaletz et al.

Table 2 Mean biomass (in grams) of the different plant compartments (averaged for each species per pot)

\begin{tabular}{|c|c|c|c|c|c|c|}
\hline \multirow[t]{2}{*}{ Species } & \multicolumn{2}{|c|}{ Biomass compartment } & \multicolumn{4}{|l|}{ Mixed with } \\
\hline & & & Quercus robur & Carpinus betulus & Robinia pseudoacacia & Prunus serotina \\
\hline \multirow[t]{12}{*}{ Quercus robur } & \multirow[t]{2}{*}{ Total tree } & $\mathrm{RC}$ & $131.69^{\mathrm{a}}$ & $114.82^{\mathrm{a}}$ & $33.87^{b}$ & $27.65^{b}$ \\
\hline & & $\mathrm{nRC}$ & $116.33^{\mathrm{a}}$ & $120.33^{\mathrm{a}}$ & $41.56^{\mathrm{b}}$ & $33.03^{b}$ \\
\hline & \multirow[t]{2}{*}{ Belowground } & $\mathrm{RC}$ & $64.10^{\mathrm{a}}$ & $58.81^{\mathrm{a}}$ & $19.17^{\mathrm{b}}$ & $16.96^{\mathrm{b}}$ \\
\hline & & $\mathrm{nRC}$ & $58.24^{\mathrm{a}}$ & $57.30^{\mathrm{a}}$ & $25.44^{b}$ & $17.82^{b}$ \\
\hline & \multirow[t]{2}{*}{ Aboveground } & $\mathrm{RC}$ & $67.59^{\mathrm{a}}$ & $56.01^{\mathrm{a}}$ & $14.70^{\mathrm{b}}$ & $10.69^{\mathrm{b}}$ \\
\hline & & $\mathrm{nRC}$ & $58.09^{\mathrm{a}}$ & $63.03^{\mathrm{a}}$ & $19.11^{\mathrm{b}}$ & $15.21^{\mathrm{b}}$ \\
\hline & \multirow[t]{2}{*}{ Stem } & $\mathrm{RC}$ & $32.06^{\mathrm{a}}$ & $26.62^{\mathrm{a}}$ & $5.56^{\mathrm{b}}$ & $5.24^{\mathrm{b}}$ \\
\hline & & $\mathrm{nRC}$ & $23.42^{\mathrm{a}}$ & $27.13^{\mathrm{a}}$ & $8.51^{\mathrm{b}}$ & $5.01^{\mathrm{b}}$ \\
\hline & \multirow[t]{2}{*}{ Branch } & $\mathrm{RC}$ & $12.14^{\mathrm{a}}$ & $10.22^{\mathrm{a}}$ & $1.37^{\mathrm{b}}$ & $2.07^{\mathrm{b}}$ \\
\hline & & $\mathrm{nRC}$ & $11.15^{\mathrm{a}}$ & $12.70^{\mathrm{a}}$ & $2.90^{\mathrm{b}}$ & $6.08^{a b}$ \\
\hline & \multirow[t]{2}{*}{ Leaf } & $\mathrm{RC}$ & $23.39^{a}$ & $19.17^{\mathrm{a}}$ & $7.77^{\mathrm{b}}$ & $3.38^{\mathrm{b}}$ \\
\hline & & $\mathrm{nRC}$ & $23.52^{\text {a }}$ & $23.19^{\mathrm{a}}$ & $7.70^{\mathrm{b}}$ & $4.12^{\mathrm{b}}$ \\
\hline \multirow[t]{12}{*}{ Carpinus betulus } & \multirow[t]{2}{*}{ Total tree } & $\mathrm{RC}$ & $192.89^{\mathrm{a}}$ & $142.12^{\mathrm{a}}$ & $30.46^{\mathrm{b}}$ & $31.69^{\mathrm{b}}$ \\
\hline & & $\mathrm{nRC}$ & $187.19^{\mathrm{a}}$ & $141.34^{\mathrm{b}}$ & $51.71^{\mathrm{c}}$ & $96.53^{\mathrm{bc}}$ \\
\hline & \multirow[t]{2}{*}{ Belowground } & $\mathrm{RC}$ & $68.34^{\mathrm{a}}$ & $48.57^{\mathrm{b}}$ & $12.43^{\mathrm{c}}$ & $14.02^{\mathrm{c}}$ \\
\hline & & $\mathrm{nRC}$ & $72.02^{\mathrm{a}}$ & $51.84^{\mathrm{b}}$ & $22.21^{\mathrm{c}}$ & $40.72^{b c}$ \\
\hline & \multirow[t]{2}{*}{ Aboveground } & $\mathrm{RC}$ & $124.55^{\mathrm{a}}$ & $93.55^{\mathrm{a}}$ & $18.03^{b}$ & $17.67^{\mathrm{b}}$ \\
\hline & & $\mathrm{nRC}$ & $115.16^{\mathrm{a}}$ & $89.51^{\text {ab }}$ & $29.50^{\mathrm{c}}$ & $55.81^{\mathrm{bc}}$ \\
\hline & \multirow[t]{2}{*}{ Stem } & $\mathrm{RC}$ & $55.07^{\mathrm{a}}$ & $39.62^{\mathrm{a}}$ & $8.72^{\mathrm{b}}$ & $8.13^{\mathrm{b}}$ \\
\hline & & $\mathrm{nRC}$ & $47.27^{\mathrm{a}}$ & $35.57^{\mathrm{ab}}$ & $12.51^{\mathrm{c}}$ & $23.71^{\mathrm{bc}}$ \\
\hline & \multirow[t]{2}{*}{ Branch } & $\mathrm{RC}$ & $28.70^{\mathrm{a}}$ & $23.80^{\mathrm{a}}$ & $3.46^{\mathrm{b}}$ & $4.19^{b}$ \\
\hline & & $\mathrm{nRC}$ & $31.13^{\mathrm{a}}$ & $24.04^{\mathrm{a}}$ & $6.55^{\mathrm{b}}$ & $13.03^{\mathrm{ab}}$ \\
\hline & \multirow[t]{2}{*}{ Leaf } & $\mathrm{RC}$ & $40.78^{a}$ & $30.13^{\mathrm{a}}$ & $5.85^{\mathrm{b}}$ & $5.35^{\mathrm{b}}$ \\
\hline & & $\mathrm{nRC}$ & $36.76^{\mathrm{a}}$ & $29.90^{\mathrm{ab}}$ & $10.44^{\mathrm{c}}$ & $19.07^{\mathrm{bc}}$ \\
\hline \multirow[t]{12}{*}{ Robinia pseudoacacia } & \multirow[t]{2}{*}{ Total tree } & $\mathrm{RC}$ & $396.39^{\text {a }}$ & $399.84^{\mathrm{a}}$ & $253.70^{\mathrm{b}}$ & $251.24^{\mathrm{b}}$ \\
\hline & & $\mathrm{nRC}$ & $360.60^{\mathrm{a}}$ & $412.29^{\mathrm{a}}$ & $192.68^{b}$ & $236.82^{a b}$ \\
\hline & \multirow[t]{2}{*}{ Belowground } & $\mathrm{RC}$ & $115.48^{\mathrm{a}}$ & $117.13^{\mathrm{a}}$ & $73.38^{\mathrm{b}}$ & $88.20^{\mathrm{b}}$ \\
\hline & & $\mathrm{nRC}$ & $119.13^{\mathrm{a}}$ & $133.20^{\mathrm{a}}$ & $53.63^{\mathrm{b}}$ & $73.66^{\mathrm{ab}}$ \\
\hline & \multirow[t]{2}{*}{ Aboveground } & $\mathrm{RC}$ & $280.91^{\mathrm{ab}}$ & $282.71^{\mathrm{a}}$ & $180.32^{\mathrm{ab}}$ & $163.04^{\mathrm{b}}$ \\
\hline & & $\mathrm{nRC}$ & $241.47^{\mathrm{a}}$ & $279.09^{\mathrm{a}}$ & $139.05^{b}$ & $163.15^{\mathrm{ab}}$ \\
\hline & Stem & $\mathrm{RC}$ & $120.52^{\mathrm{a}}$ & $119.68^{\mathrm{a}}$ & $75.92^{b}$ & $69.16^{\mathrm{b}}$ \\
\hline & & $\mathrm{nRC}$ & $117.14^{\mathrm{a}}$ & $115.76^{\mathrm{a}}$ & $63.95^{\mathrm{b}}$ & $62.85^{\mathrm{b}}$ \\
\hline & Branch & $\mathrm{RC}$ & $72.54^{\mathrm{ab}}$ & $77.21^{\mathrm{a}}$ & $46.24^{\mathrm{ab}}$ & $37.27^{\mathrm{b}}$ \\
\hline & & $\mathrm{nRC}$ & $57.34^{\mathrm{ab}}$ & $69.31^{\mathrm{b}}$ & $31.05^{\mathrm{c}}$ & $34.70^{\mathrm{ac}}$ \\
\hline & Leaf & $\mathrm{RC}$ & $87.85^{\text {a }}$ & $85.82^{\mathrm{a}}$ & $58.16^{\mathrm{a}}$ & $56.61^{\mathrm{a}}$ \\
\hline & & $\mathrm{nRC}$ & $66.99^{\text {ab }}$ & $94.02^{b}$ & $44.04^{c}$ & $65.60^{\mathrm{ac}}$ \\
\hline Prunus serotina & Total tree & $\mathrm{RC}$ & $713.03^{\mathrm{a}}$ & $657.35^{\mathrm{ab}}$ & $299.3^{b}$ & $517.57^{\mathrm{ab}}$ \\
\hline & & $\mathrm{nRC}$ & $603.13^{\mathrm{a}}$ & $491.55^{\text {ab }}$ & $359.53^{\mathrm{b}}$ & $435.16^{\text {ab }}$ \\
\hline & Belowground & $\mathrm{RC}$ & $270.33^{a}$ & $269.17^{\mathrm{ab}}$ & $114.18^{\mathrm{b}}$ & $230.22^{\mathrm{ab}}$ \\
\hline & & $\mathrm{nRC}$ & $263.94^{\mathrm{a}}$ & $208.77^{\mathrm{ab}}$ & $159.18^{b}$ & $187.99^{b}$ \\
\hline & Aboveground & $\mathrm{RC}$ & $442.70^{\mathrm{a}}$ & $388.18^{a b}$ & $185.13^{\mathrm{b}}$ & $287.35^{\mathrm{ab}}$ \\
\hline & & $\mathrm{nRC}$ & $339.19^{\mathrm{a}}$ & $282.78^{a b}$ & $200.35^{\mathrm{b}}$ & $247.17^{\mathrm{ab}}$ \\
\hline & Stem & $\mathrm{RC}$ & $155.43^{\mathrm{a}}$ & $133.54^{\mathrm{ab}}$ & $64.10^{\mathrm{b}}$ & $114.32^{\mathrm{ab}}$ \\
\hline & & $\mathrm{nRC}$ & $113.93^{\text {a }}$ & $106.16^{\mathrm{ab}}$ & $79.06^{\mathrm{b}}$ & $88.66^{\mathrm{ab}}$ \\
\hline & Branch & $\mathrm{RC}$ & $130.06^{\mathrm{a}}$ & $114.83^{\mathrm{ab}}$ & $41.50^{\mathrm{b}}$ & $81.50^{\mathrm{ab}}$ \\
\hline & & $\mathrm{nRC}$ & $100.14^{\mathrm{a}}$ & $63.33^{\mathrm{ab}}$ & $48.28^{b}$ & $67.65^{\mathrm{ab}}$ \\
\hline & Leaf & $\mathrm{RC}$ & $157.21^{\mathrm{a}}$ & $139.81^{\text {ab }}$ & $79.53^{\mathrm{b}}$ & $91.53^{\text {ab }}$ \\
\hline
\end{tabular}

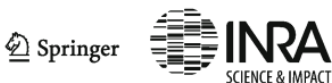


Effects of belowground competition

\begin{tabular}{|c|c|c|c|c|c|}
\hline \multirow[t]{2}{*}{ Species } & \multirow[t]{2}{*}{ Biomass compartment } & \multicolumn{4}{|l|}{ Mixed with } \\
\hline & & Quercus robur & Carpinus betulus & Robinia pseudoacacia & Prunus serotina \\
\hline & $\mathrm{nRC}$ & $125.12^{\mathrm{a}}$ & $113.29^{\mathrm{ab}}$ & $73.00^{b}$ & $86.97^{\mathrm{ab}}$ \\
\hline
\end{tabular}

Data are shown for monocultures and mixtures with $(\mathrm{RC})$ or without $(\mathrm{nRC})$ root competition. Different lowercase letters indicate significant differences between the species mixtures in both competition treatments (Wilcoxon rank sum test, two-sided: $P<0.05$ )

species compared to the mixtures with one of the native species at the end of the experiment.

A significant effect of the competition treatment ( $\mathrm{RC}$ and $\mathrm{nRC}$ ) could only be found for native species in mixtures with one of the exotic species. In these cases, Lorimer's competition index was higher in the RC than in the $\mathrm{nRC}$ treatment. However, for most species combinations, there were no significant differences between the two competition treatments. Therefore, both competition treatments were pooled to simplify Fig. 1.

\subsection{Biomass partitioning}

Independent of the applied competition treatment ( $\mathrm{RC}$ and $\mathrm{nRC}$ ), the strong competition pressure of both exotic species reduced the biomass of $Q$. robur and $C$. betulus due to the significantly higher biomasses of $R$. pseudoacacia and $P$. serotina (Table 2). All biomass compartments of $P$. serotina were highest in the mixture with $Q$. robur. In addition to the mixture effect, the influence of belowground competition (RC) led to a further biomass reduction for the native species in the mixture with $P$. serotina and $R$. pseudoacacia (Table 2 and Fig. 2, RC).

The proportions of the four biomass compartments differed between monocultures and species mixtures (Table 2). For $Q$. robur, biomass reduction of all compartments except for branch biomass was highest in the mixture with $P$. serotina, whereas $R$. pseudoacacia had the strongest negative effect on all biomass compartments of $C$. betulus. On average, for both native species, absolute biomass reduction was approximately $10 \%$ higher for the aboveground compartments than for the roots. For $Q$. robur, the strongest reduction was found for leaf biomass, which was reduced by $83 \%$ in the mixture with $P$. serotina. Branch biomass of $C$. betulus was reduced most strongly in both mixtures with exotic species $(-79 \%$ if mixed with $R$. pseudoacacia and $-64 \%$ if mixed with $P$. serotina, respectively). For P. serotina, the biomass of all compartments was higher in combination with $Q$. robur compared to mixtures with $R$. pseudoacacia. The biomass increment of $R$. pseudoacacia was higher for the roots than for the aboveground compartments, whereas for P. serotina it was the other way around. $Q$. robur had a most beneficial effect on the leaf
(59\%) and branch biomass (58\%) of P. serotina. When growing together in one pot, both exotic species influenced each other negatively. On the one hand, $R$. pseudoacacia slightly reduced the branch and root biomass of P. serotina (reductions of 39 and $33 \%$, respectively) in comparison with monocultures of $P$. serotina. On the other hand, if mixed with $P$. serotina, $R$. pseudoacacia showed reduced stem and branch biomass (reductions of 5 and $4 \%$, respectively).

Biomass partitioning was influenced by tree size, but not for all compartments (Table 3). Mixture type and competition treatment were found to affect biomass allocation as well (Fig. 2 and Tables 2 and 3). In the $\mathrm{RC}$ treatment, biomass partitioning between above- and belowground components was affected by mixture for all species (Fig. 2, RC). Both native species had a higher proportion of root biomass when exposed to interspecific root competition with $R$. pseudoacacia and $P$. serotina (Table 3 ). Accordingly, the averaged root-to-shoot ratio for both competition treatments of $Q$. robur was higher in the mixture with one of the exotic species (1.32 and 1.38 in the mixture with $R$. pseudoacacia and $P$. serotina, respectively) compared to monoculture (0.98) or if mixed with C. betulus (0.98; Table 2). In the RC treatment, the proportion of root biomass of $R$. pseudoacacia was highest in the mixture with $P$. serotina, but compared to monoculture, it did not change significantly in the mixture with $C$. betulus and $Q$. robur (Fig. 2, RC, and Table 3). Biomass allocation to the roots of $P$. serotina was highest in the mixture with $R$. pseudoacacia and - in contrast to all other specieswhen exposed to intraspecific competition and lowest in the mixture with $Q$. robur (Fig. 2, RC). In contrast to the RC treatment, a higher biomass allocation toward the roots as a function of species mixture was not found for the $\mathrm{nRC}$ treatment, except for Q. robur (Fig. 2, nRC).

Corresponding to the higher proportion of root biomass, the relative proportions of the leaf and branch biomass of $Q$. robur and $C$. betulus were lower in the mixture with exotic species than in monocultures or in the mixture with the other native species (Table 3). The proportions of the stem biomasses showed no significant difference between the species combinations. 
RC

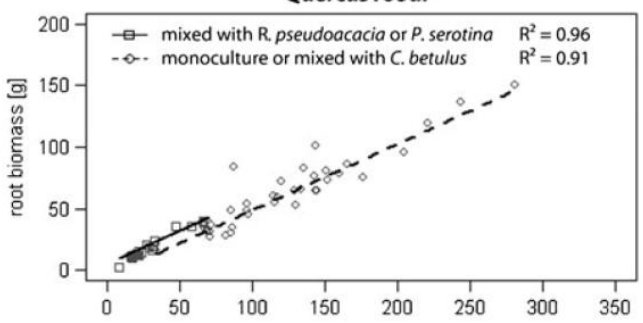

Robinia pseudoacacia

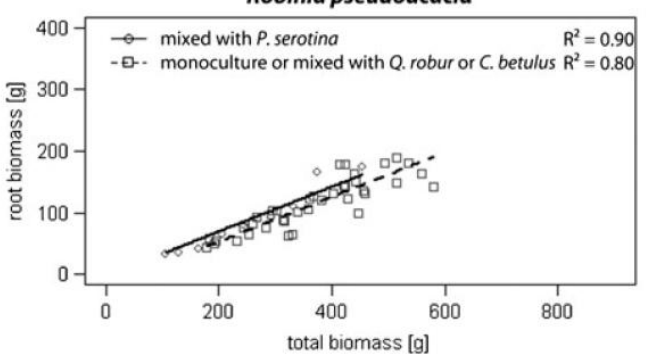

$\mathrm{nRC}$

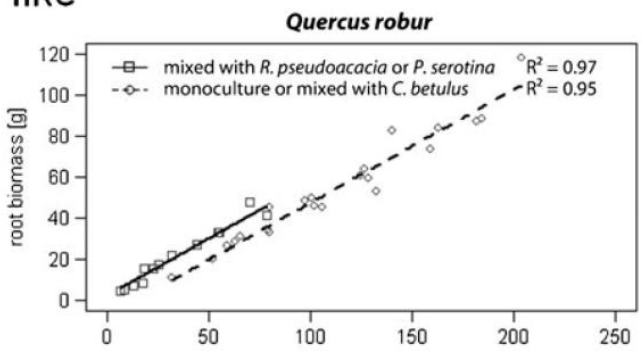

Robinia pseudoacacia

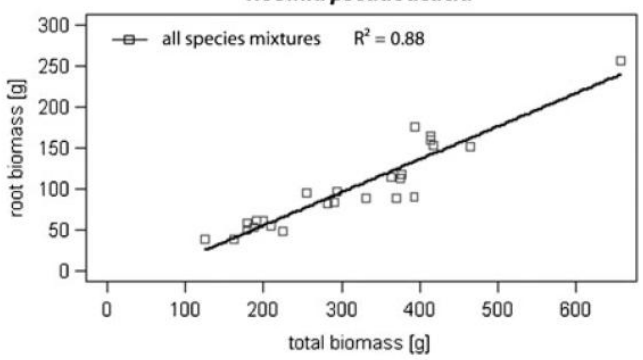

Fig. 2 Allometric relationship between root biomass and total biomass (averaged for each species per pot). Data are given for the different tree species in monoculture and species mixtures with root competition $(R C$, top four figures) or without root competition ( $n R C$, bottom four figures). Regression lines represent the minimal adequate models derived through

\section{Discussion}

4.1 Exotic species are strong competitors in the seedling phase

Our results revealed that $R$. pseudoacacia and P. serotina exerted a high competitive pressure on the two native species

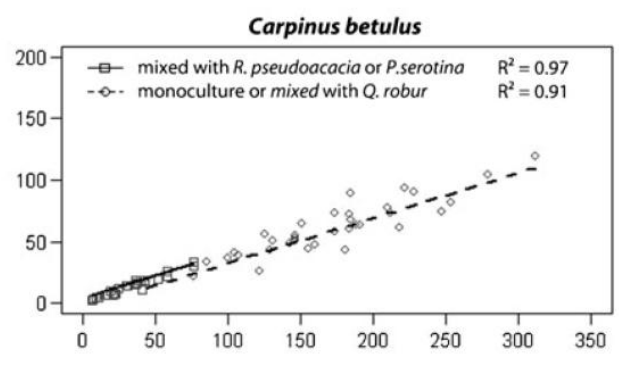

Prunus serotina

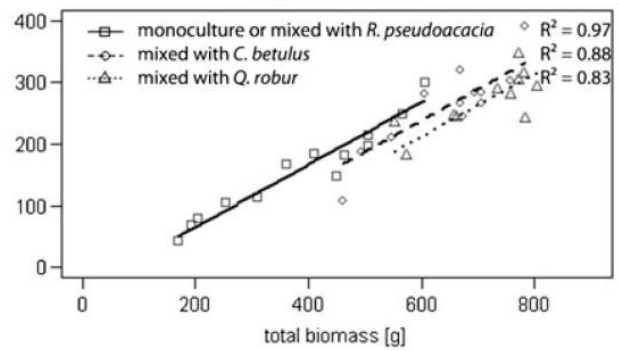

Carpinus betulus

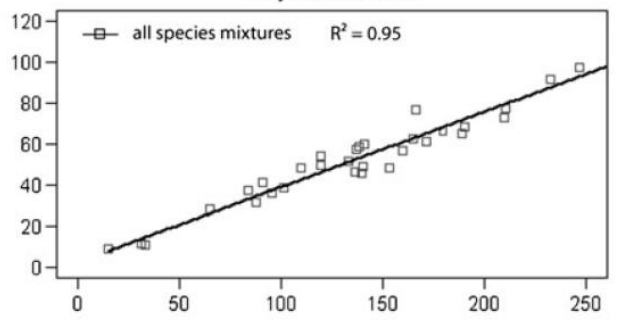

Prunus serotina

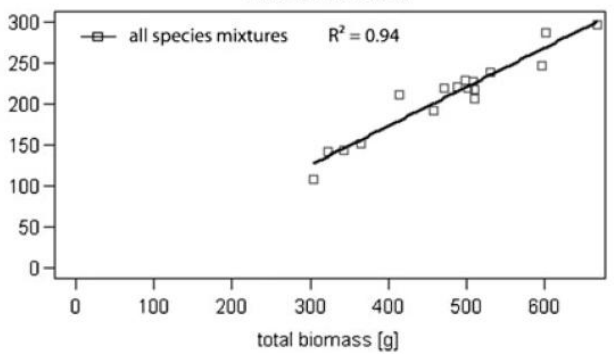

simplification $(P<0.05$ for backward steps) from linear models with interaction of species mixture as the experimental factor (root biomass= factor + total biomass + factor $\times$ total biomass). Only significant regression lines are shown to simplify the figure

(Fig. 1). Besides, the mean relative increment in diameter was highest for P. serotina, whereas $R$. pseudoacacia had the highest mean increment in height (Table 1). Based on the significantly higher growth rates of the two exotic species, the mixture with one of these species resulted in a substantial biomass reduction and altered biomass partitioning of native

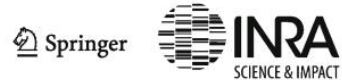


Q. robur and C. betulus (Table 2). Furthermore, our results showed that root competition (RC treatment) had an additional negative effect on the biomass production of both native species (Fig. 2 and Table 2). In the RC treatment, R. pseudoacacia and $P$. serotina occupied most of the available rooting capacity of the pot in mixtures of native and exotic species. By occupying the rooting space that theoretically "belongs" to the less competitive native species, the exotic species most likely had access to additional resources, whereas the resource availability for $Q$. robur and $C$. betulus was restricted.

The high competitiveness and predominance of $R$. pseudoacacia and P. serotina in the pot experiment could be explained by their life history traits. Both exotic species are typical early successional species characterized by a rapid growth rate under open field conditions, especially in the seedling stage like in our study (e.g., von Holle et al. 2006; Closset-Kopp et al. 2007). The ability to rapidly deplete a resource turns the exotic species of this study into successful competitors that suppress co-occurring species (e.g., Motta et al. 2009; Closset-Kopp et al. 2011).

\subsection{Allocation to root biomass as a sign for competitive stress}

One of the most important factors determining the belowground competitiveness of plants is the occupation of soil space (Casper and Jackson 1997). In the pot experiment, both native species in our experiment allocated relatively more biomass to the roots when growing together with one of the exotic species in the RC treatment (Fig. 2, RC, and Table 3). The exotic species had a significantly higher absolute root biomass than $Q$. robur and C. betulus, and correspondingly, they were most likely able to take up a higher amount of nutrients. This could have led to a nutrient deficiency for the co-occurring native species. Hence, the shift in biomass allocation of $Q$. robur and C. betulus toward a higher proportion of root biomass could be a reaction to limited belowground resource availability, as suggested in the balanced growth hypothesis (Shipley and Meziane 2002). The higher proportion of root biomass of the two native species was achieved at the expense of reduced leaf and branch biomass (Table 3). The interaction of water transport and photosynthesis supports the greater investment into roots. Dry conditions do not only favor

Table 3 Effects of the factors "competition treatments" and "species mixtures" on allocation to the different biomass compartments (in percent)

\begin{tabular}{|c|c|c|c|c|c|c|c|c|c|c|c|}
\hline \multirow[t]{2}{*}{ Species } & \multirow[t]{2}{*}{$\begin{array}{l}\text { Biomass } \\
\text { compartment }\end{array}$} & \multicolumn{3}{|c|}{$\begin{array}{l}\text { Competition } \\
\text { treatment }\end{array}$} & \multirow{2}{*}{ 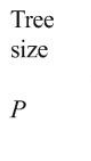 } & \multicolumn{5}{|c|}{ Mixed with } & \multirow{2}{*}{ 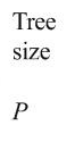 } \\
\hline & & $\mathrm{RC}$ & $\mathrm{nRC}$ & $P$ & & $\begin{array}{l}\text { Quercus } \\
\text { robur }\end{array}$ & $\begin{array}{l}\text { Carpinus } \\
\text { betulus }\end{array}$ & $\begin{array}{l}\text { Robinia } \\
\text { pseudoacacia }\end{array}$ & $\begin{array}{l}\text { Prumus } \\
\text { serotina }\end{array}$ & $P$ & \\
\hline \multirow[t]{5}{*}{ Quercus robur } & Belowground & $54^{\mathrm{a}}$ & $52^{\mathrm{a}}$ & 0.219 & $<0.001$ & $49^{a}$ & $49^{a}$ & $62^{b}$ & $57^{\mathrm{b}}$ & $<0.001$ & 0.137 \\
\hline & Aboveground & $46^{a}$ & $48^{a}$ & 0.216 & 0.011 & $51^{\mathrm{a}}$ & $51^{a}$ & $38^{\mathrm{b}}$ & $43^{b}$ & $<0.001$ & 0.068 \\
\hline & Stem & $22^{a}$ & $23^{a}$ & 0.715 & 0.821 & $23^{\mathrm{a}}$ & $23^{a}$ & $19^{\mathrm{a}}$ & $25^{\mathrm{a}}$ & 0.146 & 0.405 \\
\hline & Branch & $7^{a}$ & $8^{a}$ & 0.257 & $<0.001$ & $9^{a}$ & $9^{a}$ & $4^{b}$ & $6^{\mathrm{ab}}$ & $<0.001$ & 0.364 \\
\hline & Leaf & $17^{\mathrm{a}}$ & $17^{\mathrm{a}}$ & 0.444 & 0.019 & $19^{\mathrm{a}}$ & $19^{a}$ & $15^{b}$ & $12^{b}$ & $<0.001$ & 0.075 \\
\hline \multirow[t]{5}{*}{ Carpinus betulus } & Belowground & $39^{a}$ & $39^{b}$ & 0.032 & $<0.001$ & $37^{\mathrm{ab}}$ & $35^{\mathrm{a}}$ & $42^{\mathrm{ab}}$ & $45^{b}$ & 0.018 & 0.002 \\
\hline & Aboveground & $61^{a}$ & $61^{\mathrm{b}}$ & 0.032 & $<0.001$ & $63^{a b}$ & $65^{a}$ & $58^{\mathrm{ab}}$ & $55^{\mathrm{b}}$ & 0.018 & 0.002 \\
\hline & Stem & $28^{a}$ & $25^{b}$ & 0.007 & 0.201 & $27^{\mathrm{a}}$ & $27^{a}$ & $28^{\mathrm{a}}$ & $25^{\mathrm{a}}$ & 0.338 & 0.273 \\
\hline & Branch & $13^{a}$ & $15^{\mathrm{a}}$ & 0.890 & $<0.001$ & $15^{\mathrm{a}}$ & $16^{\mathrm{a}}$ & $11^{\mathrm{a}}$ & $13^{a}$ & 0.175 & $<0.001$ \\
\hline & Leaf & $20^{a}$ & $21^{\mathrm{a}}$ & 0.914 & 0.030 & $21^{\mathrm{ab}}$ & $22^{a}$ & $19^{\mathrm{bc}}$ & $17^{\mathrm{c}}$ & 0.023 & 0.828 \\
\hline \multirow{5}{*}{$\begin{array}{l}\text { Robinia } \\
\quad \text { pseudoacacia }\end{array}$} & Belowground & $30^{\mathrm{a}}$ & $31^{\mathrm{a}}$ & 0.946 & 0.434 & $30^{\mathrm{ab}}$ & $30^{\mathrm{ab}}$ & $29^{a}$ & $32^{b}$ & 0.017 & 0.588 \\
\hline & Aboveground & $70^{a}$ & $69^{a}$ & 0.949 & 0.356 & $68^{a}$ & $70^{\mathrm{ab}}$ & $72^{b}$ & $68^{a}$ & 0.050 & 0.929 \\
\hline & Stem & $30^{a}$ & $30^{\mathrm{a}}$ & 0.616 & 0.495 & $30^{\mathrm{ab}}$ & $29^{a b}$ & $32^{\mathrm{a}}$ & $28^{b}$ & 0.040 & 0.215 \\
\hline & Branch & $16^{a}$ & $16^{\mathrm{a}}$ & 0.649 & 0.520 & $17^{\mathrm{a}}$ & $18^{a}$ & $15^{\mathrm{a}}$ & $15^{\mathrm{a}}$ & 0.104 & 0.483 \\
\hline & Leaf & $24^{a}$ & $23^{a}$ & 0.892 & 0.087 & $20^{\mathrm{a}}$ & $23^{a}$ & $25^{\mathrm{a}}$ & $25^{a}$ & 0.070 & 0.944 \\
\hline \multirow[t]{5}{*}{ Prunus serotina } & Belowground & $40^{\mathrm{a}}$ & $44^{b}$ & 0.004 & 0.746 & $40^{\mathrm{a}}$ & $40^{\mathrm{a}}$ & $40^{\mathrm{a}}$ & $45^{b}$ & 0.050 & 0.812 \\
\hline & Aboveground & $60^{a}$ & $56^{\mathrm{b}}$ & 0.004 & 0.746 & $60^{a}$ & $60^{\mathrm{a}}$ & $60^{\mathrm{a}}$ & $55^{\mathrm{b}}$ & 0.050 & 0.812 \\
\hline & Stem & $22^{a}$ & $22^{\mathrm{a}}$ & 0.162 & 0.091 & $22^{a}$ & $21^{\mathrm{a}}$ & $21^{\mathrm{a}}$ & $22^{\mathrm{a}}$ & 0.483 & 0.190 \\
\hline & Branch & $16^{\mathrm{a}}$ & $14^{\mathrm{b}}$ & 0.039 & $<0.001$ & $17^{\mathrm{a}}$ & $17^{\mathrm{a}}$ & $14^{\mathrm{a}}$ & $15^{\mathrm{a}}$ & 0.566 & 0.107 \\
\hline & Leaf & $22^{a}$ & $20^{\mathrm{a}}$ & 0.112 & 0.082 & $21^{\mathrm{ab}}$ & $22^{a b}$ & $25^{\mathrm{a}}$ & $18^{b}$ & $<0.001$ & 0.841 \\
\hline
\end{tabular}

Data are averaged for each species per pot. We adjusted for the effect of tree size as reflected by diameter in the ANCOVA model $\left(b_{i o m a s s}=\right.$ factor $_{a, b}+$ tree size). The proportions of biomass compartments are referenced to the average seedling diameter per species. Significant factors and tree size are indicated by $P$ values. Different lowercase letters indicate significant differences between both competition treatments and the different species mixtures (Tukey's test: $P<0.05$ ) 
a reduction in leaf biomass to lower the transpiration rate but simultaneously lead to an increase in root biomass to absorb a higher amount of water (McCarthy and Enquist 2007; Schall et al. 2012). Oliver and Larson (1990) asserted that the allocation of photosynthates to the different biomass compartments proceeds in an order of priorities related to the competitive situation of a tree. In the case of root competition, a greater allocation to the roots is achieved at the expense of a reduced allocation to the leaves and/or the stem (Coomes and Grubb 2000; Murphy and Dudley 2007; Closset-Kopp et al. 2011). That way, plants are able to create a balance between carbon fixation by leaves and nutrient and/or water acquisition by roots (Shipley and Meziane 2002).

In contrast to the native species, the response of the exotic species to belowground competition was less distinct due to their stronger competitiveness. Nevertheless, $R$. pseudoacacia allocated more biomass to the roots when growing together with the competitive $P$. serotina. These findings may be explained by the second way plants respond to environmental stress, as suggested by the balanced growth hypothesis: not just allocating biomass to the organs acquiring the most limiting resource but increasing uptake efficiency. Actually, the finding that $P$. serotina in monoculture and in mixture and $R$. pseudoacacia in monoculture, though exposed to high competition, had not started changing biomass allocation pattern yet suggests improved resource uptake efficiency. This hypothesis should be investigated in a future experiment. It seems as if the competition by the neighboring plants was not yet strong enough in these mixture types to already initiate changes in biomass allocation.

4.3 Implications for future work on the invasiveness of exotic tree species

In order to test the in situ and long-term success of the four species of this study, a factorial experiment, e. g., by exposing planted seedlings in pure and mixed groups to a gradient of canopy openings and/or different soil moisture levels (for instance by trenching), would be needed. However, some beneficial traits of early successional pioneer species are achieved at the expense of other plant attributes (Martin et al. 2010), which might be important under natural conditions. In the Ticino valley for example, flooding occurs quite frequently. In another experiment where we exposed $Q$. robur and $P$. serotina seedlings to flooding and drought and analyzed volatile organic compound emissions, we found that $Q$. robur seedlings appeared to tolerate flood much better than $P$. serotina seedlings (Bourtsoukidis et al. 2013). However, the high tolerance of $Q$. robur seedlings to alterations in soil moisture will only lead to a competitive advantage if light availability is high enough not only to survive but to grow, which may not always be the case under a dense canopy of the exotic species. In contrast to $Q$. robur, C. betulus seedlings, a shade-tolerant species, might be competitive enough to successfully grow in the canopy of the two exotic species.

Acknowledgments We are grateful to K.-H. Heine, A. Parth, M. Unger, T. Waldmann, and U. Westphal and to all other helpers who were a big support while collecting the data.

Funding We would like to thank the Marianne and Dr. Fritz-Walter Fischer Foundation within the Stifterverband für die Deutsche Wissenschaft for funding our research and the DAAD (German Academic Exchange Service) VIGONI program for supporting project-based exchange.

\section{References}

Aerts R, Boot R, van der Aart P (1991) The relation between above- and belowground biomass allocation patterns and competitive ability. Oecologia 87:551-559

Ammer C (2003) Growth and biomass partitioning of Fagus sylvatica L. and Quercus robur L. seedlings in response to shading and small changes in the R/FR-ratio of radiation. Ann For Sci 60:163-171

Annighöfer P, Mölder I, Zerbe S, Kawaletz H, Terwei A, Ammer C (2012) Biomass functions for the two alien tree species Prunus serotina Ehrh. and Robinia pseudoacacia L. in floodplain forests of Northern Italy. Eur J For Res 131:1619-1635

Bloor J, Leadley P, Barthes L (2008) Responses of Fraxinus excelsior seedlings to grass-induced above- and below-ground competition Plant Ecol 194:293-304

Bourtsoukidis E, Kawaletz H, Radacki D, Schütz S, Hakola H, Hellén H, Noe S, Mölder I, Ammer C, Bonn B (2013) Impact of flooding and drought conditions on the emission of volatile organic compounds of Quercus robur and Prunus serotina. Trees. doi:10.1007/s00468013-0942-5

Cahill JF (2003) Lack of relationship between below-ground competition and allocation to roots in 10 grassland species. J Ecol 91:532-540

Casper BB, Jackson RB (1997) Plant competition underground. Annu Rev Ecol Syst 28:545-570

Closset-Kopp D, Chabrerie O, Valentin B, Delachapelle H, Decocq G (2007) When Oskar meets Alice: does a lack of trade-off in $\mathrm{r} / \mathrm{K}$ strategies make Prunus serotina a successful invader of European forests? For Ecol Manag 247:120-130

Closset-Kopp D, Saguez R, Decocq G (2011) Differential growth patterns and fitness may explain contrasted performances of the invasive Prunus serotina in its exotic range. Biol Invasions 13:1341-1355

Coomes DA, Grubb PJ (2000) Impacts of root competition in forests and woodlands: a theoretical framework and review of experiments. Ecol Monogr 70:171-207

Crawley MJ (2007) The R book. Wiley, Chichester

Curt T, Coll L, Prevosto B, Balandier P, Kunstler G (2005) Plasticity in growth, biomass allocation and root morphology in beech seedlings as induced by irradiance and herbaceous competition. Ann For Sci 62:51-60

DAISIE Project (2009) Handbook of alien species in Europe. Springer, New York, 399 pp

Delagrange S, Messier C, Lechowicz MJ, Dizengremel P (2004) Physiological, morphological and allocational plasticity in understory deciduous trees: importance of plant size and light availability. Tree Physiol 24:775-784

Donald C (1958) The interaction of competition for light and for nutrients. Aust J Agric Res 9:421-435

Ellenberg H (1988) Vegetation ecology of Central Europe, 4th edn. Cambridge University Press, Cambridge

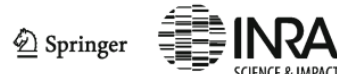


Feng Y, Wang J, Sang W (2007) Biomass allocation, morphology and photosynthesis of invasive and noninvasive exotic species grown at four irradiance levels. Acta Oecol 31:40-47

Goldberg DE (1990) Components of resource competition in plant communities. In: Grace JB, Tilman D (eds) Perspectives on plant competition. Academic, San Diego, pp 27-49

Haase JU (2009) Biodiversity and ecosystem functioning: the effects of tree and litter diversity. Dissertation, University of Zurich

Hofmann R, Ammer C (2008) Biomass partitioning of beech seedlings under the canopy of spruce. Austrian J For Sci 125:51-66

Horn HS (1971) The adaptive geometry of trees. Princeton University Press, Princeton

Ibrahim L, Proe MF, Cameron AD (1998) Interactive effects of nitrogen and water availabilities on gas exchange and whole-plant carbon allocation in poplar. Tree Physiol 18:481-487

Kawaletz H, Mölder I, Zerbe S, Annighöfer P, Terwei A, Ammer C (2013) Exotic tree seedlings are much more competitive than natives but show underyielding when growing together. J Plant Ecol 6:305-315

Kleczewski NM, Herms DA, Bonello P (2012) Nutrient and water availability alter belowground patterns of biomass allocation, carbon partitioning, and ectomycorrhizal abundance in Betula nigra. TreesStruct Funct 26:525-533

Kleinbauer I, Dullinger S, Peterseil J, Essl F (2010) Climate change might drive the invasive tree Robinia pseudoacacia into nature reserves and endangered habitats. Biol Conserv 143:382-390

Lamarque LJ, Delzon S, Lortie CJ (2011) Tree invasions: a comparative test of the dominant hypotheses and functional traits. Biol Invasions 13:1969-1989

Lorimer CG (1983) Tests of age-independent competition indices for individual trees in natural hardwood stands. For Ecol Manag 6: 343-360

Mack R, Simberloff D, Lonsdale W, Evans H, Clout M, Bazzaz FA (2000) Biotic invasions: causes, epidemiology, global consequences, and control. Ecol Appl 10:689-710

Martin PH, Canham CD, Kobe RK (2010) Divergence from the growthsurvival trade-off and extreme high growth rates drive patterns of exotic tree invasions in closed-canopy forests. J Ecol 98:778-789

McCarthy MC, Enquist BJ (2007) Consistency between an allometric approach and optimal partitioning theory in global patterns of plant biomass allocation. Funct Ecol 21:713-720

McPhee CS, Aarssen LW (2001) The separation of above- and belowground competition in plants a review and critique of methodology. Plant Ecol 152:119-136

Morrison JA, Mauck K (2007) Experimental field comparison of native and non-native maple seedlings: natural enemies, ecophysiology, growth and survival. J Ecol 95:1036-1049

Motta R, Nola P, Berretti R (2009) The rise and fall of the black locust (Robinia pseudoacacia L.) in the "Siro Negri" Forest Reserve
(Lombardy, Italy): lessons learned and future uncertainties. Ann For Sci $66: 410-410$

Murphy GP, Dudley SA (2007) Above- and below-ground competition cues elicit independent responses. J Ecol 95:261-272

Nilsson U, Albrektson A (1993) Productivity of needles and allocation of growth in young Scots pine trees of different competitive status. For Ecol Manag 62:173-187

Oliver CD, Larson BC (1990) Forest stand dynamics. McGraw-Hill, New York

Pyšek P, Richardson DM (2008) Traits associated with invasiveness in alien plants: where do we stand? Biol Invasions 193:97-125

R Development Core Team (2012) R: a language and environment for statistical computing. R Foundation for Statistical Computing, Vienna, Austria

Rice S, Westerman B, Federici R (2004) Impacts of the exotic, nitrogenfixing black locust (Robinia pseudoacacia) on nitrogen-cycling in a pine-oak ecosystem. Plant Ecol 174:97-107

Schall P, Lödige C, Beck M, Ammer C (2012) Biomass allocation to roots and shoots is more sensitive to shade and drought in European beech than in Norway spruce seedlings. For Ecol Manag 266:246-253

Shipley B, Meziane D (2002) The balanced-growth hypothesis and the allometry of leaf and root biomass allocation. Funct Eco $16: 326-331$

Starfinger U, Kowarik I, Rode M, Schepker H (2003) From desirable ornamental plant to pest to accepted addition to the flora?-The perception of an alien tree species through the centuries. Biol Invasions 5:323-335

Terwei A, Zerbe S, Zeileis A, Mölder I, Annighöfer P, Kawaletz H, Ammer C (2013) Which are the factors controlling tree seedling establishment in North Italian floodplain forests invaded by nonnative tree species? For Ecol Manag 304:192-203

van Hees AFM (1997) Growth and morphology of pedunculate oak (Quercus robur L.) and beech (Fagus sylvatica L.) seedlings in relation to shading and drought. Ann For Sci 54:9-18

Vanhellemont M, Wauters L, Baeten L, Bijlsma RJ, De Frenne P, Hermy M, Verheyen K (2010) Prunus serotina unleashed: invader dominance after 70 years of forest development. Bio Invasions 12:1113-1124

von Holle B, Joseph KA, Largay EF, Lohnes RG (2006) Facilitation between the introduced nitrogen-fixing tree, Robinia pseudoacacia, and nonnative plant species in the glacial outwash upland ecosystem of Cape Cod, MA. Biodivers Conserv 15:2197-2215

Weiner J (2004) Allocation, plasticity and allometry in plants. Perspect Plant Ecol 6:207-215

Wetterstation Göttingen (2013) http://www.wetterstation-goettingen.de/ Accessed 29 January 2013

Wilson JB (1988) Shoot competition and root competition. J Appl Ecol 25:279-296 
Chapter

Synthesis 


\section{Methodological discussion of the pot experiment}

In a previous literature review, numerous pot experiments with tree species were analyzed to gain helpful information on the correct implementation of the present study (chapter 2). Based on this knowledge, I decided to use already established plants to avoid high seedling mortality by selfculture. The one-year-old nursery grown tree seedlings were similar in size and grew up under equal conditions. To study the competition between the tree species and individuals in more detail, above- and belowground interactions were investigated separatelty by using a modified 'divided pot technique' (e.g., Donald 1958; McPhee and Aarssen 2001). For this technique, vertical partitions were installed that divide root and shoot competition within the pots. All species mixtures were randomly attributed to one of the following competition treatments: no competition (NC1, NC4), shoot competition (SC), root competition (RC), and full competition (FC). The experimental set-up is further described in chapter 1.

In the NC4 treatment, in which the four plants were completely separated by above- and belowground partitions, mortality rate for all species was highest compared to the other treatments. Therefore, neither the data of the NC4 treatment nor of the NC1 treatment as comparative values were used for the analyses. Significant differences in light availability were not considered to be the reason for the high mortality. White partition sheets and diffuse sky radiation leveled the light conditions on all four sections of the pot. However, transpiration rate could be different for the plants within one pot: In consequence of the aboveground partitions, some plants were more affected by direct sunlight than others and, thus, may have a higher transpiration rate. For following studies, frequently rotation of all pots should be considered. By reasons of the high number of pots, this method was not practicable in the present experiment. Although all plants were watered regularly with the same amount of water, differences in soil water content could possibly influence plant survival. Due to aboveground partitions, the four pot compartments were not equally saturated with rain water. Due to belowground partitions, water was not evenly distributed in the pot. To ensure homogeneous soil water content after rainfall, a special porous membrane could be used allowing nutrients and water to pass but preventing root passage in adjacent pot compartments (McPhee and Aarssen 2001).

Unexpectedly, shoot competition had no significant effect on tree growth in the pot experiment.

Plants often showed lateral shoot growth across the rim of the pot in order either to compensate the restricted aboveground space due to partitions or to prevent shoot intermingling and competition in pots without aboveground partitions. Donald (1958) avoided the problem of lateral growth of grass species by installing a cylinder around the pot that enclosed the whole plant and limited its expansion on the pot's area. However, the installation of outer cylinders 
could affect plant growth by inhibiting airflow and altering light quality and quantity (McPhee and Aarssen 2001). Thus, by creating an unrealistic environment, the installation of cylinders does not demonstrate an ideal solution to study the effect of shoot competition.

The high growth increment of both exotic species could be another reason, why the exclusion of aboveground competition did not work: Mean seedling height at the end of the study was $146.40 \mathrm{~cm}$ for R. pseudoacacia and $136.08 \mathrm{~cm}$ for P. serotina, i.e. both species managed to overtop the partitions that had a height of $1 \mathrm{~m}$. The high dimensions of tree species - even of tree seedlings - cause problems when measuring aboveground (and belowground) competition. For gaining significant results in following studies, either higher partitions to fully prevent plant interactions aboveground or studying younger seedlings should be considered. Mesh partitions would prevent tree seedlings from growing together but would not prevent from shading each other. Another possible method to avoid shoot competition between herbaceous plants is to tie back the aboveground neighboring vegetation (e.g., Cahill 1999; Rajaniemi et al. 2003; Lamb et al. 2009). There is no evidence that this method affects the belowground competitiveness of neighboring roots. However, tying back the aboveground parts of competing plants would probably damage the tree bark and, thus, is not an appropriate method for tree species except for very young seedlings without woody stems.

Not only shoot growth but also root growth of R. pseudoacacia and P. serotina was higher than expected. Belowground partitions seemed to allow slight root competition since the total biomass of native seedlings mixed with one of the exotic species was lower than in monocultures even in the $\mathrm{nRC}$ treatment. Thus, the installed belowground partitions did not succeed in fully preventing root competition since both exotic species occupied the whole rooting volume and even grew in the narrow space between pot and partition. For completely isolating the pot compartments, a water-resistant silicone sealing could be applied. A bigger pot size could have improved the separation of the plants in the sections by providing a higher amount of available resources and the exotic species would have had no need to expand in the neighboring root compartment. In larger pots, though, plants would have no need to compete for a longer time and therefore longterm studies would be necessary to get visible results. However, if the two treatments in which the tree seedlings were exposed to root competition (i.e. RC and FC) are pooled and compared with the treatment excluding root competition (i.e. SC), a significant influence of root competition can be found. In all data analyses, I therefore contrasted 'root competition' (RC) with 'no root competition' (nRC).

Despite these deficits, the pot experiment revealed important results regarding the influence of root competition on biomass production and biomass allocation: The study demonstrated that the growth of the less competitive native tree seedlings was additionally affected by the root 
competition of superior exotic species. This finding would have been difficult to detect under field conditions, where destructive harvests are less applicable. Possibly, effects of shoot competition on tree growth could be underestimated due to the deficient aboveground partitions. This factor should be further investigated in future studies.

\section{Competitive advantages of $\boldsymbol{P}$. serotina and $\boldsymbol{R}$. pseudoacacia}

Several studies tried to explain which factors determine the competitiveness of plants under different environmental conditions. Following Grime (1977) and Tilman (1982), plants are successful competitors by maximizing the resource uptake and, thus, rapidly depleting a resource. Goldberg (1990) broadened this idea and stated that plants can be superior competitors either by the ability to rapidly reduce resource availability, or by the ability to continue growth under low resource levels. This concept characterized the competitiveness of plant species either by the suppressive strength of one species on another, or by the extent to which a species is influenced by the presence of competitors. Another current approach - developed for exotic plant invaders - is based on the phenotypic plasticity as a reason for high competitiveness and, thus, a successful plant invasion (Richards et al. 2006). Due to phenotypic plasticity, a plant invader could either be (1) a 'Jack-of-all-trades' species, having the ability to maintain fitness under unfavorable conditions, (2) a 'Master-of-some' species, with the ability to enhance fitness under favorable conditions, or (3) a 'Jack-and-master' species, by combining elements of (1) and (2).

Referring to the species of this study, the seedlings of Q. robur and C. betulus obviously were the less competitive species in mixtures with the exotic species. After Goldberg (1990), both species had a low competitiveness since they did not suppress the growth of the admixed species but, in contrast, were strongly affected by the presence of the exotic competitors. According to the concept of Richards et al. (2006), seedlings of R. pseudoacacia and P. serotina can be characterized as a 'Jack-and-master' species based on the ability to increase fitness and rapidly spread in favorable environments on the one hand and to maintain fitness even under unfavorable conditions. R. pseudoacacia is a light demanding pioneer species that has a high competitiveness in early successional stages (Huntley 1990). Under adequate light conditions, it grows rapidly on appropriate sites and, furthermore, occurs on poor soils due to its ability to fix nitrogen. Juvenile P. serotina is known for its 'sit-and-wait' strategy ('Oskar syndrome') meaning that it is able to survive under shady conditions and to grow rapidly when light conditions improve (ClossetKopp et al. 2007). Both the abilities to rapidly deplete a resource and to continue growth under inappropriate conditions turn R. psendoacacia and P. serotina into successful competitors that suppress co-occurring species and are just slightly influenced by the presence of other 
competitors (Sabo 2000; Pairon et al. 2006; Closset-Kopp et al. 2007; Motta et al. 2009; ClossetKopp et al. 2011).

Among other biological traits, a considerably faster growth rate and higher biomass production are regarded as a main reason for the predominance of plant invaders (e.g., Rejmánek and Richardson 1996; Alpert et al. 2000; Pyšek et al. 2009). In the pot experiment, both exotic species showed a significantly higher biomass production resulting in a strong suppression of Q. robur and C. betulus (chapter 3). Mean plant biomass of both native species decreased significantly when they were admixed to one of the non-native species. Additionally, growth and biomass production of $Q$. robur and C. betulus were reduced further when exposed to belowground competition by the exotics. I found most of the available rooting volume in the pot being occupied by one of the exotic species. By occupying the rooting space of the native species, P. serotina and R. pseudoacacia received supplemental resources, while the rooting capacity, i.e. the access to available water and nutrients, for $Q$. robur and $C$. betulus was strongly restricted (Aerts et al. 1991; Robinson et al. 1999). In contrast to P. serotina and R. psendoacacia, which are known to have an extensively spreading root system (Huntley 1990; Marquis 1990), Q. robur and C. betulus have a low competitive ability belowground (Rewald and Leuschner 2009). The data showed that the inferior, i.e. less competitive, native species managed to increase their biomass production when superior root competition was excluded by partitions in the pot. Thus, even a spatially restricted rooting volume seemed to provide better growing conditions than direct root competition by an exotic invasive species.

Furthermore, under strong belowground competition, inferior native species allocated a higher proportion of biomass to the roots (chapter 4). This is in accordance with the 'balanced-growth hypothesis' (Shipley and Meziane 2002) stating that plants have to allocate biomass preferentially to the roots in case of belowground competition to increase the capture of limiting water and nutrients. A greater allocation to the roots is achieved at the expense of a reduced biomass allocation to aboveground compartments (Coomes and Grubb 2000). Not only the native but also the non-native species of the study showed plasticity in biomass allocation to compensate limited resources in case of interaction with strong competitors (Claridge and Franklin 2002). For invasive species, adaptive plasticity is an important attribute to successfully establish in new regions and to outcompete the native vegetation (Davidson et al. 2011). Van Kleunen et al. (2010) confirmed the positive correlation between different biological traits such as biomass allocation, growth rate, and invasiveness.

Apart from a higher biomass production and plasticity in biomass allocation, other competition mechanisms were found to favor the strong competitiveness of exotic plant invaders. I could observe an earlier leaf development of both exotic species compared to the native trees (Figure 
2A). Approximately $90 \%$ of the leaves of $P$. serotina already appeared in the second half of March 2011, i.e. two weeks before leaf flushing of R. psendoacacia and four weeks earlier in comparison to both native species. In the literature, early flowering of shade intolerant $P$. serotina is regarded as a possibility to utilize full light availability. In general, $P$. serotina takes advantage of the absent overstory canopy and develops its leaves in early spring (Godefroid et al. 2005). That way, seedlings of $P$. serotina are able to persist even under shady conditions for several years (Horsley and Gottschalk 1993). Leaf coloring and subsequent leaf fall of the exotic species differed as well from the native species. It began relatively early for $R$. psendoacacia, but was latest for P. serotina (Figure 2B). Based on its early leaf flushing and the late leaf fall, P. serotina could extend its individual growing period by several weeks compared to Q. robur and C. betulus. Early and extensive flowering and fructification is regarded as another important trait of invasive exotic species (Williamson and Fitter 1996; Pyšek and Richardson 2007). Early seed production is confirmed by the literature for both species: After Huntley (1990), R. psendoacacia starts flowering at the age of six and P. serotina at the age of six (Marquis 1990) or ten (Kowarik 2010). In the pot experiment, seedlings of P. serotina and R. psendoacacia started flowering and seed production already at the age of three.

A

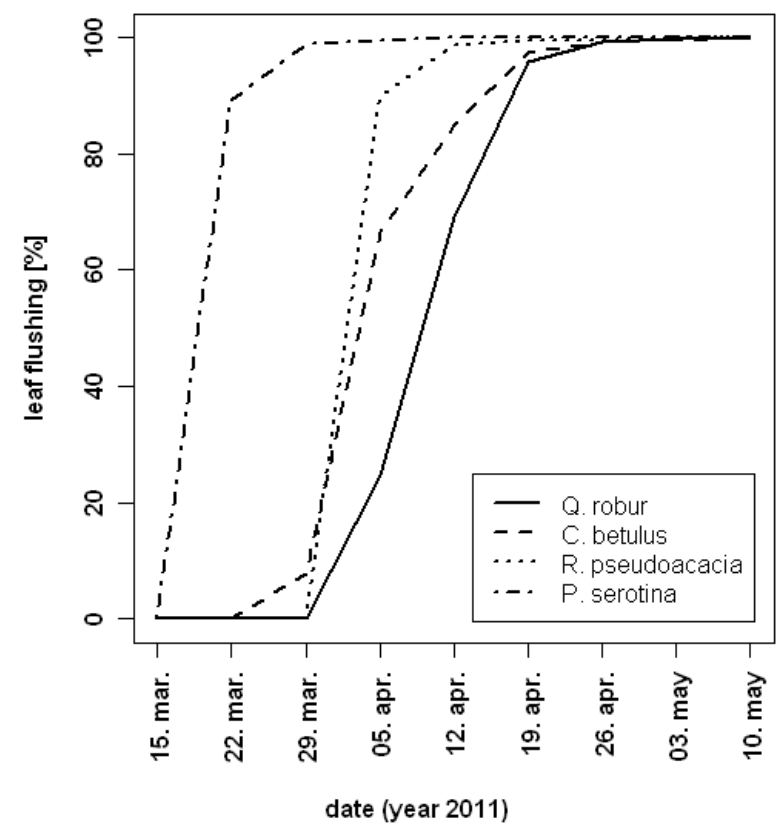

B

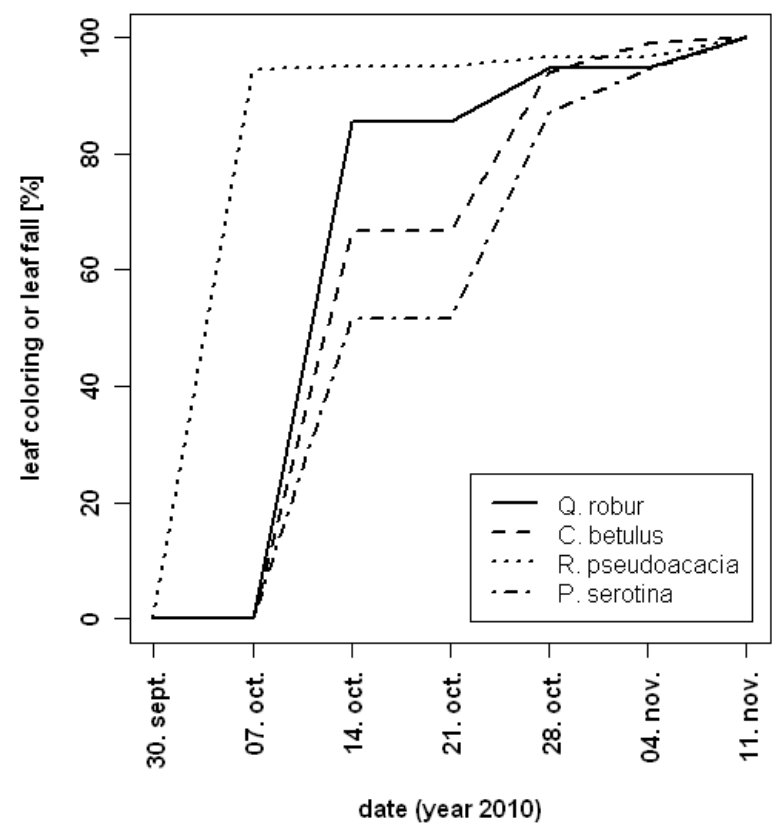

Figure 2 (A) Leaf flushing in spring 2011 and (B) leaf coloring or leaf fall in autumn 2010 of the four tree species. Leaf flushing in 2010 is biased due to the planting impact and, thus, shows slightly divergent results. 


\section{Stress tolerance of $\boldsymbol{P}$. serotina and $\boldsymbol{R}$. pseudoacacia}

A lot of plant invaders such as $P$. serotina and $R$. psendoacacia mainly occur in early successional stages subsequent to disturbances and show typical attributes of pioneer species, i.e. rapid growth and dispersal (Abrams and Mostoller 1995; Rice et al. 2004; von Holle et al. 2006; Closset-Kopp et al. 2007). However, the presence of exotic plants often depends on periodic disturbances, i.e. absent disturbances lead to a decreasing abundance or even extinction of many non-native species (Closset-Kopp et al. 2007). There is evidence that the traits of early successional pioneer species are achieved at the expense of other plant attributes, e.g., shade tolerance, which are important to become predominant in later seral stages (Martin et al. 2010). Accordingly, the results indicated that exotic species may have a generally higher sensitivity to environmental stress. In the pot experiment, P. serotina and R. pseudoacacia showed a higher mortality rate compared to both native species due to not further defined factors. There were neither significant differences between both competition treatments RC and $\mathrm{nRC}$ (data not shown) nor between the species mixtures with the exception of P. serotina in the RC treatment (Table 2). Averaged for all competition treatments and species mixtures, mortality rate was highest for P. serotina (45\%), $24 \%$ for R. pseudoacacia, $13 \%$ for $Q$. robur, and lowest for C. betulus $(10 \%)\left(P<0.001, \chi^{2}\right.$-test). Thus, both exotic species seemed to have a lower tolerance to environmental changes after transplanting such as the irrigation system, the light availability in the experiment, herbivore attacks, or other factors.

Table 2 Mortality rate [\%] of all tree species in the different mixtures with (RC) or without (nRC) the influence of root competition. $P$-values indicate significant differences between the species mixtures in the RC and nRC treatment $\left(\chi^{2}\right.$-test, two-sided, $* P<0.05$, ** $P<0.01$, *** $\left.P<0.001\right)$.

\begin{tabular}{|c|c|c|c|c|c|c|}
\hline \multirow{2}{*}{ species } & & \multirow{2}{*}{$\begin{array}{l}\text { mixed with } \\
\text { Q. robur }\end{array}$} & & & \multirow[b]{2}{*}{ P. serotina } & \multirow[b]{2}{*}{$P$} \\
\hline & & & C. betulus & R. pseudoacacia & & \\
\hline \multirow{2}{*}{ Q. robur } & $\mathrm{RC}$ & 6.25 & 12.50 & 17.50 & 15.00 & 0.126 \\
\hline & $\mathrm{nRC}$ & 16.67 & 10.00 & 7.50 & 17.50 & 0.448 \\
\hline \multirow{2}{*}{ C. betulus } & $\mathrm{RC}$ & 8.75 & 14.58 & 7.50 & 10.00 & 0.429 \\
\hline & $\mathrm{nRC}$ & 5.00 & 4.17 & 17.50 & 15.00 & 0.091 \\
\hline \multirow{2}{*}{ R. pseudoacacia } & $\mathrm{RC}$ & 25.00 & 21.25 & 34.38 & 25.00 & 0.228 \\
\hline & $\mathrm{nRC}$ & 10.00 & 20.00 & 16.67 & 32.50 & 0.078 \\
\hline \multirow{2}{*}{ P. serotina } & $\mathrm{RC}$ & 41.25 & 37.50 & 37.50 & 60.42 & 0.004 ** \\
\hline & $\mathrm{nRC}$ & 45.00 & 60.00 & 30.00 & 43.75 & 0.063 \\
\hline
\end{tabular}

While R. pseudoacacia is well adapted to drought conditions (Sabo 2000; Grünewald et al. 2009; Rédei et al. 2012), P. serotina is described as intolerant to drought (Juhász et al. 2009) and to waterlogging (Closset-Kopp et al. 2011). On sites deviating from the optimal range, P. serotina is 
not able to provide enough energy for a rapid height growth and fructification (Closset-Kopp et al. 2011). In the future, flood and drought events are expected to occur more frequently as a consequence of climate change (Lehner et al. 2006). Both environmental disturbances are typical abiotic stressors that affect physiology and growth of most terrestrial plant species (Kozlowski 1997; Glenz et al. 2006; Copolovici and Niinemets 2010; Loreto and Schnitzler 2010). To prevent further spreading of invasive species, knowledge on potential weaknesses of exotic species can be useful. Hall and Smith (1955) as well as Roloff et al. (1994) stated that P. serotina responds very sensitive to flooding and another study on black cherry showed decreasing production with increasing soil moisture (Marquis 1990). Accordingly, Brehm (2004) found water retention to be one of the most effective measures against P. serotina. In contrast, literature shows that co-occurring native species such as Q. robur would be most likely less negatively affected by anaerobic soil conditions (Dister 1981; Blom 1999; Kreuzwieser et al. 2004).

Against this background, the stress tolerance of 3-year-old seedlings of native Q. robur and invasive P. serotina to flooding and drought was tested in cooperation with the Institute for Atmospheric and Environmental Sciences/Aerosol and Environmental Research of the J. W. Goethe University in Frankfurt/Main (JProf. Dr. B. Bonn, E. Bourtsoukidis) and the Department of Forest Zoology and Forest Conservation of the Georg-August University in Göttingen (Prof. S. Schütz). Flood and drought can influence the primary and secondary metabolism of plants leading to changed emissions of volatile organic compounds (VOC) (Loreto and Schnitzler 2010). The emission of VOC can be used as an indicator for plant stress since type and amount of VOC can be altered by a great variety of stressors (e.g., Holzinger et al. 2000; Rottenberger et al. 2008; Jansen et al. 2009; Loreto and Schnitzler 2010). In a joint experiment, a novel cuvette enclosure approach was used to find differences in VOC emission of the two tree species depending on stress type and stress intensity. In a climate chamber - under controlled conditions - potted individuals of both species were exposed either to 'flood', 'drought', or 'control' treatments. The VOC emission rates were derived using proton-transferreaction mass spectrometry (PTR-MS) and gas chromatography-mass spectrometry (GC-MS) techniques. Additionally, chlorophyll fluorescence and $\mathrm{CO}_{2}$ uptake were measured for all tree seedlings. The hypothesis was tested that under stress conditions, Q. robur would have a competitive advantage over rather superior P. serotina due to its higher tolerance to flooding and drought. In the experiment, the emission of acetaldehyde along with a reduced chlorophyll fluorescence and $\mathrm{CO}_{2}$ uptake indicated a strong sensitivity of black cherry to water stress, whereas seedlings of pedunculate oak remained unaffected (Bourtsoukidis et al. 2013). Accordingly, P. serotina cannot be found in the frequently flooded parts of the hardwood 
floodplain forests of the biosphere reserve 'Valle del Ticino' (pers. comm. Annighöfer 2012). Drought stress similarly reduced VOC emission, chlorophyll fluorescence, and CO2 uptake of both species based on stomata closure to prevent excessive transpiration (Loewenstein and Pallardy 1998; Loreto and Schnitzler 2010). Nevertheless, Q. robur emitted a significantly higher amount of isoprene that serves as a thermo protective compound and, thus, will benefit plant performance under drought conditions (Sasaki et al. 2007). Hence, invasive P. serotina has a competitive advantage in intact environments due to its high growth rate and other biological traits. However, especially under flood conditions, native Q. robur seems to have an advantage over $P$. serotina. The high mortality rate of $P$. serotina in the pot experiment along with the reactions to flooding and drought conditions indicate a higher susceptibility to environmental stressors.

\section{Conclusions and outlook}

It was found that the native species $Q$. robur and $C$. betulus were much less competitive than the dominating R. psendoacacia and P. serotina - this result of the pot experiment corresponds with the situation in the biosphere reserve. The most important competition mechanism leading to the predominance of the exotic species was their significantly higher biomass production. It was evident that the native tree seedlings were clearly inferior - especially when they are exposed to root competition by the exotic species. Accordingly, Q. robur and C. betulus managed to increase their biomass production when root competition was excluded. Thus, not only aboveground competition but also root competition seems to play an important role for interacting native and exotic tree species. Mechanical control measures, i.e. felling of exotic individuals, reduce aboveground competition but do not necessarily affect root competition. Using its extensive and undamaged root system, P. serotina for instance, is able to develop numerous shoots by latent buds in the stump (Closset-Kopp et al. 2007). The resprouting ability of P. serotina seems to be promoted by felling (Annighöfer et al. 2012b). Thus, since most of the mechanical, chemical, and biological control measures do not show satisfying results, it could be more promising to keep natural succession unaffected with chance that the abundance of invasive species decreases gradually. The relatively high sensitivity to environmental stress (i.e. flooding, drought, shade) of some exotic species - indicated as well by the higher mortality rate in the pot experiment - could offer possibilities to control exotic tree invasions. High growth rates of most early successional invasive tree species are achieved at the expense of other traits such as shade tolerance, which are important to become predominant in later successional stages (Martin et al. 2010). Silvicultural 
management that allows natural succession could lead to a decreasing abundance of shade intolerant invasive species like P. serotina. Accordingly, Starfinger (1997) states that the dominance and abundance of black cherry is decreasing with proceeding succession.

In a revised experimental set-up further research could be done on the aboveground competition. Due to the described deficits, influence of shoot competition on tree growth could be underestimated. Besides, it would be worth investigating the competition effects under different light conditions. Q. robur, R. pseudoacacia, and P. serotina are all light demanding species. It would be an interesting question how competitiveness of each species would change under shade conditions. Further research could be also done on the stress tolerance of exotic species by conducting flood and drought treatments in a long-term experiment. The short-time experiment studying VOC emission revealed important results on the potential vulnerability of plant invaders.

\section{References}

Abrams M. D., Mostoller S. A. (1995): Gas exchange, leaf structure and nitrogen in contrasting successional tree species growing in open and understory sites during a drought. Tree Physiol 15: $361-370$.

Aerts R., Boot R., van der Aart P. (1991): The relation between above- and belowground biomass allocation patterns and competitive ability. Oecologia 87: 551-559.

Alpert P. (2006): The advantages and disadvantages of being introduced. Biol Invasions 8: $1523-1534$.

Alpert P., Bone E., Holzapfel C. (2000): Invasiveness, invasibility and the role of environmental stress in the spread of non-native plants. Perspect Plant Ecol Evol Syst 3: 52-66.

Annighöfer P., Schall P., Kawaletz H., Mölder I., Terwei A., Zerbe S., Ammer C. (2012b): Vegetative growth response of black cherry (Prunus serotina) to different mechanical control methods in a biosphere reserve. Can J For Res 42: 2037-2051.

Blom C. (1999): Adaptations to flooding stress: From plant community to molecule. Plant Biol 1: 261-273.

Bourtsoukidis E., Kawaletz H., Radacki D., Schütz S., Hakola H., Hellén H., Noe S., Mölder I., Ammer C., Bonn B. (2013): Impact of flooding and drought conditions on the emission of volatile organic compounds of Quercus robur and Prunus serotina. Trees-Struct Funct. DOI: $10.1007 /$ s00468-013-0942-5. 
Brehm K. (2004): Erfahrungen mit der Bekämpfung der Spätblühenden Traubenkirsche (Prunus serotina) in Schleswig-Holstein in den Jahren 1977-2004. Schriftenreihe des LANU SH-Natur 10: $66-78$.

Cahill J. F. (1999): Fertilization effects on interactions between above- and belowground competition in an old field. Ecology 80: 466-480.

Claridge K., Franklin S. B. (2002): Compensation and plasticity in an invasive plant species. Biol Invasions 4: 339-347.

Closset-Kopp D., Chabrerie O., Valentin B., Delachapelle H., Decocq G. (2007): When Oskar meets Alice: Does a lack of trade-off in $\mathrm{r} / \mathrm{K}$-strategies make Prunus serotina a successful invader of European forests? For Ecol Manag 247: 120-130.

Closset-Kopp D., Saguez R., Decocq G. (2011): Differential growth patterns and fitness may explain contrasted performances of the invasive Prunus serotina in its exotic range. Biol Invasions 13: 1341-1355.

Coomes D. A., Grubb P. J. (2000): Impacts of root competition in forests and woodlands: a theoretical framework and review of experiments. Ecol Monogr 70: 171-207.

Copolovici L., Niinemets U. (2010): Flooding induced emissions of volatile signalling compounds in three tree species with differing waterlogging tolerance. Plant Cell Environ 33: 1582-1594.

Davidson A., Jennions M., Nicotra A. (2011): Do invasive species show higher phenotypic plasticity than native species and, if so, is it adaptive? A meta-analysis. Ecol Lett 14: 419-431.

Dister E. (1981): Zur Hochwassertoleranz von Auenwaldbäumen in lehmigen Standorten. Verhandlungen der Gesellschaft für Ökologie 10: 325-336.

Donald C. (1958): The interaction of competition for light and for nutrients. Aust J Agric Res 9: 421-35.

Glenz C., Schlaepfer R., Iorgulescu I., Kienast F. (2006): Flooding tolerance of Central European tree and shrub species. For Ecol Manag 235: 1-13.

Godefroid S., Phartyal S., Weyembergh G., Koedam N. (2005): Ecological factors controlling the abundance of non-native invasive black cherry (Prunus serotina) in deciduous forest understory in Belgium. For Ecol Manag 210: 91-105. 
Goldberg D. E. (1990): Components of resource competition in plant communities. In: Grace J. B., Tilman D. (eds) Perspectives on plant competition. Academic Press, San Diego, p. 27-49.

Grime J. (1977): Evidence for the existence of three primary strategies in plants and its relevance to ecological and evolutionary theory. Am Nat 111: 1169-1194.

Grünewald H., Böhm C., Quinkenstein A., Grundmann P., Eberts J., Wühlisch G. (2009): Robinia psendoacacia L.: A lesser known tree species for biomass production. Bioenerg Res 2: 123-133.

Hall T., Smith G. (1955): Effects of flooding on woody plants, West Sandy dewatering project, Kentucky Reservoir. J Forest 53: 281-28.

Holzinger R., Sandoval-Soto L., Rottenberger S., Crutzen P.J., Kesselmeier J. (2000): Emissions of volatile organic compounds from Quercus ilex L. measured by Proton Transfer Reaction Mass Spectrometry under different environmental conditions. J Geophys Res 105: 20573-20579.

Horsley S. B., Gottschalk K. W. (1993): Leaf area and net photosynthesis during development of Prunus serotina seedlings. Tree Physiol 12: 55-69.

Huntley J. (1990): Robinia psendoacacia L. - Black locust. In: Burns R., Honkala B. (eds) Silvics of North America: Volume 2: Hardwoods. United States Government Printing, Washington, p. $755-761$.

Jansen R. M. C., Miebach M., Kleist E., van Henten E. J., Wildt J. (2009): Release of lipoxygenase products and monoterpenes by tomato plants as an indicator of Botrytis cinerea-induced stress. Plant Biol 11: 859-868.

Juhász M., Bagi I., Csintalan Z. (2009): The critical effect of drought stress on the invading features of bird cherry (Prunus serotina Ehrh.) during dispersion stage on a sand-dune area in Hungary. Cereal Res Commun 37: 553-556.

Kowarik I. (2010): Biologische Invasionen: Neophyten und Neozoen in Mitteleuropa. Ulmer, Stuttgart.

Kozlowski T. T. (1997): Responses of woody plants to flooding and salinity. Tree Physiology Monograph 1: 1-29.

Kreuzwieser J., Papadopoulou E., Rennenberg H. (2004): Interaction of flooding with carbon metabolism of forest trees. Plant Biol 6: 299-306. 
Lamb E. G., Kembel S. W., Cahill J. F. (2009): Shoot, but not root, competition reduces community diversity in experimental mesocosms. J Ecol 97: 155-163.

Lehner B., Döll P., Alcamo J., Henrichs T., Kaspar F. (2006): Estimating the impact of global change on flood and drought risks in Europe: a continental, integrated analysis. Climatic Change 75: 273-299.

Loewenstein N., Pallardy S. (1998): Drought tolerance, xylem sap abscisic acid and stomatal conductance during soil drying: a comparison of young plants of four temperate deciduous angiosperms. Tree Physiol 18: 421-430.

Loreto F., Schnitzler J. P. (2010): Abiotic stresses and induced BVOCs. Trends in Plant Science 15: 154-166.

Marquis D. (1990): Prunus serotina Ehrh. - Black cherry. In: Burns R., Honkala B. (eds) Silvics of North America: Volume 2: Hardwoods. United States Government Printing, Washington, p. 594-604.

Martin P. H., Canham C. D., Kobe R. K. (2010): Divergence from the growth-survival trade-off and extreme high growth rates drive patterns of exotic tree invasions in closed-canopy forests. J Ecol 98: 778-789.

McPhee C. S., Aarssen L. W. (2001): The separation of above- and below-ground competition in plants a review and critique of methodology. Plant Ecol 152: 119-36.

Pairon M., Chabrerie O., Casado C. M., Jacquemart A. L. (2006): Sexual regeneration traits linked to black cherry (Prunus serotina Ehrh.) invasiveness. Acta Oecol 30: 238-247.

Pyšek P., Křivánek M., Jarošík V. (2009): Planting intensity, residence time, and species traits determine invasion success of alien woody species. Ecology 90: 2734-2744.

Pyšek P., Richardson D. M. (2007): Traits associated with invasiveness in alien plants: Where do I stand? In: Nentwig W. (ed) Biological Invasions. p. 97-125.

Rajaniemi T., Allison V., Goldberg D. (2003): Root competition can cause a decline in diversity with increased productivity. J Ecol 91: 407-416.

Rédei K., Csiha I., Keserű Z., Kamandiné Végh A., Győri J. (2012): The silviculture of black locust (Robinia psendoacacia L.) in Hungary: a review. SEEFOR 2: 101-107.

Rejmánek M., Richardson D. M. (1996): What attributes make some plant species more invasive? Ecology 77: 1655-1661. 
Rewald B., Leuschner C. (2009): Belowground competition in a broad-leaved temperate mixed forest: pattern analysis and experiments in a four-species stand. Eur J Forest Res 128: 387-398.

Rice S., Westerman B., Federici R. (2004): Impacts of the exotic, nitrogen-fixing black locust (Robinia pseudoacacia) on nitrogen-cycling in a pine-oak ecosystem. Plant Ecol 174: 97-107.

Richards C. L., Bossdorf O., Muth N. Z., Gurevitch J., Pigliucci M. (2006): Jack of all trades, master of some? On the role of phenotypic plasticity in plant invasions. Ecol Lett 9: 981-993.

Robinson D., Hodge A., Griffiths B. S., Fitter A. H. (1999): Plant root proliferation in nitrogenrich patches confers competitive advantage. Proc R Soc B 266: 431-435.

Roloff A., Weisgerber H., Lang U., Stimm B., Schütt B. (1994): Enzyklopädie der Holzgewächse. Handbuch und Atlas der Dendrologie. Wiley-VCH, Weinheim.

Rottenberger S., Kleiss B., Kuhn U., Wolf A., Piedade M. T. F., Junk W., Kesselmeier J. (2008): The effect of flooding on the exchange of the volatile $\mathrm{C}_{2}$-compounds ethanol, acetaldehyde and acetic acid between leaves of Amazonian floodplain tree species and the atmosphere. Biogeosciences 5: 1085-1100.

Sabo A. E. (2000): Robinia pseudoacacia invasions and control in North America and Europe. Restoration and Reclamation Review 6: 1-9.

Sasaki K., Saito T., Lämsä M., Oksman-Caldentey K. M., Suzuki M., Ohyama K., Muranaka T., Ohara K., Yazaki K. (2007): Plants utilize isoprene emission as a thermotolerance mechanism. Plant Cell Physiol 48: 1254-1262.

Shipley B., Meziane D. (2002): The balanced-growth hypothesis and the allometry of leaf and root biomass allocation. Funct Ecol 16: 326-331.

Starfinger U. (1997): Introduction and naturalization of Prunus serotina in Central Europe. In: Brock J. H., Wade M., Pyšek P., Green D. (eds) Plant invasions: Studies from North America and Europe. Backhuys Publishers, Leiden, p. 161-172.

Tilman D. (1982): Resource competition and community structure. Princeton Univ. Pr., Princeton, NJ.

van Kleunen M., Weber E., Fischer M. (2010): A meta-analysis of trait differences between invasive and non-invasive plant species. Ecol Lett 13: 235-245. 
von Holle B., Joseph K. A., Largay E. F., Lohnes R. G. (2006): Facilitations between the introduced nitrogen-fixing tree, Robinia pseudoacacia, and nonnative plant species in the glacial outwash upland ecosystem of Cape Cod, MA. Biodivers Conserv 15: 2197-2215.

Williamson M. H., Fitter A. (1996): The characters of successful invaders. Biol Conserv 78: 163-170. 


\section{Danksagung}

An dieser Stelle möchte ich mich bei den vielen Menschen bedanken, die zum Gelingen der vorliegenden Arbeit beigetragen haben:

Mein besonderer Dank geht an Prof. Christian Ammer für seine Betreuung und Unterstützung während der letzten drei Jahre. Vielen Dank für die zahlreichen Ratschläge, für konstruktive Ideen, für die stets schnelle und kritische Durchsicht meiner Manuskripte und vor allem für das Vertrauen bei der Durchführung der Arbeit.

Bei Prof. Stefan Zerbe möchte ich mich herzlich für die hilfreichen Kommentare zu meinen Manuskripten und für die Übernahme des Koreferats bedanken.

Ein großer Dank geht an Dr. Inga Mölder, die mich bei meiner Arbeit intensiv unterstützt hat und mir auf jede Frage eine Antwort gegeben hat.

Vielen Dank, Peter Annighöfer und André Terwei, für die gemeinsame Arbeit in unserem TicinoProjekt. Ich danke euch nicht nur für die kritische Durchsicht meiner Manuskripte, sondern vor allem auch für die wirklich schöne Zeit mit euch im Ticino, in Bozen und in Göttingen.

Bedanken möchte ich mich auch bei meinen ehemaligen und aktuellen Kollegen aus der Abteilung Waldbau und Waldökologie der gemäßigten Zonen. Ich danke den wissenschaftlichen Mitarbeiter (Dr. Norbert Bartsch, Dr. Peter Schall, und Dr. Torsten Vor) für ihre hilfreichen Ratschläge bezüglich des Versuchsaufbaus und der Datenauswertung. Ich danke den technischen Mitarbeitern (Andrea Bauer, Karl-Heiz Heine, Martina Knaust, Andreas Parth, Heiko Rubbert, Michael Unger und Ulrike Westphal) für ihr Unterstützung bei dem Aufbau, der Betreuung und dem Abbau des Topfversuches sowie bei der Datenaufnahme. Silke Hartmann und Ingrid Helmhold danke ich für die Hilfe und Organisation des Papierkrams. Ein großes Dankeschön geht auch an die anderen Waldbau-Doktoranden und -Post Docs (Katja Albert, Dr. Michaela Dölle, Dr. Steffi Heinrichs, Christina Lödige, Jérôme Metz, Na Lin, Jan Raacke, Dr. Dominik Seidel, Carolin Stiehl und Theresa Waldmann) für die fachlichen, vor allem aber für die nichtfachlichen Gespräche, Doktorandentreffen und gemeinsame Unternehmungen. Vor allem aber danke ich euch dafür, dass ihr mir immer geholfen habt, wenn ich mal wieder viele kräftige Hände für meinen Topfversuch brauchte. Resa, dir danke ich ganz besonders für den Vorrat an Nervennahrung!

Ich danke JProf. Boris Bonn, Efstratios Bourtsoukidis und Dominika Radacki für die nette und produktive Zusammenarbeit beim VOC-Versuch. 
Vielen Dank an meine Hiwis, die bei dem Aufbau und dem Abbau des Topfversuches geholfen haben. Vielen Dank auch an das Team des Forstbotanischen Gartens unter der Leitung von Volker Meng für die Unterstützung beim Rasenmähen und anderen Maßnahmen, bei denen schweres Gerät vonnöten war. Ich danke den Mitarbeitern der Zentralgärtnerei für die massenhafte Herbstlaub-Anlieferung um meine Töpfe winterfest zu machen.

Vielen Dank auch an Dieter Nünchert, für seine technischen Ratschläge und für seine Unterstützung bei umfangreichen Sägearbeiten.

Ich bedanke mich bei der Marianne und Dr. Fritz Walter Fischer-Stiftung innerhalb des Stifterverbandes für die Deutsche Wissenschaft für die Finanzierung des Projektes. Frau Fischer, herzlichen Dank, dass Sie sich immer für unsere Arbeit interessiert haben.

Armin, vielen Dank dafür, dass du mich immer wieder aufgebaut und motiviert hast. Vielen Dank für dein logisches Nachdenken über meinen Versuch und für die tatkräftige Unterstützung beim Bauen, Pflanzen, Gießen, Messen, Ernten... Du bist der Beste!

Ein letztes Dankeschön geht an meine Eltern und meine Schwestern nicht nur für die Unterstützung, sondern vor allem auch für die Ablenkung von der Arbeit durch die vielen wissenschaftsfernen Gespräche und Unternehmungen. 


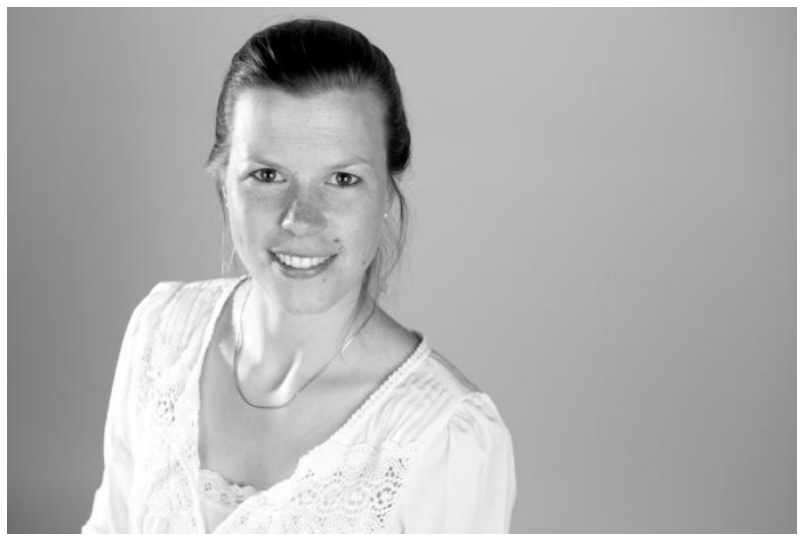

\section{Curriculum vitae}

\section{Personal information}

\begin{tabular}{ll}
\hline Name & Heike Kawaletz \\
Date of birth & 15.12 .1983 \\
Place of birth & Salzgitter (Germany) \\
Nationality & German
\end{tabular}

\section{Education}

\begin{tabular}{|c|c|}
\hline \multirow{2}{*}{ 01/2010-08/2013 } & PhD program 'Forest Science and Forest Ecology' \\
\hline & Georg-August-University, Göttingen \\
\hline \multirow{2}{*}{$10 / 2006-08 / 2009$} & Master program 'Nature Conservation and Forest Ecology’ (M. Sc.) \\
\hline & Georg-August-University, Göttingen \\
\hline 03/2007-08/2007 & Stay abroad at the Universidad Austral de Chile, Valdivia (Chile) \\
\hline \multirow{2}{*}{$10 / 2003-09 / 2006$} & Bachelor program 'Forestry and Forest Ecology' (B. Sc.) \\
\hline & Georg-August-University, Göttingen \\
\hline
\end{tabular}

\section{Scientific work experience}

since $08 / 2013$

$11 / 2009-08 / 2013$

09/2009-10/2009

$10 / 2006-03 / 2007$
Scientific research assistant at the Thünen Institute of International Forestry and Forest Economics, Hamburg

Scientific research assistant at the Department of Silviculture \& Forest Ecology of the temperate Zones, Georg-August-University, Göttingen Assistant at the Northwest German Forest Research Station, Göttingen Student assistant at the Department of Forest Botany and Tree Physiology, Georg-August-University, Göttingen 


\section{Publication list}

\section{Journal articles}

Kawaletz H., Mölder I., Annighöfer P., Terwei A., Zerbe S., Ammer C. (2013): Back to the roots: how do seedlings of native tree species react to the competition by exotic species? Annals of Forest Science. DOI: 10.1007/s13595-013-0347-z.

Bourtsoukidis E., Kawaletz H., Radacki D., Schütz S., Hakola H., Hellén H., Noe S., Mölder I., Ammer C., Bonn B. (2013): Impact of flooding and drought conditions on the emission of volatile organic compounds of Quercus robur and Prunus serotina. Trees-Struct Funct. DOI: 10.1007/s00468-013-0942-5.

Skowronek S., Terwei A., Zerbe S., Mölder I., Annighöfer P., Kawaletz H., Ammer C. (2013): Regeneration potential of floodplain forests under the influence of non-native tree species - soil seed bank analysis in Northern Italy. Restoration Ecology, DOI: 10.1111/rec.12027.

Terwei A., Zerbe S., Zeileis A., Annighöfer P., Kawaletz H., Mölder I., Ammer C. (2013): Which are the driving factors for tree regeneration in North Italian floodplain forests invaded by non-native tree species? Forest Ecology and Management 304: 192-203.

Kawaletz H., Mölder I., Zerbe S., Annighöfer P., Terwei A., Ammer C. (2013): Exotic tree seedlings are much more competitive than natives but show underyielding when growing together. Journal of Plant Ecology 6 (4): 305-315.

Annighöfer P., Mölder I., Zerbe S., Kawaletz H., Terwei A., Ammer C. (2012a): Biomass functions for the two alien tree species Prunus serotina Ehrh. and Robinia pseudoacacia L. in floodplain forests of Northern Italy. European Journal of Forest Research 131: 1619-1635.

Annighöfer P., Schall P., Kawaletz H., Mölder I., Terwei A., Zerbe S., Ammer C. (2012b): Vegetative growth response of black cherry (Prunus serotina) to different mechanical control methods in a biosphere reserve. Canadian Journal of Forest Research 42: 2037-2051.

\section{Submitted manuscripts}

Kawaletz H., Mölder I., Annighöfer P., Terwei A., Zerbe S., Ammer C.: Pot experiments with woody species - a review. Revised version submitted to Forestry.

Annighöfer P., Kawaletz H., Mölder I., Terwei A., Zerbe S., Ammer C.: Using black cherry (Prunus serotina Ehrh.) - A model approach how to cope with an invasive alien species. Submitted to Annals of Forest Science. 